Universidade DE SÃo PAUlo

Faculdade de Filosofia, Letras e Ciências Humanas

DEPARTAMENTO DE Linguística

Programa de Pós-graduação em Semiótica e Linguística Geral

Infinitivo flexionado em português brasileiro:

Frequência e percepções sociolinguísticas

\author{
FERnanda CANever
}

Versão Corrigida

São Paulo

2017 


\author{
Universidade de São Paulo \\ Faculdade de Filosofia, Letras e Ciências Humanas \\ Departamento de Linguística \\ Programa de Pós-graduaÇão em Semiótica e \\ LinguísticA GERAL
}

\title{
Infinitivo flexionado em português brasileiro: Frequência e percepções sociolinguísticas
}

\author{
Fernanda Canever
}

Tese apresentada ao Programa de PósGraduação em Semiótica e Linguística Geral do Departamento de Linguística da Faculdade de Filosofia, Letras e Ciências Humanas da Universidade de São Paulo para a obtenção do título de Doutor em Letras.

Orientador: Prof. Dr. Ronald Beline Mendes

Versão Corrigida

São Paulo

2017 


\section{Agradecimentos}

Agradeço aos meus pais, Ricardo e Maria Luísa, aos meus irmãos, Ricardo Canever Filho e Rafael Canever, ao meu avô, João Andrade, ao Anderson, meu noivo, e à Nena, amiga querida, por tudo que fazem por mim, sempre. Agradeço também à Zara por ser minha companheira de todas as horas.

Agradeço ao meu orientador, Ronald Beline Mendes, por ter, na minha primeira aula do curso de Letras, em 2003, despertado em mim o gosto pela Linguística e, especialmente, pela orientação nos últimos anos. Esta tese não teria sido finalizada sem o seu apoio.

Agradeço à Fabiola Boschetti, ao Dr. Romildo e ao Dr. André Guerrero pela ajuda com as questões de saúde que enfrentei nos últimos anos.

Agradeço ao professor Eckhard Bick por ter me ajudado com a etiquetagem do corpus. Sem a sua colaboração, eu não teria conseguido trabalhar com tantos dados.

Agradeço à professora Evani Viotti pela orientação nos primeiros anos desta pesquisa e às professoras Esmeralda Negrão e Heliana Mello pelas contribuições no exame de qualificação.

Agradeço aos professores Sherman Wilcox, William Croft e Jill Morford por terem me acolhido na UNM e por me ajudarem tanto, mesmo que à distância, até hoje. Sempre que volto, me sinto em casa. Ao professor Stefan Th. Gries, da Universidade da Califórnia em Santa Barbara, agradeço por ter me recebido para o estágio acadêmico em 2014.

À professora Thaïs Cristófaro, ao professor Marcos Lopes e ao professor Paulo Chagas, agradeço pelo apoio em momentos que estive desiludida com a vida acadêmica.

Agradeço a todos os colegas do GESOL, aos colegas do LLIC e a todos 
os colegas da Letras e da Linguística com quem convivi nos últimos 14 anos. Agradeço, especialmente, à Livia Oushiro, pelas conversas e pela inspiração que sempre foi para mim. Agradeço à Janayna Carvalho, à Aline Benevides e ao João Paulo da Silva pela amizade e carinho.

Agradeço ao Programa de Pós-graduação em Linguística da USP pelo financiamento da licença de uso da plataforma Qualtrics para a aplicação dos questionários online.

Agradeço à Erica, ao Robson e à Denise, pelo carinho, pela ajuda sempre que eu precisei e pela paciência. Pelo financiamento desta pesquisa, agradeço à Capes. 


\section{Resumo}

Tomando como objeto o emprego variável da flexão do infinitivo (INF) no português brasileiro (PB), este estudo tem dois interesses centrais: (i) analisar se o emprego da forma flexionada (INFflex) está aumentando nos três contextos sintáticos opcionais "originais" (Bossaglia, 2013a) - orações adverbiais, complementos oracionais de nomes e complementos oracionais de adjetivos e (ii) investigar se valores sociais positivos, tais como o prestígio geralmente associado à concordância verbal em PB (Mendes \& Oushiro, 2015; Naro \& Scherre, 1991; Rubio \& Gonçalves, 2012; Scherre \& Naro, 2014, 2006), estariam sendo atribuídos a INFflex.

Para investigar a primeira hipótese, analisa-se quantitativamente o emprego de INFflex em um corpus formado por 1346 teses produzidas por alunos de diferentes unidades da USP entre 1995 e 2014. Quanto à segunda, busca-se, por meio de um estudo de percepção sociolinguística que se desenvolveu com base na técnica de estímulos pareados (Campbell-Kibler, 2008; Labov et al., 2006; Mendes, 2016b; Oushiro, 2015) verificar se falantes são "julgados" como "mais inteligentes", "mais escolarizados" e "mais formais" na presença de INFflex.

Os resultados da análise dos dados de produção demonstram que, ao contrário do que se esperava, INFflex não está aumentando na escrita acadêmica. Por outro lado, verificaram-se taxas altas de INFflex com o verbo ser - independentemente do contexto sintático e da pessoa verbal -, em orações adverbiais antepostas à oração principal e com as preposições/locuções prepositivas antes de, ao, após, depois de e por. No que diz respeito à distribuição de INFflex de acordo com a área do conhecimento, verificaram-se maiores proporções de INFflex nas orações adverbiais em teses da área de 
Humanas.

O teste de percepção, por sua vez, revelou que, em contextos sintáticos nos quais o emprego de INFflex é considerado opcional, não houve diferença significativa na forma como as "vozes" foram julgadas; porém, em contextos sintáticos nos quais flexionar o infinitivo é considerado um "erro" do ponto de vista prescritivo, a presença de INFflex levou a percepções de menor "inteligência", menor "escolaridade" e menor "formalidade". Especificamente no caso dos contextos não padrão, verificou-se, ainda, um efeito significativo da variável Idade do participante: as percepções dos participantes mais jovens foram mais "neutras", ao passo que as respostas dos acima de 50 anos foram mais polarizadas: quanto mais velhos, mais negativamente julgaram versões com INFflex e mais positivamente versões com INFØ. Tais resultados sugerem que falantes mais jovens percebem com mais naturalidade usos hipercorrigidos de INFflex. 


\section{Abstract}

Focusing on the variable use of inflected infinitives (INF) in Brazilian Portuguese (BP), the goal of this study is twofold: (i) to investigate if the use of the inflected variant (INFflex) is increasing in three "originally" optional syntactic contexts (Bossaglia, 2013a:27) - adverbial clauses, noun complements and adjective complements - and (ii) to investigate if positive social values, such as the prestige usually associated with verbal agreement in BP (Mendes \& Oushiro, 2015; Naro \& Scherre, 1991; Rubio \& Gonçalves, 2012; Scherre \& Naro, 2014, 2006), are being assigned to INFflex.

To test the first hypothesis, the use of INFflex is analyzed in a corpus of 1.346 theses written by USP graduate students from different areas of knowledge from 1995 to 2014. As for the second hypothesis, a matched-guise experiment was conducted (Campbell-Kibler, 2008; Lambert et al., 1960; Mendes, 2016a; Oushiro, 2015) to test if speakers are perceived as "more intelligent", "more educated" and "more formal" when heard using the INFflex guises.

Contradicting the study's hypothesis, production data show no increase in the use of INFflex in academic writing. However, high rates of INFflex were attested with the verb be - regardless of the syntactic contexts and grammatical person -, in preposed adverbial clauses and with the prepositions antes de, ao, após, depois de and por. As for the area of knowledge, higher rates of INFflex in adverbial clauses were attested in Human Sciences theses. Perception data show no difference in how the voices were perceived when INFflex was used in adverbial clauses. On the other hand, voices were perceived as "less intelligent", "less educated" and "less formal" when INFflex was used in hypercorrect contexts, as expected. In addition, a significant age 
effect was found in hypercorrect contexts: the older participants, the more negatively they perceived the INFflex guises and the more positively they perceived the non-inflected (INF $\varnothing$ ) guises. These results suggest that younger speakers perceive hypercorrect use of INFflex as more natural. 


\section{Sumário}

Lista de Tabelas $\quad$ xiii

Lista de Figuras $\quad$ Xv

$\begin{array}{lr}\text { Introdução } & 1\end{array}$

1 Infinitivo flexionado: o estado da arte $\quad 6$

1.1 Consensos . . . . . . . . . . . . . . . . . . . . . . . 8

1.1.1 Quando "se deve" usar INFflex . . . . . . . . . . 9

1.1.2 Quando "não se deve" usar INFflex . . . . . . . . . . . 9

1.1.3 Quando o uso de INFflex é "opcional" . . . . . . . . . 11

1.2 Dissensos . . . . . . . . . . . . . . . . . . . . . 12

1.3 A visão de Maurer Jr. . . . . . . . . . . . . . . . . . . . . . . 15

1.4 Estudos empíricos sobre INFflex . . . . . . . . . . . . . . 19

1.4.1 INFflex em português brasileiro: textos jornalísticos . . 19

1.4.2 INFflex em português brasileiro: textos acadêmicos . . 21

1.4.3 INFlex em português europeu: orações adverbiais . . . 23

1.4.4 INFflex em português europeu: construções causativas e perceptivas . . . . . . . . . . . . . 26

1.5 Síntese . . . . . . . . . . . . . . . . . . . 28

2 Pressupostos teóricos $\quad 29$

2.1 Proposta . . . . . . . . . . . . . . . . . . . . . . . 29

2.2 Sociolínguistica e modelos baseados no uso . . . . . . . . . . . 31

2.3 Síntese . . . . . . . . . . . . . . . . . . . . 48 
3 Materiais e Métodos $\quad 49$

3.1 Construindo o Corpus Pós_USP . . . . . . . . . . . . . . . 49

3.2 Etiquetagem do corpus . . . . . . . . . . . . . . . . . 52

3.3 Extração dos dados . . . . . . . . . . . . . . . . . . . 55

3.4 Revisão qualitativa dos dados . . . . . . . . . . . . . 57

3.5 Codificação dos dados e variáveis independentes . . . . . . . . 62

3.6 Síntese . . . . . . . . . . . . . . . . . . . 64

4 INFflex ao longo de 20 anos na redação acadêmica $\quad 65$

4.1 Distribuição dos dados . . . . . . . . . . . . . . . . 66

4.1 Dados gerais . . . . . . . . . . . . . . 66

4.1 .2 Orações adverbiais . . . . . . . . . . . . . . . 71

4.1.3 Complementos de adjetivos . . . . . . . . . . 76

4.1.4 Complementos de substantivos . . . . . . . . . . 77

4.2 Análises multivariadas . . . . . . . . . . . . . . . . 80

4.2.1 Modelagem GLMM: Orações adverbiais . . . . . . . . . 81

4.2.2 Modelagem GLMM: Complementos de adjetivos . . . . 85

4.2.3 Modelagem GLMM: Complementos de substantivos . . 87

4.3 Síntese . . . . . . . . . . . . . . . . . . . . . 88

5 Estudo de percepção $\quad 90$

5.1 Desenho do experimento . . . . . . . . . . . . . . . . . 92

5.1.1 Preparação dos estímulos auditivos . . . . . . . . . . 92

5.1.2 Formação dos conjuntos de estímulos . . . . . . . . . . 94

5.1 .3 Aplicação dos questionários . . . . . . . . . . . . . . . 95

5.2 Análise dos dados . . . . . . . . . . . . . . . . . . . . . . . 99

5.3 Discussão . . . . . . . . . . . . . . . . . . . . . . . . 104

5.4 Síntese . . . . . . . . . . . . . . . . . . 105

$\begin{array}{ll}\text { Referências } & 110\end{array}$

Anexo A - Análise descritiva das variáveis do estudo 119

Anexo B - Questionários do teste de percepção 125 


\section{Lista de Tabelas}

1.1 Efeitos esperados das variáveis testadas por Vanderschueren \& de Cuypere (2014) . . . . . . . . . . . . . . . . . . . 25

3.1 Corpus Pós_USP: Número de teses por áreas, unidades e anos 52

3.2 Total de infinitivos extraídos do corpus . . . . . . . . . . . 55

3.3 Total de dados por contexto sintático antes da revisão . . . . . 57

3.4 Total de dados por contexto sintático depois da revisão . . . 62

4.1 Distribuição geral dos dados . . . . . . . . . . . . . . 66

4.2 Distribuição de INFflex por contexto sintático . . . . . . . . . . . 67

4.3 Análise descritiva do cruzamento das variáveis pessoa verbal e posição das adverbiais . . . . . . . . . . . . . . . 74

4.4 Modelo Logístico com efeitos mistos para INFflex em adverbiais 81

4.5 Modelo Logístico com efeitos mistos para INFflex em adverbiais, considerando interação entre Posição e Pessoa Verbal . . . . . 84

4.6 Modelo Logístico com efeitos mistos para INFflex em complementos de adjetivos . . . . . . . . . . . . . . . 85

4.7 Modelo Logístico com efeitos mistos para INFflex em complementos de substantivos . . . . . . . . . . . . . 87

5.1 Distribuição dos 411 participantes de acordo com o local em que residem . . . . . . . . . . . . . . . . . . . . 98

5.2 Distribuição dos 411 participantes de acordo com seu nível de escolaridade . . . . . . . . . . . . . . . . . . . . 9 98 
5.3 Carga fatorial de 5 escalas perceptuais (Método: Análise de componentes principais com rotação varimax) . . . . . . . . 100

5.4 Resultados de um modelo de regressão linear com efeitos mistos para 'percepção de competência' . . . . . . . . . . . . . . . . 101

A1 Análise descritiva de INFflex de acordo com as variáveis independentes do estudo . . . . . . . . . . . . . . . . . . . . 119

A2 Análise descritiva da interação entre as variáveis Pessoa Verbal e Ano . . . . . . . . . . . . . . . . . . . 120

A3 Análise descritiva da interação entre as variáveis Verbo e Ano 121

A4 Análise descritiva da interação entre a variável Contexto Sintático e Ano . . . . . . . . . . . . . . . . . . 122

A5 Análise descritiva da interação entre as variáveis Preposição e Posição: Orações adverbiais . . . . . . . . . . . . . . . . 124 


\section{Lista de Figuras}

2.1 Uma gramática baseada no uso segundo Kemmer \& Israel (1994) 33

2.2 Adaptação do diagrama de Kemmer \& Israel (1994) apresentada por Canever (2012) . . . . . . . . . . . . . . . 34

2.3 Trajetória da evolução das variantes de futuro no português brasileiro. Extraído de Blythe \& Croft (2012)) . . . . . . . . . 42

3.1 Arquitetura do Corpus Pós_USP . . . . . . . . . . . . . 50

3.2 Exemplo da codificação dos arquivos que compõem o Corpus Pós_USP . . . . . . . . . . . . . . . . . 51

3.3 Texto do exemplo 1 etiquetado pelo PALAVRAS . . . . . . . . 54

4.1 Distribuição de INFflex por contexto sintático . . . . . . . . . 67

4.2 Distribuição de INFflex por faculdade . . . . . . . . . . . . . 68

4.3 Distribuição de INFflex por área e por sexo do autor . . . . . 68

4.4 Distribuição de INFflex ao longo de 20 anos . . . . . . . . . . 69

4.5 Distribuição de INFflex por pessoa verbal ao longo de 20 anos 70

4.6 Distribuição de INFflex por tipo de verbo ao longo de 20 anos 70

4.7 Distribuição de INFflex por contexto sintático ao longo de 20 anos ............................... 71

4.8 Distribuição de INFflex em orações adverbiais por preposição . 72

4.9 Distribuição de INFflex em orações adverbiais por preposição ao longo de 20 anos . . . . . . . . . . . . . . . . . . . 72

4.10 Distribuição de INFflex pela posição das orações adverbiais . 73

4.11 Distribuição de INFflex de acordo com a posição das orações adverbiais e da preposições . . . . . . . . . . . . . . . . . 74 
4.12 Distribuição de INFflex pela posição da adverbial e pela pessoa verbal . . . . . . . . . . . . . . . . 75

4.13 Distribuição de INFflex em complementos de adjetivos por pessoa verbal e por verbo . . . . . . . . . . . 76

4.14 Distribuição de INFflex em complementos de adjetivos por verbo ao longo de 20 anos . . . . . . . . . . . . . . . 77

4.15 Distribuição de INFflex em complementos de substantivo por Unidade da USP. . . . . . . . . . . . . . . . . . . . . . . 78

4.16 Distribuição de INFflex em complemento de substantivos por Área do conhecimento . . . . . . . . . . . . . . 78

4.17 Distribuição de INFflex em complementos de substantivo por verbo e por pessoa verbal . . . . . . . . . . . . . . . . 79

4.18 Efeitos aleatórios de Preposição (Adverbiais) . . . . . . . . . . 83

4.19 Efeitos aleatórios de adjetivos . . . . . . . . . . . . 86

4.20 Efeitos aleatórios de substantivos . . . . . . . . . . . . 88

5.1 Tela do Praat com exemplo de flexão. . . . . . . . . . . . . . . 93

5.2 Tela de apresentação da pesquisa. . . . . . . . . . . . . . . . . 96

5.3 Tela de apresentação dos áudios e de um trecho do questionário com as escalas . . . . . . . . . . . . . . . . . . . 9 96

5.4 Total de participantes que completaram do experimento (411) para cada conjunto de dados que ouviram. . . . . . . . . . . 99

5.5 Percepção de 'competência' de acordo com INFflex x INFØ . . 101

5.6 Percepção de 'competência' de acordo com INFflex x INFØ nos dois contextos sintáticos . . . . . . . . . . . . 102

5.7 'Percepção de competência' de acordo com INFflex x INFØ em complemento de verbo modal e de acordo com a idade dos participantes . . . . . . . . . . . . . . . . . 103

5.8 Percepção de 'competência' de cada voz de acordo com INFflex

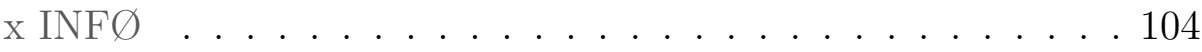

9 Questionário do teste de percepção . . . . . . . . . . . . 125 


\section{Introdução}

A possibilidade de flexionar o infinitivo é considerada uma "anomalia" das línguas românicas (Scida, 2004). ${ }^{1}$ No caso do português, especificamente, Almeida (1981:150) acredita que "a conjugação do infinitivo é a maior prova de putrefação do nosso idioma". Maurer Jr. (1968:100), por outro lado, vê com naturalidade a "criação" de um infinitivo flexionado na área lusitana, o que, segundo ele, teria acontecido a partir do infinitivo românico comum por influência da semelhança formal com o subjuntivo futuro. Por analogia, os falantes teriam transferido para o infinitivo as flexões do futuro do subjuntivo nos verbos regulares, constituindo, assim, as formas flexionadas: termos nós, terem eles, terdes vós (Maurer Jr., 1968:68). Nesse sentido, Bossaglia $(2013 a: 27)$ afirma que "os loci relevantes para a origem do infinitivo flexionado" são as orações adverbiais introduzidas por preposição (1 e 2), os complementos oracionais de substantivos (3) e os complementos oracionais de adjetivos (4), contextos sintáticos que também estão entre aqueles que Maurer Jr. (1968) chama de "facultativos":

(1) Viemos cedo, por estar(mos) ansiosos de conhecer os resultados. ${ }^{2}$

(2) Ao saber(em) da notícia, ficaram apavorados.

(3) Eles têm a vantagem de conhecer(em) bem o grego e o latim.

1 Segundo Scida (2004), a flexão do infinitivo é possível em português, no galego, no mirandês, no sardo, no napolitano antigo e no leonês antigo.

2 Os exemplos de 1-4 são de Maurer Jr. (1968). 
(4) Estes, certos de ter(em) assegurado a vitória, tornaram-se negligentes e descuidados.

Nesses casos, o fato de que tanto o infinitivo flexionado quanto o não flexionado são possíveis e atestados no uso permite que essas formas - que daqui em diante vão ser chamadas, respectivamente, de INFflex e INFØ - sejam tratadas como variantes da variável (INF), no sentido laboviano de "duas maneiras de se dizer a mesma coisa" (Labov, 1969). Nos exemplos 1 - 4, nos quais as duas variantes são consideradas prescritivamente corretas (Bechara, 2009; Cunha \& Cintra, 2013; Lima, 2017 [1957]; Said Ali, 1966), considera-se que a opção pelo emprego de INFflex depende do "intuito ou necessidade de pormos em evidência o agente do verbo" (Said Ali, [s/d.] :246).

Além de exemplos como esses, nos quais o emprego de INFflex é considerado "facultativo" tanto por Maurer Jr. (1968) quanto por gramáticos (Bechara, 2004; Cunha \& Cintra, 2013; Lima, 2017 [1957]; Said Ali, 1966), são atestadas em português brasileiro (PB) ocorrências de INFflex em contextos sintáticos que gramáticos consideram não padrão:

(5) O problema de toda análise semiótica ou gestalt é que, se tomarmos o objeto de forma isolada, todas as análises podem se cancelarem como meras interpretações subjetivas. $(8 \text { mai14 })^{3}$

(6) Queiram, portanto, por recomendação da Direção, estarem disponíveis nessas datas. (24set15)

(7) Fiz a separação das disciplinas que precisam serem abertas somente para defasados. (22mar17)

Extraídos de um artigo científico (5) e de e-mails intitucionais (6 e 7), esses exemplos, produzidos na linguagem escrita formal, permitem supor que os autores tinham o objetivo de empregar a forma padrão quando flexionaram os infinitivos "além da conta".

Em um estudo exploratório (Gries, 2013) motivado por ocorrências como 5-7, Canever (2012) aventou as hipóteses (i) de que tais usos - que considerou

3 Tais exemplos foram coletados por professores universitários e enviados a mim nas datas indicadas. 
exemplos de hipercorreção (Labov, 1972) - poderiam ser indícios de uma preferência por INFflex nos contextos sintáticos considerados opcionais e (ii) de que valores sociais positivos, possivelmente relacionados a prestígio - no sentido de que concordar é, em geral, mais prestigioso que não concordar -, estariam sendo associados à variante flexionada. Inspirada pela visão de Maurer Jr. (1968: 100), que afirma que, uma vez "criada" a forma flexionada, "nota-se uma tendência para alargar sempre mais o seu emprego", Canever (2012) testou a primeira hipótese e analisou o emprego variável de INFflex em um corpus de 180 teses produzidas por alunos da área de Letras da FFLCH$\mathrm{USP}^{4}$. Dentre os resultados a que chegou, destacam-se aqueles relativos aos contextos sintáticos nos quais, segundo Bossaglia (2013a), teria se iniciado a variação: $75 \%$ de INFflex em orações adverbiais $(\mathrm{N}=525), 53,5 \%$ de INFflex em complementos de adjetivos $(\mathrm{N}=101)$ e $94,5 \%$ de INFflex em complementos de nomes $(\mathrm{N}=54)$. No que diz respeito aos usos hipercorrigidos, tais como 5-7 - contextos não padrão de acordo com a visão prescritivista - Canever (2012) encontrou $0.3 \%$ de INFflex $(\mathrm{N}=353)$.

Partindo desses resultados, esta tese se propõe a analisar se o emprego de INFflex está aumentando nos três contextos "originais" de variação orações adverbiais, complementos de nomes e complementos de adjetivos -, nos quais Canever (2012) encontrou uma alta frequência de INFflex na escrita padrão. Para tal fim, construiu-se o Corpus Pós_Usp, formado por 1346 teses produzidas por alunos de diferentes unidades da USP entre os anos de 1995 e 2014. O principal interesse na constituição dessa amostra de teses está no teste da hipótese sobre o aumento na taxa de ocorrência de INFflex nos contextos opcionais "originais" (Bossaglia, 2013a) em um período de 20 anos, o que não foi feito em Canever (2012). Essa nova amostra permite, ainda, verificar diferenças nas tendências de emprego de INFflex entre alunos de diferentes áreas do conhecimento. Considerando-se que os resultados a que Canever (2012) chegou dizem respeito apenas à escrita de alunos de Letras, cujo objeto de estudo é a língua, interessa investigar em que medida tais resultados se mantêm para alunos de outras áreas.

Além do interesse na produção acadêmica, este estudo investiga, por meio

4 Faculdade de Filosofia, Letras e Ciências Humanas da USP. 
de um experimento de percepção sociolinguística, se falantes são percebidos como "mais inteligentes", "mais escolarizados" e "mais formais" quando empregam INFflex. Busca-se, por meio desse estudo de percepção, testar a hipótese de que valores sociais positivos, tais como o prestígio geralmente associado à concordância verbal em PB (Mendes \& Oushiro, 2015; Naro \& Scherre, 1991; Scherre \& Naro, 2014, 2006), estariam sendo atribuídos a INFflex, hipótese já aventada em Canever (2012).

Esta tese, portanto, tem dois interesses centrais (i) analisar quantitativamente o emprego de INFflex em contextos opcionais na escrita padrão entre os anos de 1995 e 2014, e (ii) investigar se significados sociais positivos são associados a INFflex. Pretende-se, com isso, contribuir com a descrição do padrão atual em PB e lançar luz a questões relacionadas ao processo de hipercorreção de INFflex, atualmente em curso em PB e ilustrado nos exemplos 5-7.

Sendo assim, esta tese organiza-se do seguinte modo: no capítulo 1, apresenta-se uma revisão da literatura sobre INFflex, que aborda (i) consensos e dissensos entre os gramáticos, (ii) a visão de Maurer Jr. (1968:100), para quem o emprego de INFflex em PB só tende a aumentar, e (iii) estudos sobre o emprego variável de INFflex na escrita padrão em PB e em português europeu (PE).

No capítulo 2, estabelecem-se as bases teóricas deste estudo, que é, essencialmente, variacionista. Descreve-se a visão de língua das teorias de língua baseadas no uso, nas quais a frequência de uso desempenha um papel central na contínua atualização da gramática. Apresentam-se, também, estudos de variação e mudança linguística feitos à luz dessas teorias, que demonstram, por meio de modelos matemáticos, que tanto a frequência de uso quanto a valoração social das variantes linguísticas são essenciais em processos de propagação de usos inovadores. Discutem-se, ainda, estudos sobre o fenômeno da hipercorreção no inglês bem como estudos sobre a concordância verbal em $\mathrm{PB}$, cujos resultados são relevantes para o estudo do emprego variável de INFflex.

Questões relacionadas ao levantamento e tratamento dos dados são abordadas no capítulo 3. Descreve-se o processo de arquitetura e construção 
do Corpus Pós_Usp, que possui aproximadamente 90 milhões de palavras e que foi etiquetado por meio do analisador sintático PALAVRAS (Bick, 2000). Embora a etiquetagem tenha sido indispensável para as extrações de infinitivos de primeira e terceira pessoa do plural (1PP e 3PP), foi necessário fazer uma revisão qualitativa de 61.444 dados de infinitivo extraídos a partir das etiquetas gramaticais. Discute-se como foi feita a revisão e, então, a codificação dos dados de acordo com as variáveis independentes deste estudo: Ano, Área do Conhecimento, Unidade da USP, Arquivo, Autor, Sexo do Autor, Contexto Sintático, Pessoa Verbal e Verbo.

O capítulo 4 apresenta os resultados das análises dos dados. Primeiramente, apresentam-se análises descritivas, feitas com o conjunto total de dados. Essas análises mostram a distribuição geral das ocorrências de INFflex de acordo com as variáveis independentes, algumas, inclusive, em interação com a variável Ano. Analisam-se, por exemplo, as proporções de emprego de INFflex nos três contextos sintáticos ao longo dos anos (Contexto Sintático x Ano). Apresentam-se, então, os resultados das análises multivariadas, realizadas separadamente para cada um dos contextos sintáticos investigados.

Por fim, no capítulo 5, apresenta-se o experimento de percepção sociolinguística, que revela uma diferença na percepção por parte de ouvintes mais velhos e mais novos no que diz respeito a usos hipercorrigidos, tais como o emprego de INFflex em complementos de verbos auxiliares. Na sequência desse último capítulo, faz-se um balanço conclusivo dos resultados desses dois conjuntos de análise: a frequência de INFflex ao longo de 20 anos em teses da USP e a percepção sociolinguística associada à variável (INF). 


\title{
1 \\ Infinitivo flexionado: o estado da arte
}

A flexão do infinitivo em português constitui um desafio para aqueles que buscam regular seu uso. No intuito de prescrever regras, nas quais se baseia a popular distinção entre o "certo" e o "errado" na língua, certos gramáticos admitem tratar-se de uma questão "desconcertante", "escabrosa", "árida e árdua" (Almeida, 2009 [1943] : 541). Segundo Rocha Lima, "até hoje não foi possível aos gramáticos formular um conjunto de regras fixas, pelas quais se regesse o emprego de uma ou de outra forma" (Lima, 2017 [1957] : 502). Nessa mesma linha, declaram Cunha \& Cintra (2013 : 499):

\begin{abstract}
"O emprego das formas flexionada e não flexionada do INFINITIVO é uma das questões mais controvertidas da sintaxe portuguesa. Numerosas têm sido as regras propostas pelos gramáticos para orientar com precisão o uso seletivo das duas formas. Quase todas, porém, submetidas a um exame mais acurado, revelaram-se insuficientes ou irreais. Em verdade, os escritores das diversas fases da língua portuguesa nunca se pautaram, no caso, por exclusivas razões de lógica gramatical, mas se viram sempre, no ato da escolha, influenciados por ponderáveis motivos de ordem estilística, tais como o ritmo da frase, a ênfase do enunciado, a clareza da expressão. Por tudo isso, parece-nos mais acertado falar não de regras, mas de tendências que se observam, no emprego de uma e de outra forma do INFINITIVO."
\end{abstract}

À parte de alguns poucos contextos para os quais são apresentadas regras ou "conselhos", na maioria dos casos atribui-se ao próprio falante a decisão por 
flexionar ou não o infinitivo, podendo-se optar pela flexão por razões de clareza, para evitar confusão ou simplesmente porque se deseja colocar em evidência o agente da ação (Bechara, 2009; Cegalla, 2008; Cipro Neto \& Infante, 2010; Cunha \& Cintra, 2013; Lima, 2017 [1957]; Said Ali, 1966). São inúmeros os normativistas que, ao apresentar fatores de natureza subjetiva, conferem ao falante grande liberdade de escolha. Bechara (2004:286) apresenta os seguintes exemplos ao comentar casos nos quais o emprego de INFØ "revela que nossa atenção se volta com especial atenção para a ação verbal" (1) enquanto o emprego de INFflex "serve de insistir na pessoa do sujeito" (2):

(1) Estudamos para vencer na vida.

(2) Estudamos para vencermos na vida.

Nessas orações reduzidas de infinitivo cujo sujeito é o mesmo da oração anterior, embora Cipro Neto \& Infante (2010 : 489) considerem "desnecessário" o emprego de INFflex, ele se justifica, segundo esses gramáticos, "se existir a intenção e a necessidade de enfatizar o agente do processo expresso pelo infinitivo".

Diante dessa realidade, interessa investigar como se comportam falantes que procuram usar a norma padrão e se deparam com contextos sintáticos nos quais tanto a forma flexionada quanto a não flexionada do infinitivo são abonadas por gramáticos como Said Ali (1966), Lima (2017 [1957]), Cunha \& Cintra (2013) e Bechara (2009). Nesse sentido, ao revelar tendências que se observam na escrita de falantes altamente escolarizados em um estilo de alto grau de automonitoramento - a redação de teses e dissertações -, a investigação apresentada nesta tese contribui para a descrição do padrão brasileiro moderno no que concerne a usos opcionais do infinitivo flexionado (INFflex).

Antes de apresentar estudos recentes que focalizam esse fenômeno linguístico empiricamente (1.4), este capítulo traz um resumo do que parece ser consenso sobre o uso padrão do INFflex em português, sem deixar de mencionar alguns pontos de conflito (seção 1.1). Apresenta, separadamente, a visão de Maurer Jr., que, apesar de também propor regras para guiar o emprego de INFflex, 
revela uma postura mais aberta à natureza dinâmica das línguas vivas, postura esta em que a presente tese se inspira (seção 1.3).

\subsection{Consensos}

Conforme explicam Cunha \& Cintra (2013 : 498), além do infinitivo impessoal, que "não se refere a uma pessoa gramatical", existe em português o infinitivo pessoal, "que tem sujeito próprio" e pode ser flexionado de acordo com a pessoa do sujeito - recebendo desinências especiais para a $2^{\text {a }}$ pessoal do singular $(-e s)$ e para as três pessoas do plural (-mos, -des, -em) - ou permanecer não flexionado, confundindo-se com o impessoal. Tal semelhança formal entre o infinitivo impessoal e o infinitivo pessoal não flexionado resulta por vezes na apresentação do primeiro como um dos exemplos do segundo, como o fazem Cunha \& Cintra (2013), Lima (2017 [1957]) e Almeida (2009 [1943]). Os seguintes exemplos - acompanhados de sua classificação - são apresentados por Lima (2017 [1957] : 502):

(3) Fumar é nocivo à saúde. (infinitivo impessoal)

(4) Trabalha, meu filho, para agradar a Deus. (infinitivo pessoal não flexionado)

(5) Trabalha, meu filho, para agradares a Deus. (infinitivo pessoal flexionado)

Lima (2017 [1957]:503), então, ao discutir os casos nos quais o infinitivo permanece "não flexionado", apresenta um exemplo semelhante a (3):

(6) Viver é lutar.

O fato de infinitivos impessoais serem citados como exemplos de "infinitivo não flexionado", o que será visto novamente na seção (1.1.2), sugere que, para certos gramáticos, é difusa a distinção entre infinitivo impessoal, infinitivo pessoal flexionado e infinitivo pessoal não flexionado. Para Said Ali, por exemplo, as duas formas de infinitivo usadas em português são "o infinitivo impessoal ou sem flexão, e o infinitivo pessoal ou flexionado" (Said Ali, [s/d.] : 239 - grifo do autor). Nesse sentido, vale lembrar que, nesta tese, os termos INFflex e INFØ se referem às variantes de infinitivos pessoais, que 
podem ou não vir a ser flexionados, ou seja, não se emprega INF $\varnothing$ para fazer referência ao infinitivo impessoal.

A seguir, apresentam-se os consensos entre os gramáticos no que diz respeito ao emprego de INFflex: quando ele "deve" ser usado, (1.1.1), quando não "deve" (1.1.2) e quando seu emprego é "opcional" (1.1.3).

\subsubsection{Quando "se deve" usar INFflex}

Segundo Said Ali (1966, [s/d.]) Bechara (2009), Cunha \& Cintra (2013) e Lima (2017 [1957]), o infinitivo assume a forma flexionada:

i quando tem sujeito expresso, como em Mas o curioso é tu nãa perceberes que não houve nunca "ilusão" alguma; ${ }^{1}$

ii quando tem sujeito próprio, distinto do sujeito da oração principal, que se revela pela desinência verbal, como em Bom seria andarmos nus como as feras;

iii quando, na $3^{\text {a }}$ pessoa do plural, indica indeterminação do sujeito, como em $O$ culpado de tudo é aquele tal de Doutor Reinaldo. Por que não deixou levarem a sujeita para o Recife? ${ }^{2}$

\subsubsection{Quando "não se deve" usar INFflex}

De acordo com Almeida (2009 [1943]), Bechara (2009), Cunha \& Cintra (2013), Said Ali (1966) e Lima (2017 [1957]), o infinitivo conserva a forma não flexionada:

i quando é impessoal, ou seja, quando não se refere a nenhum sujeito e tem sentido vago e abstrato, como em Jurar falso é grande crime $;^{3}$

ii quando tem valor de imperativo, como em E Deus responde - "Marchar!";

1 Os exemplos dos itens i, ii e iii da seção 1.1 .1 são apresentados por Cunha \& Cintra (2013:502-503 grifo próprio).

2 Esse caso é mencionado apenas por Cunha \& Cintra (2013).

3 Os exemplos dos itens i, ii, iv e v da seção 1.1 .2 são apresentados por Cunha \& Cintra (2013: 499-502 - grifo próprio). 
iii quando, precedido da preposição "a", equivale a um gerúndio, com em Olha, viuvinha, já estamos a ouvir teus passos nos surdos corredores da memória ou tem sentido narrativo ou descritivo, como em Mais dois dias. E as meninas a piorar; ${ }^{4}$

iv quando é regido pela preposição "de" e serve de complemento nominal a adjetivos como fácil, possível, bom como em Há decisões fáceis de manter, lembranças difíceis de afastar, cujo sentido é claramente passivo;

v com verbos causativos (deixar, mandar, fazer e sinônimos) e sensitivos (ex. ver, ouvir, sentir e sinônimos) após um sujeito acusativo (pronome oblíquo), como em Esta viu-os ir pouco a pouco. A respeito dessas construções notam-se alguns dissensos: para Lima (2017 [1957]) e Cunha \& Cintra (2013), costuma ocorrer a flexão quando o sujeito é um substantivo ou equivalente, como em Vi teus vestidos brilharem, embora Cunha \& Cintra admitam que se encontram casos de INFflex quando o sujeito é um pronome oblíquo, como em Ele viu-as entrarem, prostrarem-se de braços estendidos, chorando, e não se comoveu.; para Bechara (2009), embora a norma seja o infinitivo aparecer sem flexão com os causativos, o critério não é tão rígido com os sensitivos; por fim, para Almeida (2009 [1943]), nessas construções o infinitivo deve sempre permanecer na forma não flexionada, não importando se o sujeito é um pronome oblíquo ou se é lexical;

vi quando pertence a uma locução verbal e não está distanciado de seu auxiliar, como em E o seu gesto era tão gracioso, coitadinho, que todos, à exceção de Santa, puseram-se a rir. ${ }^{5}$ Said Ali (1966), Almeida (2009 [1943]), Bechara (2009), Cunha \& Cintra (2013) e Lima (2017 [1957]) concordam que, quando o infinitivo se encontra afastado de seu auxiliar, a clareza permite a forma flexionada, como em ... dentro dos mesmos limites atuais podem as cristandades nascerem ou anularem-se, crescerem ou di-

4 Exemplos baseados nos seguintes exemplos oferecidos por Cunha \& Cintra (2013:500 - grifo próprio): Olha, viuvinha, já estou a ouvir teus passos nos surdos corredores da memória e Mais dois dias. E Catarina a piorar.

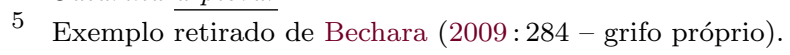


minuírem... ${ }^{6}$ De acordo com o Filtro de Dupla Desinência (FDD) proposto por Perini (1977, 2005 [1995]), são malformadas estruturas que contêm um INFflex precedido por uma forma identicamente flexionada, como em Nós queremos sairmos (Perini, 2005 [1995] : 201). A ocorrência da forma flexionada em complementos de predicados modais e aspectuais, como em Os alunos podem fazerem greve, ${ }^{7}$ é "impossível" de acordo com Modesto $(2011: 72)$. $^{8}$

\subsubsection{Quando o uso de INFflex é "opcional"}

O infinitivo pode ser flexionado:

i quando não pertence a uma locução verbal e há "o intuito ou necessidade de pormos em evidência o agente do verbo" (Said Ali, [s/d.] :246), como em Foram dous amigos à casa de outro, a fim de passarem as horas da sesta. ${ }^{9}$ Concordam e citam esse mesmo trecho de Said Ali os gramáticos Lima (2017 [1957]), Cunha \& Cintra (2013) e Bechara (2009);

ii quando forma uma locução verbal e está distanciado do verbo auxiliar (Bechara, 2009; Cunha \& Cintra, 2013; Lima, 2017 [1957]; Said Ali, 1966), com em Queres ser mau filho, mau amigo, deixares um nódoa d'infâmia na tua linhagem. ${ }^{10}$ No entanto, nenhum desses gramáticos explicita quão distantes precisam estar o infinitivo e o auxiliar para o uso da forma flexionada ser "abonado" (Lima, 2017 [1957] : 506).

\footnotetext{
6 Sobre a combinação do verbo parecer com um infinitivo, embora Said Ali (1966) e Almeida (2009 [1943]) digam que se prefere INF $\varnothing$ quando o verbo parecer é empregado como pessoal (Eles parecem estar doentes) e INFflex quando parecer é usado impessoalmente (Eles parece estarem doentes (Almeida, 2009 [1943]:551 - grifo próprio), Said Ali menciona que são atestadas ocorrências de INFflex com parecer empregado como verbo pessoal na linguagem quinhentista, como em Vinham em tres batalhas armados a seu modo... assi ordenados em fieiras, e modo de cantar, que pareciam virem na ordem... (Said Ali, 1966 : 346 - grifo próprio).

7 Exemplo coletado pela autora em uma assembléia de alunos da USP, em 2013.

8 Perini (1977), Perini (2005 [1995]) e Modesto (2011) não são trabalhos de natureza normativa: o primeiro é uma análise gerativa do INFflex em português, o segundo uma gramática descritiva do português brasileiro e o terceiro é desenvolvido no âmbito do programa minimalista (Hornstein, 2003 apud Modesto 2011).

9 Exemplo retirado de Lima (2017 [1957] : 507 - grifo próprio).

10 Exemplo retirado de Lima (2017 [1957] : 506 - grifo próprio).
} 
iii quando o infinitivo ocorre com verbos causativos e perceptivos e seu sujeito é um substantivo, como em: Finalmente, viu os três pastores pegarem nos alforges e dirigirem-se ao regato, para lavar as mãos ${ }^{11}$ (Cunha \& Cintra, 2013; Lima, 2017 [1957]).

iv em orações adverbiais reduzidas introduzidas por preposição, como em Executaram a palavra de Christo antes de a ouvirem... (Said Ali, 1966:351 - grifo próprio). Para Nougué (2015), porém, não existe opcionalidade quando a oração reduzida se encontra anteposta à oração subordinante, como em Para o entendermos bem, leiamo-lo de novo. Nesse caso, o gramático entende que "é de regra flexionar" o infinitivo, caso contrário "só se conhece o sujeito da subordinada após ler a subordinante" (Nougué, $2015: 575)$.

v quando serve de complementos a substantivos e adjetivos, como em: Os godos, porém, tinham a vantagem de caminharem ordenados ou em Requeimados pelo sol argente... incapazes de conhecerem a vantagem da ordem e disciplina... (Said Ali, 1966:349 - grifo próprio). Modesto (2011:72) se refere a esses casos como "complementos oracionais de nomes";

vi em estruturas nas quais o objeto da oração principal controla a referência do sujeito do infinitivo, como em O Paulo convenceu os meninos a viajarem de carro (Modesto, $2011: 69) .{ }^{12}$

\subsection{Dissensos}

Embora os gramáticos Said Ali ([s/d.] : 246), Bechara (2009), Cunha \& Cintra (2013), Cipro Neto \& Infante (2010) e Lima (2017 [1957]) concordem que, em casos como As crianças são acalentadas por dormirem, ${ }^{13}$ a escolha entre flexionar ou não o infinitivo depende dos objetivos do usuário da língua -

11 Exemplo retirado de Cunha \& Cintra (2013:502 - grifo próprio).

12 Segundo Modesto (2011:69), entre os verbos de controle de objeto cujos complementos são opcionalmente flexionados estão "predicados diretivos, de influência e autorização exigir, instruir, aconselhar, recomendar, permitir, autorizar, sugerir, entre outros".

13 Exemplo retirado de Bechara (2009:351 - grifo próprio). 
destacar a ação ou, intencionalmente, dar destaque à pessoa verbal a que o infinitivo se refere (seção 1.1.3 item i) -, Almeida (2009 [1943], 1981) discorda do posicionamento desses gramáticos. Na verdade, ele não apenas discorda de seus colegas, mas considera "desprezível o argumento de que o flexionamento serve de insistir na pessoa do sujeito" (Almeida, 1981:150), criticando aqueles que chegam à conclusão de que a questão do emprego de INFflex pertence mais ao campo da estílistica do que ao da gramática. Para ele, o emprego de INFflex "deve limitar-se aos casos de real necessidade de evidenciar, de identificar, de indicar o sujeito, e não subordinar-se a caprichos de estilo". De fato, ele chama de "extravagante e tola" a flexão do infinitivo quando os sujeitos são idênticos e a necessidade de clareza não a exige (Almeida, $1981: 155)$.

Apesar de mencionar o emprego opcional da flexão em alguns casos como, por exemplo, quando o infinitivo está distante do verbo auxiliar -, o gramático acredita que, mesmo nesses casos, a flexão é "supérflua e inconveniente" (Almeida, 2009 [1943]:155), chegando a citar a seguinte "atrocidade" produzida por um jornalista: Como poderão o congresso e o presidente trabalharem juntos? (Almeida, 1981: 155).

Entre inúmeros exemplos jornalísticos que são alvo de críticas, encontramse ocorrências de INFflex em complementos de substantivos (...dando à minorias o direito de se organizarem e de manifestar seu ponto de vista), de adjetivos (Acusados de prepararem boletins considerados subversivos) ou ainda em construções com verbos perceptivos (... quando viram os brasileiros chegarem), usos que Said Ali (1966), por exemplo, considera opcionais. Nesses casos, segundo Almeida, "não cabe justificativa nem de clareza nem de harmonia, nem de precisão, muito menos de economia de expressão" (Almeida, 1981 : 151).

Por fim, entre as afirmações emblemáticas e polêmicas por parte desse gramático, destacam-se:

"O abuso cada vez maior da pessoalização do infinitivo é uma das várias provas da contínua deteriorização do nosso idioma e da insegurança de sua sintaxe para a expressão do pensamento." (p. 156)

"O abuso da flexão chega a parecer-nos que o redator julga cometer 
erro de concordância se não pluralizar o infinitivo; o erro está em não saber ele o que é infinitivo e em não conhecer as poucas regrinhas a que se subordina a flexão." (p. 153)

"Por que dizer 'A tendência dos modernos e estudiosos da língua é reconhecer que não há regras fixas e definitivas a respeito do assunto'? Ora! Sejamos mais sinceros e digamos: A conjugação do infinitivo é a maior prova de putrefação do nosso idioma ou, para maior suavidade, é consequência de confusão com o futuro do subjuntivo ou, ainda mais delicadamente, é resultante necessária da falta de escolas. Se em nenhum outro idioma provindo do latim o infinitivo é conjugado, como dizer que precisamos conjugar o infinitivo nosso?" (p. 150)

O posicionamento de Almeida (2009 [1943], 1981) em relação ao emprego INFflex é um exemplo típico do que Cameron (1995) chama de higiene verbal, que são “... discursos e práticas através dos quais as pessoas tentam 'limpar' a língua, procurando conformar a estrutura ou uso da língua aos seus ideais de beleza, verdade, eficiência, lógica, correção e civilidade..." (Cameron, 1995 : vii). ${ }^{14}$ Práticas normativas relacionadas à língua "podem expressar também ansiedades mais profundas que não são linguísticas, mas sociais, morais e políticas" (Cameron, 1995), ${ }^{15}$ o que parece ser o caso desse gramático. $^{16}$

Ao contrário de Almeida (2009 [1943]), que vê a expansão do emprego de INFflex em PB como um exemplo de decadência linguística, nesta tese, aborda-se essa questão como um fenômeno natural da língua, assim como Maurer Jr. (1968), cuja perspectiva é apresentada a seguir.

14 Original: “... discourses and practices through which people try to 'clean up' language and make its structure or its use conform more closely to their ideals of beauty, truth, efficiency, logic, correctness and civility..."

15 Original: “...may also express deeper anxieties which are not linguistic, but social, moral and political."

16 Embora práticas como essas se oponham ao que se faz na Linguística - ciência descritiva e não prescritiva -, Cameron chama a atenção de linguistas para a necessidade de procurar entender a lógica por trás das crenças que as pessoas têm a respeito da língua, em vez de simplesmente desprezá-las e considerá-las não científicas. Segundo a autora, compreendendo melhor a motivação de tais práticas de higiene verbal e despidos de preconceito, linguistas podem enriquecer o debate público sobre a língua. 


\subsection{A visão de Maurer Jr.}

Maurer Jr. (1968) faz uma distinção entre três casos de infinitivo: aqueles que são indiscutivelmente impessoais, aqueles que são claramente pessoais e aqueles nos quais INFflex é facultativo. Para os dois primeiros casos, o filólogo apresenta "regras que, no uso normal e corrente da língua, não admitem exceção" (Maurer Jr., 1968: 135). Tais regras, que estão em consonância com o que foi exposto nas seções 1.1.1 e 1.1.2, são as seguintes:

REGRA I

Quando o infinito é rigorosamente impessoal, isto é, quando a ação por ele expressa não se refere a nenhum agente determinado, quer enunciado com o próprio infinito, quer indicado no contexto, ele é sempre invariável (impessoal). (Maurer Jr., 1968:235) ${ }^{17}$

REGRA II

Quando o infinito é claramente pessoal, isto é, quando tem sujeito próprio - expresso ou não -, é sempre flexionado, pouco importando que o seu sujeito seja idêntico ao do verbo regente ou não. (Maurer Jr., $1968: 236)$

A respeito do terceiro caso, no qual se emprega INFflex facultativamente, afirma o filólogo:

"Acontece, porém, que a impessoalidade do infinito nem sempre é absoluta. Embora ele não seja provido de um sujeito próprio, entretanto a ação ou o processo que ele exprime pode ser conhecido, pois que vem expresso, de algum modo, no contexto, em relação com a palavra verbo, substantivo, adjetivo, etc., - de que o infinito depende. Quando tal acontece, é fácil de compreender que, existindo na língua uma forma própria para exprimir a pessoalidade, esta possa empregar-se em lugar da forma impessoal comum (...) Foi isto exatamente o que aconteceu em nossa língua: desde os mais antigos documentos escritos o infinito

$\overline{17}$ Maurer Jr. (1968) usa o termo "infinito" para se referir ao que, nesta tese, se chama de infinitivo. 
flexionado se empregou não só para indicar que ele tem sujeito próprio, mas usou-se também - em uma escala ascendente - nos casos em que o agente da ação por ele expressa era conhecido pelo contexto." (Maurer Jr., 1968:234)

"Surge assim ao lado do emprego obrigatório do infinito invariável ou do flexionado, uma larga faixa de empregos mais ou menos facultativos da forma invariável ou da flexionada, conforme a construção em que ocorra ou as exigências da clareza e da expressão." (Maurer Jr., 1968 :235)

É preciso atentar para o fato de que Maurer Jr. (1968) emprega o termo "invariável" ora no sentido de "que não varia", como o faz ao apresentar a regra I, ora no sentido de "sem flexão", como faz ao situar a forma invariável na "faixa de empregos mais ou menos facultativos". Em se tratando de empregos facultativos, já não se pode interpretar o termo "invariável" no sentido de que "não apresenta variação"; pelo contrário, se é facultativo, pode haver variação. Sendo assim, no caso da faixa de "empregos mais ou menos facultativos", na qual Maurer Jr. entende que se situam as hesitações e dúvidas (Maurer Jr., 1968:235), deve-se interpretar a "forma invariável" como a variante INF $\varnothing$, já que tanto ela quanto a variante INFflex podem ocorrer. Em termos variacionistas, é nessa faixa que Maurer Jr. situa o envelope de variação.

Embora utilize o termo "infinito invariável" em seu quadro sinóptico dos usos facultativos, ${ }^{18}$ pode-se dizer que, nesse quadro, transcrito literalmente a seguir, Maurer Jr. resume sua visão acerca da variação entre INFØ e INFflex. INFINITIVO INVARIÁVEL OU O INFINITO FLEXIONADO

A Quando o infinito se prende a um verbo regente e a ação por ele expressa se refere ao sujeito do mesmo verbo.

18 Na transcrição, reduziu-se a quantidade de exemplos, sublinharam-se os infinitivos e colocou-se a flexão em parênteses nos casos em que, de fato, havia exemplos com as duas variantes. Os exemplos que não contêm os parênteses com as flexões opcionais são, portanto, exemplos que foram apresentados com apenas umas das variantes. Optou-se por manter tais inconsistências não apenas para ser fiel ao original, mas, também, por acreditar-se que tais consistências podem ser indícios de que, entre os usos apresentados como facultativos, Maurer Jr. considera alguns mais ou menos facultativos. 
a Com um verbo auxiliar e com verbos de movimento, com valor de infinito final.

Queremos voltar logo.

Vieram buscar as crianças.

Correram a pegar a bola.

Costumavam os filhos ... reunirem-se.

Vamos, pois, ao túmulo, considerarmos-lhes o vazio, e escutarmos o anúncio do anjo

b Com um verbo transitivo direto ou indireto, servindo o infinito de complemento ao referido verbo.

Todos se queixam de não ter(em) tempo para a reunião.

Todos afirmaram solenemente nada ter(em) visto do que aconteceu.

Jactam-se de ser(em) os primeiros.

c Quando o infinito constitui uma oração adverbial reduzida.

Viemos cedo, por estar(mos) ansiosos de conhecer os resultados.

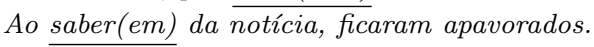

B Quando o infinito se prende a um verbo regente e a ação por ele expressa se refere ao objeto direto ou indireto do mesmo verbo.

a O infinito funciona como um predicativo do objeto direto - raramente do indireto - ou do sujeito, quando o verbo regente está na passiva.

1 emprega-se de preferência o infinito invariável quando o complemento do verbo regente é um pronome pessoal ou quando, sendo outro pronome qualquer ou substantivo, está posposto ao infinito.

Mandaram-nos sair.

Ouvir chegar os carros.

Deixou entrar alguns.

2 Emprega-se mais comumente o infinito flexionado quando o complemento do verbo regente, sendo um substantivo ou um pronome qualquer, menos o pessoal, vem anteposto ao infinito.

Mandaram os meninos saírem.

Deixou muitos fugirem.

Quando o verbo regente está na passiva - geralmente formada com a partícula se - admitem-se duas construções diferentes.

1 emprega-se a forma pessoal do verbo regente, ficando o infinito na forma invariável.

Viam-se passar ao longe numerosos cavaleiros.

Ouviam-se ressoar docemente uns ternos harpejos de gusla.

2 constrói-se impessoalmente o verbo regente, indo o infinito para a forma flexionada.

Via-se passarem ao longe numerosos cavaleiros.

Ouvia-se ressoarem docemente uns ternos harpejos de gurla.

b O infinito serve de objeto direto ao verbo regente (de sujeito, quando o verbo regente é passivo ou unipessoal, do tipo "Convém fazer" e semelhantes) e a ação por ele expressa se refere ao objeto indireto ou complemento de atribuição do mesmo verbo.

Permitiram-nos participar(mos) dos jogos.

Consenti-lhes sair(em) mais cedo.

c O infinito, sempre preposicionado, serve de complemento terminativo do verbo regente e a ação por ele expressa se refere ao objeto direto ou ao objeto indireto do mesmo verbo (ao sujeito, quando o verbo está na passiva).

Convidaram-nos a participar(mos) dos jogos.

Aconselhei os candidatos a desistir (em) da prova.

Nada nos impede de lutar( $\overline{\text { mos) }}$ pela vitória dessa causa justa.

Foram obrigados a sair(em) imediatamente.

C Quando o infinito regido das preposições a ou sem se prende a um substantivo ou a um pronome, formando expressões equivalente a um gerúndio. 
a Ligado ao objeto direto de verbos como ver, ouvir, sentir, encontrar, haver, etc. e do advérbio eis. Vi as crianças a correr(em) pelas ruas.

Encontrou-nos a ler(mos) uma velha lenda oriental.

b Formando, com um substantivo ou pronome a que se prende, ou mesmo sozinho, um complemento circunstancial de modo, de concomitância, ou ainda um simples atributivo, como equivalente de uma oração relativa.

Acordaram tarde, com os raios de sol a entrar(em) pela janela.

Passaram a tarde toda a discutir(em) o assunto.

c Como infinito narrativo ou descritivo.

Amanheceu e anoiteceu o seguinte dia e eles a bailar(em).

Os interessados divertindo-se e folgando indiferentes a tudo, e nós a nos fatigar(mos) inutilmente por eles.

D Quando o infinito preposicionado serve de complemento a um substantivo ou a um adjetivo, cujo agente é conhecido do contexto ou indicado pelo próprio substantivo ou adjetivo.

a Um infinito dependente de um substantivo, cujo agente é conhecido do contexto.

Deram-lhes a esperança de ser(em) nomeados.

Eles têm a vantagem de conhecer(em) bem o grego e o latim.

b Um infinito dependente de um adjetivo, que se refere a um agente conhecido do contexto.

Estamos ansiosos por conhecer(mos) os resultados da votação.

Estavam todos desejosos de ouvir(em) a mensagem presidencial.

Estes, certos de ter(em) assegurado a vitória, tornaram-se negligentes e descuidados.

c Um infinito dependente de um substantivo que constitui o agente ou de um adjetivo que a ele se refere.

Punha jóias de causar(em) inveja às suas vaidosas colegas.

Submetia-se a provações de abalar(em) nervos de aço.

E Quando o infinito vem em uma oração subordinada de valor interrogativo-deliberativo ou em orações relativas do tipo "não tenho o que fazer" e semelhantes, e a ação por ele enunciada se refere ao sujeito ou a um complemento da oração regente.

Não sabemos onde buscar(mos) pão para tanta gente.

Nunca nos proporcionaram os meios com que realizar(mos) o curso superior.

F Finalmente, mesmo quando o infinito não esteja na dependência direta de qualquer palavra regente verbo, substantivo, adjetivo, etc. - o seu emprego é facultativamente pessoal ou impessoal, desde que o agente a que se refere a ação por ele expressa venha indicado de qualquer forma no contexto.

É dever de todos nós respeitar(mos) os direitos dos outros.

Já estais informados de tudo: agora é tempo de agir(des).

Perdestes tantas oportunidades excelentes! Como recuperar(des) agora o tempo perdido?

A comparação desse quadro com os usos opcionais apresentados na seção 1.1.3 deixa claro que a proposta de Maurer Jr. (1968) abarca um número maior de contextos sintáticos. Pode-se destacar, por exemplo, a opcionalidade de INFflex nas chamadas infinitivas gerundivas, que, de acordo com os gramáticos apresentados na seção 1.1.2, são contextos nos quais "não se deve" empregar INFflex. 
Em todos esses casos apresentados como facultativos, Maurer Jr. (1968: 154) afirma não haver dúvida de que "originariamente" a construção não flexionada seria a "normal". Defensor da hipótese da criação do INFflex a partir do "infinito românico comum" (Maurer Jr., 1968: 100), ${ }^{19}$ Maurer Jr. afirma que, uma vez criada a forma flexionada, nota-se "uma tendência para alargar sempre mais o seu emprego, mesmo em construções nas quais seria difícil descobrir um sujeito do infinito: basta que a ação por ele expressa seja sentida como realizada por um agente determinado, para que a forma flexionada surja, ainda quando a forma verbal da oração regente já tenha designado esse agente" (Maurer Jr., 1968: 89, grifo próprio).

Convém destacar que "sentir" a necessidade de flexão é, obviamente, algo mais subjetivo do que a "intenção" de colocar em evidência a pessoa verbal do infinitivo. Fica evidente, portanto, uma visão bastante aberta em relação à possibilidade de expansão de INFflex, condizente com a dinâmica das línguas vivas, em constante processo de variação e mudança.

Inspirada na visão de Maurer Jr. (1968), além de realizar uma análise quantitativa do emprego variável de INFflex em três dos contextos facultativos apresentados no quadro - orações adverbiais, complementos de substantivos e complementos -, esta tese investiga, por meio de um experimento de percepção sociolinguística, possíveis significados sociais associados a INFflex, que, juntamente com aumentos na frequência de uso em certos contextos, podem estar relacionados à expansão do emprego de INFflex para novos contextos prevista por Maurer Jr..

\subsection{Estudos empíricos sobre INFflex}

\subsubsection{INFflex em português brasileiro: textos jornalísticos}

Em uma pesquisa variacionista, Ladeira (1986 apud Cabral 2006) analisou dados de infinitivo extraídos de editoriais do Jornal do Brasil e da Bíblia de

\footnotetext{
19 Há diferentes teorias a respeito da origem formal do INFflex no português: além da teoria adotada por Maurer Jr., de acordo com a qual o infinitivo flexionado teria se originado a partir do infinitivo românico comum por influência da semelhança formal com o subjuntivo futuro, outros autores, tais como Scida (2004), defendem que INFflex deriva do subjuntivo imperfeito latino. Para uma discussão detalhada sobre as diferentes teorias sobre a origem de INFflex, ver Scida (2004).
} 
Jerusalém e, entre os fatores favorecedores de INFflex, encontrou: a primeira pessoa do plural (1PP); a posição anteposta da oração infinitiva em relação à oração principal; a distância entre o verbo da oração principal e o infinitivo; a presença de predicativo ou particípio plurais; o fato de ocorrer em orações adverbiais e causais, bem como a presença de pronomes reflexivos. Além disso, constatou-se que a ocorrência de pronome oblíquo na posição de sujeito do infinitivo se revelou um fator inibidor da flexão.

Com base nesses achados, Cabral (2006) analisou dados extraídos de textos de opinião e de notícias do Jornal do Brasil e do jornal O Globo com o objetivo de verificar se a variação é de fato guiada por questões estilísticas, como defendem muitos gramáticos, ou se há fatores sintáticos, semânticos e extralinguísticos que se correlacionam ao emprego de INFflex. As hipóteses que orientaram seu trabalho foram as de que (i) a variação não é aleatória, mas condicionada por fatores gramaticais; (ii) em decorrência do uso frequente da concordância verbal (Naro \& Scherre, 2003) e da preferência pelo sujeito pronominal expresso no português do Brasil (Duarte, 1995), na língua padrão emprega-se mais frequentemente INFflex do que INFØ; e (iii) a maior distância entre o infinitivo e o SN que comanda sua referência favorece o uso das marcas flexionais.

Do total de 1009 ocorrências extraídas, 41 foram de orações infinitivas completivas de verbos causativos e perceptivos e 968 de orações infinitivas controladas por um SN plural na oração principal, sendo que esses dois conjuntos de dados foram analisados separadamente. ${ }^{20}$ No caso da orações de verbos causativos e perceptivos, foram testados o tipo de verbo (causativos $\mathrm{x}$ perceptivos), estrutura do sujeito da oração infinitiva (pronome acusativo, nominativo ou SN) e a ordem (sujeito+infinitivo ou infinitivo+sujeito). Já entre os fatores testados na análise das demais orações estão o tipo de oração (completivas verbais, completivas de adjetivo, completivas de substantivo, relativas não canônicas e adverbiais), a forma do controlador da concordância (SN, pronome expresso, pronome nulo, clítico acusativo e clítico dativo), voz verbal e presença de preposição. No subgrupo das orações adverbiais, testou-se

\footnotetext{
20 Nada se menciona no estudo a respeito de como foi feita a extração dos dados ou de quantos textos jornalísticos foram usados.
} 
sua posição em relação à oração principal (anteposta x posposta). O único fator testado para o conjunto total de dados foi o fator extralinguístico gênero textual (texto de opinião x notícias).

A análise, que levou em conta valores percentuais (e não pesos relativos), revelou uma maior taxa de INF $\varnothing$, contrariando as expectativas iniciais. Verificou-se, ainda, que as orações relativas não canônicas e a voz passiva são contextos "que mais favorecem" INFflex (Cabral, 2006:84). Em relação às orações com verbos causativos e perceptivos, observou-se que o sujeito representado por um SN e anteposto ao infinitivo "foram fatores decisivos para que houvesse" INFflex (Cabral, 2006 : 84). Não se sabe, no entanto, se as diferenças encontradas são, de fato, estatisticamente significativas, uma vez que não houve tratamento estatístico dos dados.

\subsubsection{INFflex em português brasileiro: textos acadêmicos}

Canever (2012) analisou a variação no emprego de INFflex em um corpus formado por 180 teses e dissertações produzidas por alunos de pós-graduação da área de Letras da FFLCH-USP em um estudo exploratório (Gries, 2013) motivado por usos não padrão do infinitivo, tais como:

(7) Os fenômenos sob análise acabam por não serem registrados de forma sistemática, prejudicando a sustentação empírica dos trabalhos (LLIC_ev29mar09) ${ }^{21}$

(8) Eu e meu primo viemos para São Paulo para podermos lançarmos nosso cd. (LLIC_fc31mai09)

(9) Nós não vamos nos determos nessa questão. (LLIC_fc15jun10)

(10) Nós temos que nos prepararmos para a Copa de 2014. (LLIC_ev06jul10)

(11) As autoridades têm que repensarem isso. (LLIC_fc10jan11)

(12) Favor desligarem seus celulares! (LLIC_fc26set10)

Nos exemplos 7-11, os infinitivos fazem parte de locuções verbais, servindo de complemento de verbos auxiliares, um contexto no qual o emprego da

\footnotetext{
21 Os dados identificados por LLIC foram coletados por membros do Laboratório “Linguagem, Interação, Cognição" da USP em diferentes contextos, entre eles aulas e reuniões universitárias, e-mails institucionais e textos jornalísticos.
} 
flexão é considerado "impossível” (Modesto, 2011) e agramatical (Perini, 1977). Também não é considerado padrão o emprego da flexão quando infinitivo tem valor de imperativo (seção 1.1.2), como no exemplo 12. Embora destoem do que é considerado padrão ou mesmo gramatical (de acordo com julgamentos formalistas), tais ocorrências estão em perfeito acordo com as hipóteses aventadadas por Maurer Jr. (1968). Produzidos por falantes escolarizados, esses dados de língua em uso evidenciam (i) que tais usos não são impossíveis e (ii) que, como Maurer Jr. (1968) já previa, INFflex está se espalhando para novos contextos sintáticos.

A partir dessa constatação, investigou-se, na escrita padrão, as tendências de uso nos contextos sintáticos que Maurer Jr. considera facultativos. Dada a expansão de INFflex para contextos não padrão, haveria preferência pelas formas flexionadas em casos de opcionalidade?

Os resultados revelaram uma maior tendência de emprego de INFflex em orações temporais, orações causais, orações finais, complementos adjetivais, complementos nominais, enquanto em orações completivas o INF $\varnothing$ foi mais frequente. ${ }^{22}$ Entre as assimetrias identificadas, estão (i) uma preferência acentuada por INFflex em orações finais com 1PP e (ii) maiores taxas de INFflex na voz passiva, tanto em orações finais com 3PP quanto em complementos de adjetivos e substantivos.

Por se tratar de um corpus de língua escrita padrão, não se esperavam ocorrências de usos não padrão de INFflex; houve, porém, casos de INFflex em locuções verbais:

(14) As virtudes começam a serem tratadas no capítulo 8. (fran_12) ... as relações entre literaturas passaram a serem estudadas ... (fran_15)

(16) Depois as pessoas pobres acabam por tornarem-se .... (fran_2)

A despeito da baixa frequência de ocorrências desse tipo, o fato de usos não

22 Tais resultados são retomados na seção 1.5 e no capítulo 3.

23 A identificação dos exemplos encontrados por Canever traz as iniciais da área das teses das quais os exemplos foram retirados e o número da tese no Corpus PósLetrasUsp; nesse caso, o exemplo identificado por dlo_29 foi encontrado na tese 29 do Departamento de Línguas Orientais (DLO), da FFLCH; os exemplos seguintes, identificados por fran, foram encontrados em teses da área de Francês. 
padrão como esses serem atestados em um contexto de escrita acadêmica com tamanho grau de formalidade e automonitoramento é indício de que o emprego variável da concordância do infinitivo em locuções verbais é uma realidade na língua culta atual.

\subsubsection{INFlex em português europeu: orações adverbiais}

Diante da aparente redundância pragmática que se configura com o emprego de INFflex em casos opcionais, Vanderschueren \& Diependaele (2013) testaram a hipótese de que infinitivos tendem a ser mais frequentementes flexionados quando seus sujeitos são menos acessíveis cognitivamente (Vesterinen, 2006). Baseada na teoria de acessibilidade de Ariel (1991, 1996, 2001 apud Vesterinen 2006, a escala de proeminência dos infinitivos portugueses proposta por Vesterinen (2006) traz, no extremo de maior proeminência, infinitivos flexionados com sujeitos lexicais, seguidos por infinitivos não flexionados com sujeito lexicais, ao passo que no extremo de menor proeminência se encontram infinitivos flexionados sem sujeito explícito, seguidos por infinitivos não flexionados sem sujeito explícito. Partindo da premissa de que a escolha por uma forma mais ou menos proeminente está diretamente ligada ao grau de acessibilidade mental do referente, Versterinnen postula que o uso de infinitivos mais proeminentes refletem um menor grau de acessibilidade do sujeito do infinitivo. Assim, em havendo dificuldade na recuperação ou identificação do sujeito, a forma INFflex tenderia a ser preferida, enquanto INFØ seria empregada nos casos de infinitivo com sujeito altamente acessível.

Para testar empiricamente essa hipótese, o estudo se concentrou em contextos adverbiais, mais especificamente infinitivos sem sujeito explícito, que ocupam os níveis mais baixos da escala de proeminência apresentada por Vesterinen (2006). Utilizaram-se dados do estudo de corpus realizado por Vanderschueren (2013), ${ }^{24}$ além de dados experimentais obtidos através de um teste psicolinguístico de leitura automonitorada. ${ }^{25}$

\footnotetext{
24 O corpus é formado por obras literárias de autores portugueses e textos do jornal O Público.

25 Self-paced reading (SPR). A tarefa, realizada por 61 alunos portugueses da Universidade de Lisboa, consistiu na leitura (na tela do computador) de 160 sentenças - 80 sentenças com infinitivo e 80 sentenças distratoras -, sendo que as palavras de cada sentença se tornavam visíveis uma a uma, à medida que os participantes pressionavam a barra de espaço. O tempo de reação da leitura de cada
} 
No estudo de corpus, testaram-se três fatores relacionados à maior ou menor acessibilidade do sujeito do infinitivo: presença de pausa entre o infinitivo e a oração principal, posição da oração infinitiva em relação à oração principal e distância entre o infinitivo e a oração que contém o referente de seu sujeito. As análises demonstraram efeitos das três variáveis: INFflex foi empregada mais frequentemente (i) na presença de pausa, (ii) em orações antepostas e (iii) quanto maior a distância entre o infinitivo e o referente do seu sujeito.

No experimento de leitura automonitorada, os mesmos fatores - pausa, posição e distância - foram testados em relação ao tempo de reação da leitura $(\mathrm{RT})^{26}$ dos próprios infinitivos e das demais palavras da sentença, além de terem sido considerados fatores como frequência lexical, tamanho da palavra, RT anterior, número da sentença, distância em relação à primeira palavra da sentença, distância em relação à última palavra da sentença. A partir das análises, observou-se uma vantagem cognitiva do emprego de INFflex (i) quando ainda havia muita informação para ser processada e (ii) com verbos infrequentes - com verbos frequentes, por outro lado, INFflex tornou o processamento mais lento. Assim, os autores concluem, então, que o emprego de INFflex facilita o processamento de sentenças complexas.

Em um outro estudo que tomou como base os dados provenientes do estudo de corpus de Vanderschueren (2013), Vanderschueren \& de Cuypere (2014) realizaram uma análise multifatorial de variáveis que potencialmente influenciam a escolha por INFflex ou por INFØ em orações adverbiais introduzidas por antes de, ao, depois de, por, para e sem. Avaliou-se o efeito de 14 variáveis linguísticas relacionadas a três princípios gerais que, segundo enfoques cognitivo-funcionais, estão relacionados ao emprego de INFflex: autonomia da oração infinitiva, acessibilidade cognitiva do sujeito e verbalidade. ${ }^{27}$

palavra foi definido como o tempo entre duas tecladas na barra de espaço. Os participantes foram instruídos a prestar atenção ao conteúdo das sentenças, através de perguntas a seu respeito ao final de algumas delas.

26 Reaction time.

27 Vanderschueren (2013:38-39) situa o infinitivo em uma escala gradual entre verbos finitos e nomes: se aproximam de verbos finitos, por exemplo, infinitivos que ocorrem em perífrases verbais, em orações adverbiais e com negação - características prototipicamente verbais -, enquanto infinitivos acompanhados de artigos se aproximam de sintagmas nominais. Nesse sentido, considera-se que o infinitivo português, que pode receber desinências número-pessoais, apresenta um caráter mais verbal, especialmente quando flexionado. Levando-se em conta o critério semântico, são considerados prototípicos 
A Tabela 1.1 apresenta as 14 variáveis linguísticas que foram testadas, os princípios com que estão relacionadas e os efeitos esperados.

Tabela 1.1 Efeitos esperados das variáveis testadas por Vanderschueren \& de Cuypere (2014)

\begin{tabular}{clll}
\hline & Variável & Princípio & Efeito esperado \\
\hline 1 & Conector (preposição) & Autonomia & menos flexão com para e sem \\
2 & Posição & Autonomia/acessibilidade & mais flexão com anteposição \\
3 & Pausa & & mais flexão com pausa \\
4 & Distância do antecedente & & mais flexão com maior distância \\
5 & Tamanho da oração & & mais flexão com mais palavras \\
6 & Presença de oração & Autonomia & mais flexão quando há outra oração \\
7 & Dependência & Ausência de referência pessoal & menos flexão quando há dependência sintática \\
8 & Verbo principal impessoal & mais flexão com verbo principal impessoal \\
9 & Reflexividade & Verbalidade & mais flexão com verbos reflexivos \\
10 & Perífrase & & mais flexão com perífrases \\
11 & Negação & & mais flexão com negação \\
12 & Inacusatividade & mais flexão com verbos transitivos e inergativos \\
13 & Aspecto lexical & & menos flexão com verbos de estado \\
14 & Frequência de tipo & Economia & mais flexão com verbos infrequentes \\
\hline
\end{tabular}

Testes estatísticos confirmaram que os três princípios propostos são relevantes para a explicação da alternância entre INFflex e INFØ. INFflex foi favorecido em orações infinitivas mais autônomas e, no que diz respeito ao status verbal de infinitivo, ou seja, em relação à sua posição no contínuo entre verbos finitos e nomes, as variáveis Reflexividade, Negação e Perífrase apresentaram efeitos significativos: infinitivos com características mais prototipicamente verbais foram mais frequentemente flexionados. Contrariando a hipótese de que verbos com menor grau de verbalidade - verbos menos protípicos, tais como verbos de estado e verbos inacusativos - seriam menos flexionados, tais verbos foram mais frequentemente flexionados do que não flexionados, o que os autores interpretaram como uma possível compensação de verbalidade: o emprego de INFflex estaria conferindo características verbais a verbos menos prototípicos. Verificou-se, ainda, uma chance de ocorrência de INFflex maior com antes de, depois de e por e menor com para, sem e ao.

Interpretando seus resultados à luz do enfoque cognitivo-funcional, Vanderschueren \& de Cuypere afirmam que o emprego de INFflex é iconicamente motivado, uma vez que é um meio formal usado para expressar uma função semântica: a flexão marca a natureza verbal do infinitivo e aproxima as orações infinitivas de orações principais. Afirmam, ainda, que o emprego de INFflex também serve para facilitar a compreensão, uma vez que explicita

verbos transitivos e inergativos, que tipicamente têm sujeitos agentivos, além de verbos de atividade, accomplishment e achievement (Vendler, 1957). Verbos inacusativos e que denotam estados, por sua vez, são verbos menos prototípicos. 
sujeitos não facilmente recuperáveis do contexto. Por fim, concluem que o fato dessa "marca flexional adicional" ser restrita a certos contextos morfossintáticos demonstra que o emprego de INFflex é econômico, ou seja, só é empregado quando "se sente" que é necessário (Vanderschueren \& de Cuypere, $2014: 171)$.

É interessante destacar o fato de que o que esses autores afirmam em relação ao português europeu - a respeito do emprego econômico de INFflex - se contrapõe ao que se tem notado na variedade brasileira, uma vez que dados atestados na língua em uso do PB contemporâneo revelam usos nada econômicos, tais como:

(17) Sim, e deveríamos, enquanto país, termos estratégias semelhantes em várias frentes. $^{28}$

Assim como Maurer Jr. (1968) previa (seção 1.3), INFflex parece estar se espalhando para novos contextos em PB e, nesse processo de expansão, não parece estar o jogo o princípio da economia.

\subsubsection{INFlex em português europeu: construções causativas e perceptivas}

Outro estudo sobre INFflex em PE foi realizado por Bossaglia (2013b), que analisou, no corpus CETEMPúblico, a variação no emprego de INFflex em construções com verbos causativos (CCs: verbos causativos "genéricos" fazer, deixar e mandar e verbos "inerentemente" causativos permitir, impedir e obrigar) e em construções com verbos perceptivos (PCs: ver, ouvir, sentir, olhar, observar e escutar).

Partindo da premissa teórica de que uma maior integração semântica corresponde a uma maior integração sintática (Givón, 1995), Bossaglia (2013b) investigou se o fato de PCs serem menos integradas semanticamente - e portanto, mais independentes sintaticamente - favoreceria o emprego de INFflex.

Os resultados dessa análise, além de confirmar o maior grau de liberdade

\footnotetext{
28 Dado coletado pela autora em 9 de julho de 2014 e produzido em uma entrevista na tv.
} 
no uso de INFflex em PCs, demonstram que, entre as CCs, os verbos permitir, obrigar e impedir apresentam taxas de INFflex ligeiramente superior em relação aos causativos fazer, deixar e mandar. Bossaglia atribui essa diferença nas taxas de INFflex entre os verbos causativos (i) à natureza mais agentiva dos verbos permitir, obrigar e impedir em comparação aos demais (ii) à presença de preposição após os verbos obrigar e impedir, uma vez que orações infinitivas introduzidas por preposições são menos integradas sintaticamente, o que favorece a ocorrência de INFflex. ${ }^{29}$

O estudo também revelou dados "irregulares" (Bossaglia, 2013b:228), nos quais a autora afirma que o emprego de INFflex não era esperado, como os seguintes: ... não os deixa ficarem sozinhos.

(19) Nunca os ouvi reclamarem o ordenamento do território.

(20) Quero desarmar as pessoas, fazê-las serem elas próprias.

(21) Vi-os assinarem a paz com a maioria dos clãs...

Para Bossaglia, esses exemplos são considerados "irregulares", porque, de acordo com uma perspectiva formalista, em se tratando de estruturas com marcação excepcional de caso (ECM), nas quais o sujeito do infinitivo recebe caso acusativo do verbo principal, apenas INFØ poderia ocorrer.

A autora interpreta essas construções como fruto do que chama de "supergeneralização" do emprego de INFflex Bossaglia (2013b:228-229). Destaca, ainda, que usos "irregulares" como esses foram mais frequentes com os verbos permitir, obrigar e impedir, cuja preferência por sujeitos mais agentivos e natureza preposicional dos complementos (no caso de obrigar e impedir) podem servir de gatilho ou facilitar a "supergeneralização" de INFflex nesses contextos.

\footnotetext{
29 Segundo a autora, INFflex se originou nas orações adverbiais introduzidas por preposição e nos complementos de nomes e de adjetivos em função da menor integração sintática resultante da presença de preposição (Bossaglia, 2013a:27).
} 


\subsection{Síntese}

Neste capítulo, apresentaram-se diferentes perspectivas sobre emprego de INFflex em português: após um resumo dos consensos e dissensos entre diferentes gramáticos acerca do que seria o uso padrão de INFflex, apresentouse a visão de Maurer Jr. (1968: 89), que, já na década de 1960, falava de uma tendência natural de expansão de INFflex para contextos sintáticos nos quais falantes viessem a "sentir" que o infinitivo tinha um agente. Apresentaram-se, ainda, estudos que investigaram o emprego variável de INFflex em PB e em PE a partir de dados de língua escrita padrão. Partindo do panorama aqui exposto, o próximo capítulo inicia-se com as questões que se colocam em relação ao emprego de INFflex em PB e trata das questões específicas a que esta tese se propõe a responder, além de estabelecer as bases teóricas deste estudo. 


\section{2 \\ Pressupostos teóricos}

A revisão da literatura sobre INFflex em PB e em PE, tal como foi desenvolvida no capítulo anterior, leva a várias questões que ainda carecem de respostas, tais como: (1) Atualmente, qual é o padrão de usos de INFflex e INFØ? (2) Em contextos sintáticos considerados opcionais, qual das duas formas é preferida? (3) Nesses mesmos contextos opcionais, há tendência de aumento no emprego de INFflex na escrita culta? (4) O emprego de INFflex em contextos não padrão, como nos complementos de verbos auxiliares, estaria relacionado à frequência de INFflex nos contextos opcionais? (5) Considerando-se o prestígio geralmente associado à concordância verbal em PB, estaria em curso um processo de extensão desse valor social positivo para o emprego de INFflex? Dentre essas, a presente pesquisa se ocupa das questões 2, 3 e 5 . Dessa forma, esta tese tem dois interesses centrais: (i) analisar quantitativamente o emprego de INFflex em contextos opcionais nos últimos anos e (ii) investigar se significados sociais positivos estão associados a INFflex.

\section{$2.1 \quad$ Proposta}

Para responder às questões 2 e 3, investiga-se, a partir dos resultados encontrados por Canever (2012) em um corpus de teses da área de Letras da USP, a variação no emprego de INFflex em um corpus formado por 1346 teses produzidas por alunos de diferentes unidades de USP ao longo de 20 anos. $^{1}$

1 Utilizaram-se teses da USP devido à facilidade de acesso online a um número alto de teses através do Banco de Teses da USP. 
Analisa-se, portanto, o emprego de INFflex em contextos opcionais na escrita padrão. Interessa (i) verificar se os padrões encontrados por Canever em teses da área de Letras se mantêm em teses de diferentes áreas, (ii) verificar se houve aumento no emprego de INFflex nos 20 anos investigados (1995 a 2014) e (iii) comparar as tendências de usos de pós-graduandos das diferentes áreas do conhecimento. A hipótese é de que serão encontradas maiores taxas de INFflex nos últimos anos, ou seja, espera-se que as taxas de INFflex em contextos opcionais tenham aumentado. Em relação aos padrões de uso entre as áreas, espera-se que sejam encontradas maiores taxas de INFflex em teses da área de Humanas.

Dentre os contextos facultativos apresentados no quadro sinóptico de Maurer Jr. (1968), analisa-se, neste estudo, a variação no emprego variável de INFflex nos três contextos sintáticos opcionais "originais" (Bossaglia, $2013 a: 27)$ : orações adverbiais ( 1 - 3), complementos de adjetivos (4 e 5), e complementos de nomes (7 e 6). Nesses contextos, Canever (2012) encontrou as seguintes taxas: $75 \%$ de INFflex em orações adverbiais $(\mathrm{N}=525) ; 53,5 \%$ de INFflex em complementos de adjetivos $(\mathrm{N}=101)$ e $94,5 \%$ de INFflex em complementos de nomes $(\mathrm{N}=54)$.

(1) No caso das palavras com artigo definido, ocorreram por serem monossílabos. $(\text { filo_2 })^{2}$

(2) Escolhemos o termo "eixo" por considerarmos que ele é ao mesmo ... (fran_10)

(3) ... quando pai e filho se juntaram para formularem um acordo. (lp_6)

(4) ... mostram ritmos próprios, capazes de imprimir, no ânimo do ouvinte, sensações ... (class_8)

(5) ... categorias referidas eram muito vagas, variáveis difíceis de serem controladas. (dlo_9)

(6) ... jornais e têm o propósito de chamar a atenção do leitor. (filo_21)

(7) ... contam, sob o pretexto de trazerem um presente, com o qual fingia que

2 Assim como os exemplos apresentados na seção 1.4 .2 do capítulo 1 , os exemplos de 1 a 6 são do Corpus PósLetrasUsp, tendo sido extraídos de teses da área de Filologia (filo), Francês (fran), Língua Portuguesa (lp), Departamento de Letras Orientais (dlo) e Estudos Clássicos (class). 
o rei pudesse ser ... (class_22)

Para responder à questão 5 , realiza-se um experimento de percepção sociolinguística, baseado na técnica de estímulos pareados (Lambert et al., 1960; Mendes, 2016b; Oushiro, 2015), ${ }^{3}$ com o objetivo de verificar se falantes são percebidos como "mais inteligentes", "mais escolarizadas" e "mais formais" quando ouvidos utilizando a variante INFflex. Testa-se, ainda, se falantes são percebidos de modo diferente a depender dos contextos nos quais INFflex ou INFØ ocorre - se em contextos opcionais, tais como em orações adverbiais, ou em contextos de hipercorreção, tais como complementos de verbos modais.

Delineada a proposta deste estudo, apresentam-se, a seguir, suas bases teóricas.

\subsection{Sociolínguistica e modelos baseados no uso}

Este é um estudo essencialmente variacionista, uma vez que lida com duas variantes linguísticas - INFflex e INF $\varnothing$ - no contexto variável definido com base na proposta de Bossaglia (2013a) acerca dos contextos sintáticos nos quais INFflex teria se originado.

Pensado inicialmente para o estudo da variação no nível fonológico, o conceito de regra variável, central aos estudos variacionistas, foi proposto no contexto da fonologia gerativa (Guy, 2014; Walker, 2012), representando uma tentativa de incorporação do estudo da variação e da mudança no quadro da teoria linguística formal (Fasold, 1991; Walker, 2012). Análises variacionistas, no entanto, não exigem que se partam dos mesmos pressupostos de uma teoria formal (Walker, 2012 : 398). Além disso, a noção de regra variável pode ser usada na análise da variação nos diferentes níveis linguísticos como um dispositivo heurístico (Fasold, 1991; Lavandera, 1978; Walker, 2012). ${ }^{4}$ Nesse sentido, utiliza-se, nesta tese, o conceito de regra variável como instrumento

3 Matched-guise technique.

4 Lavandera (1978) questiona a extensão da noção de regra variável fora do domínio da fonologia, uma vez que não se pode afirmar que variantes morfológicas, lexicais ou sintáticas são idênticas em valor de verdade, ou seja, não se pode afirmar que são modos diversos de dizer a mesma coisa. Para ela, regras variáveis podem servir, porém, como dispositivos heurísticos (heuristic devices). 
analítico e adotam-se os pressupostos das teorias baseadas no uso. ${ }^{5}$ Trata-se, portanto, de um estudo que se insere no campo da Sociolinguística Cognitiva (Ferrari, 2016:137). ${ }^{6}$

Convém destacar a diferença entre metodologias baseadas no uso e teorias baseadas no uso: nas primeiras, utilizam-se dados de língua em uso (em oposição a dados de introspecção), enquanto as teorias baseadas no uso dizem respeito a uma visão de língua que emerge do uso. Assim, metodologicamente, a sociolinguística é sempre baseada no uso, mesmo quando feita à luz de pressupostos teóricos formalistas.

Teorias baseadas no uso, em vez de postular a existência de módulos linguísticos independentes e regras abstratas e inatas, propõem que o conhecimento linguístico é construído, por meio de habilidades cognitivas gerais, $a$ partir do uso (Bybee, 1985, 2006a,b, 2010; Langacker, 1987, 2000). Indivíduos, dotados da habilidade cognitiva de esquematização - um tipo especial de capacidade de abstração (Langacker, 2000) -, fazem generalizações e extraem esquemas abstratos a partir de experiências linguísticas recorrentes. Assim, através da experiência com a língua, armazenam-se tanto os padrões mais abstratos emergentes - os esquemas de nível mais alto - quanto esquemas mais próximos das ocorrências concretas a partir das quais os padrões emergem - as instâncias ou esquemas de níveis mais baixos (Langacker, 2000:3)-, constituindo o que se entende por um modelo de baixo para cima (bottom-up) e uma proposta não-reducionista e redundante. ${ }^{7}$

Em uma tentativa de ilustrar o que seria uma gramática baseada no uso, Kemmer \& Israel (1994) propuseram o seguinte diagrama:

5 Usage-based Theories.

6 Ferrari fala em Sociolinguística Cognitiva partindo do fato de que teorias baseadas no uso foram propostas no âmbito da Linguística Cognitiva. No entanto, segundo Cezario et al. (2016:50), este estudo também poderia ser inserido no campo do Sociofuncionalismo, que se baseia "nos pressupostos da Sociolinguística variacionista e do Funcionalismo norte-americano ou, mais recentemente, da Linguística Funcional Centrada no Uso", essa última uma das traduções de usage-based linguistics adotadas no cenário brasileiro.

7 Em modelos reducionistas, apenas as regras mais gerais são armazenadas no "sistema" (Langacker, $1988: 264)$. 


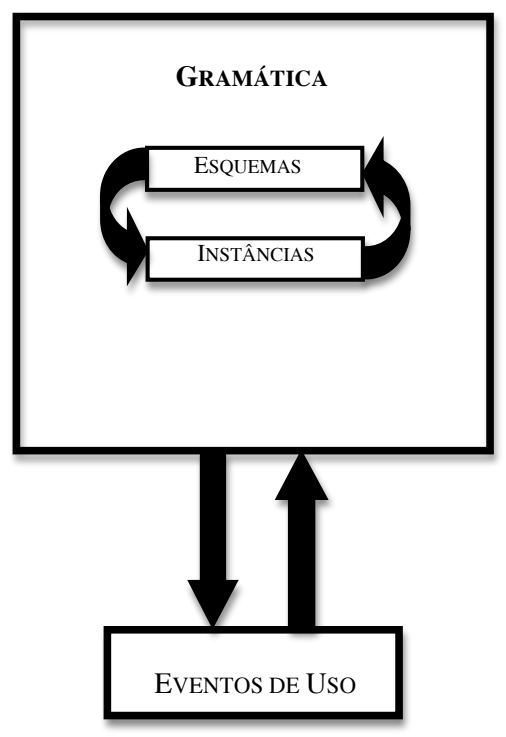

Figura 2.1 Uma gramática baseada no uso segundo Kemmer \& Israel (1994)

O quadrado da gramática representa o inventário linguístico (Langacker, 2000), ${ }^{8}$ no qual são armazenados os esquemas e as instâncias que emergem a partir dos eventos de uso. As flechas pretendem capturar a relação de interdependência que existe entre as estruturas armazenadas na gramática e o uso da língua, bem como entre as instâncias e os esquemas.

Uma proposta de adaptação do diagrama de Kemmer \& Israel (1994) que procurou enfatizar a dinamicidade central às gramáticas baseada no uso foi apresentada por Canever (2012), pensando nos dados de INFflex e INFØ:

\footnotetext{
8 Embora o termo "inventário", que Langacker (2000) usa para se referir ao conhecimento linguístico armazenado, possa sugerir algo estático, esse deve ser interpretado como um estoque dinâmico.
} 


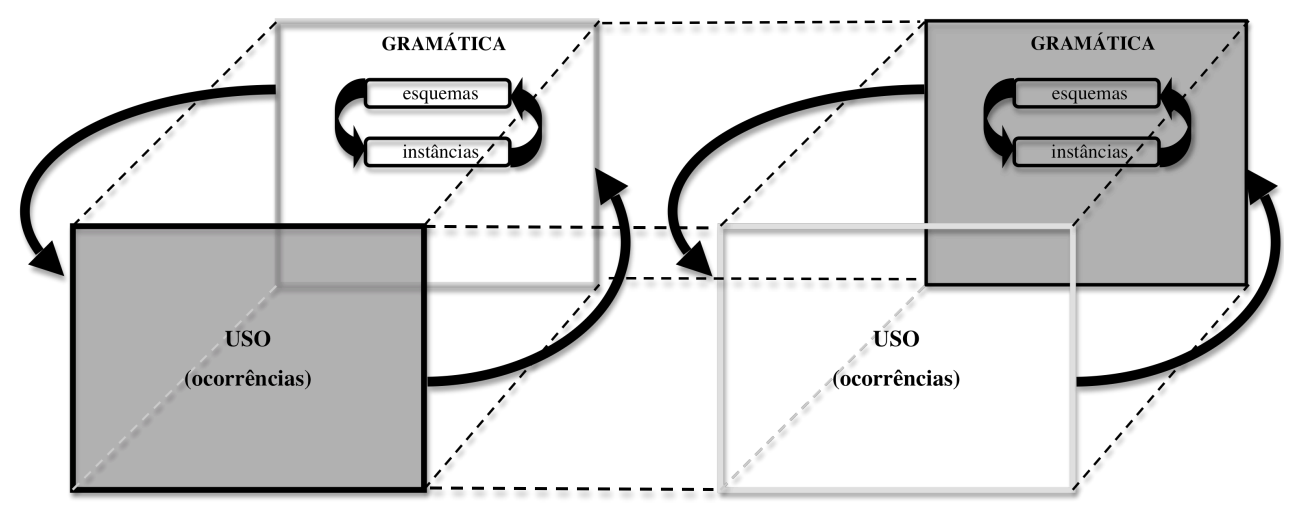

Figura 2.2 Adaptação do diagrama de Kemmer \& Israel (1994) apresentada por Canever (2012)

Diferentemente da figura 2.1, que traz uso e gramática em tamanhos diferentes, na figura 2.2, essas "facetas" têm o mesmo tamanho e formam um todo dinâmico, que pode ser visto de diferentes ângulos. A cor cinza que preenche os quadrados indica diferenças no grau de saliência: a gramática parece mais saliente do que o uso ou o uso parece mais saliente que a gramática a depender do foco do pesquisador. O que se pretende enfatizar com as flechas maiores é o processo de realimentação entre ocorrências concretas e as estruturas armazenadas: "a gramática serve de base para o uso enquanto o uso serve de base para a formação e atualização da gramática" (Canever, 2012). É contínua, portanto, a atualização do conhecimento linguístico a partir do uso.

Joan Bybee, que já advogava a favor de um enfoque "baseado no uso" antes mesmo de o termo ser cunhado por Langacker (1987), ${ }^{9}$ afirma que, "embora todos os linguistas provavelmente concordem que a gramática é a organização cognitiva da língua, teóricos baseados no uso fazem a proposta mais específica de que a gramática é a organização cognitiva da experiência individual com a língua" (Bybee, 2006b:712 - grifo próprio). ${ }^{10}$ Valendo-se

\footnotetext{
9 Langacker considera visionário o trabalho desenvolvido por Joan Bybee (Langacker, 2000:46), que define o modelo baseado no uso como um paradigma de pesquisa amplo que engloba o funcionalismo e a linguística cognitiva. Bybee (2006b) explica que a base do que hoje se conhece por modelo baseado no uso é formada por trabalhos desenvolvidos por ela e por funcionalistas tais como Joseph Greenberg, Paul Hopper, Sandra Thompson e Talmy Givón, que já reconheciam que o estudo da estrutura linguística não deveria ser isolado do uso da língua. Além deles, Bybee cita sociolinguistas, tais como William Labov, Gillian Sankoff e Shana Poplack, que sempre se basearam em dados da fala natural para estudar a inerente variação linguística.

10 Original: "While all linguists are likely to agree that grammar is the cognitive organization of language,
} 
do conceito de exemplares proposto na psicologia - inicialmente adotado na Linguística como modo de representar a variação fonética (Pierrehumbert, 2001)-, a autora entende que a gramática é formada por uma vasta rede de conexões entre representações cognitivas, que, apesar de abstratas, apresentam uma forte conexão com a experiência concreta: ${ }^{11}$

"Exemplares são ricas representações da memória; eles contêm, ainda que em potencial, toda a informação que um usuário da língua pode perceber em uma experiência linguística. Essa informação inclui detalhes fonéticos, inclusive traços redundantes e variáveis, itens lexicais e construções utilizadas, o significado, inferências feitas a partir desse significado e a partir do contexto, e propriedade do contexto social, físico e linguístico." (Bybee, 2010:12)

A possibilidade de serem armazenadas e atualizadas, a cada evento de uso, também informações de natureza sociolinguística relacionadas às variantes linguísticas é de particular interesse à Sociolinguística. Segundo Walker (2012 : 398), outro fator de teorias baseadas no uso que atrai variacionistas é a natureza inerentemente quantitativa desses modelos: neles, tanto a frequência de ocorrência (token frequency) quanto a frequência de um padrão (type frequency) desempenham papéis centrais na dinâmica de uma gramática baseada no uso e no processamento linguístico (Bybee, 1985, 2006a,b, 2010).

Ricas em detalhes, as representações linguísticas armazenadas nas gramáticas individuais são impactadas a cada experiência com a língua: caso haja na memória do falante um exemplar idêntico às instâncias linguísticas concretas com as quais o falante tem contato, tais instâncias são mapeadas no exemplar existente, fortalecendo-o; caso o falante tenha contato com instâncias linguísticas que são apenas similares - não idênticas - a algum exemplar existente, elas são representadas como um novo exemplar, que é, então, armazenado próximo aos exemplares similares, formando categorias ou agrupamentos

a usage-based theorist would make the more specific proposal that grammar is the cognitive organization of one's experience with language."

11 Assim com as instâncias, esquemas de nível mais baixo aos quais Langacker (2000) se refere.

12 Original: "Exemplar representations are rich memory representations; they contain, at least potentially, all the information a language user can perceive in a linguistic experience. This information consists of phonetic detail, including redundant and variable features, the lexical itens and constructions used, the meaning, inferences made from this meaning and from the context, and properties of the social, physical and linguistic context." 
(Bybee, 2006b : 718). Desse modo, a frequência de ocorrência de instâncias de uso linguístico desempenha um papel fundamental no fortalecimento cognitivo das estruturas linguísticas. ${ }^{13}$

Bybee (2006b : 727) explica que a rede de exemplares pode ser reorganizada a partir de exemplares mais frequentes e usa como exemplo desse processo a construção be going to do inglês, usada atualmente tanto para expressar "movimento no espaço" quanto "intenção":

"Se uma certa inferência pragmática, tal como a intenção no exemplo de 'going to', ocorre muito frequentemente no agrupamento de exemplares semânticos com uma certa forma, esse significado pode se tornar fortemente associado à forma e fazer com ele apareça em novos contextos, tais como aqueles que significam intenção, mas não movimento." (Bybee, 2006b : 727 - grifo próprio) ${ }^{14}$

Desse modo, é plausível supor que, no caso do emprego variável de INFflex, a expansão do uso da forma flexionada para novos contextos sintáticos de infinitivo (Maurer Jr., 1968) esteja relacionada ao fortalecimento cognitivo de exemplares de INFflex. No entanto, Blythe \& Croft (2012) advertem que a questão da propagação de usos inovadores, tais como o emprego de INFflex em novos contextos sintáticos, não envolve apenas efeitos de frequência. Esses autores entendem que, levando-se em conta apenas a sua frequência, todas as inovações, por apresentarem uma natural baixa frequência de ocorrência - exemplares fracos -, tenderiam a ser vencidas pelas formas linguísticas já estabelecidas e com forte arraigamento cognitivo na gramática dos falantes. Sabe-se, porém, que certas construções linguísticas inovadoras se propagam, se estabelecem como variantes, podendo, inclusive, tornar-se as variantes padrão e, eventualmente, substituir as demais variantes, configurando processos de mudança linguística. Sendo assim, se a frequência não é suficiente para explicar tais processos, necessariamente estão envolvidos fatores de natureza social (Blythe \& Croft, 2012).

\footnotetext{
13 Equivalente ao conceito de arraigamento cognitivo discutido por Langacker, Bybee utiliza os termos lexical strength e autonomy para se referir ao fortalecimento cognitivo das estruturas. Ambos, porém, estão relacionados à habilidade cognitiva de automatização do comportamento.

14 Original: "If a particular pragmatic inference, such as intention in the be going to example, occurs very frequently in the semantic cluster of exemplars with a particular form, that meaning can become firmly associated with the form and cause it to show up in new contexts, such as those in which intention, but no movement in space, is signified."
} 
Entre os trabalhos de orientação baseada no uso que levam em conta fatores sociais, tais como a valoração social das variantes linguísticas - e aos quais se alinha o presente estudo -, além de Blythe \& Croft (2012), há Blythe \& Croft (2010) e Baxter \& Croft (2016), que partem da teoria de seleção de enunciados ${ }^{15}$ proposta por Croft (2000). A seção seguinte é dedicada a tais trabalhos.

\section{Sobre a propagação de variantes linguísticas}

A teoria de mudança linguística proposta por Croft (2000) é inspirada na Análise generalizada da seleção de Hull (1988), filósofo da ciência que explica, nos termos de teorias evolucionárias, como os conceitos científicos mudam. Nessas teorias, a mudança é vista como resultado da replicação de entidades de tal modo que as entidades resultantes retêm toda ou grande parte da estrutura das originais. Fala-se em replicação normal quando as entidades copiadas são idênticas às originais, em replicação alterada quando há a geração de variação no processo de replicação e em replicação diferencial quando acontece a seleção (ou propagação) de variantes (Croft, 2000). Considerado em algumas linhas apenas o veículo para a replicação do replicador, o interator, do modo como propõe Hull, é a entidade que interage com o ambiente de modo a causar replicação diferencial dos replicadores, desempenhando, assim, um papel importante no processo de mudança. À luz dessas ideias, Hull propõe, então, que os conceitos científicos são replicadores, os cientistas são os interatores e, uma vez gerada a variação no processo de replicação dos conceitos, a replicação diferencial se dá através de publicações, palestras e aulas.

Seguindo Hull, Croft aplica esses mesmos conceitos na explicação da mudança linguística: os falantes, que são os interatores, replicam linguemas estruturas linguísticas - na interação com outros falantes; a população em que a replicação de linguemas acontece é a comunidade de fala; e o ambiente inclui tanto o evento de fala em si, quanto os objetivos interacionais e os outros membros da população. Assim, nessa visão, a mudança linguística

\footnotetext{
15 Original: Theory of utterance selection.
} 
acontece por meio da replicação de linguemas, entidades empiricamente reais empregadas pelos falantes para atingir seus objetivos sociointeracionais:

"A replicação de linguemas nos enunciados é fundamentalmente um processo cognitivo, mediado pela ativação de alguma estrutura mental e rotina motora-articulatória. (Essa estrutura mental/ rotina mental é adquirida pela exposição a ocorrências prévias do linguema no uso da língua). E a replicação de linguemas é igualmente um processo social, mediado pelo falante na interação verbal. Se um falante não fala, ele não replica linguemas." (Croft, $2000: 30)^{16}$

Aplicando os três modos de replicação propostos na teoria de mudança evolucionária, Croft entende que, no caso da língua, a replicação é normal quando há conformação ao que é convencional na comunidade de fala, alterada quando emergem inovações, e diferencial quando inovações são selecionadas por outros membros da comunidade de fala. Para o autor, a replicação alterada é o primeiro passo para a mudança linguística, uma vez que é a partir dela que novas variantes se tornam disponíveis para outros falantes. A respeito do que chama de "geração de variação" Croft (2000), o autor rechaça a ideia de que estejam envolvidos mecanismos teleológicos - ou seja, que os falantes produzam inovações com o objetivo de modificar a língua e defende que as inovações emergem em função de fatores como busca por maior expressidade ou mais clareza. ${ }^{17}$ Uma vez gerada a variação através da replicação alterada, as novas variantes disponíveis podem ser adotadas ou propagadas em uma comunidade de fala a depender de fatores sociais:

"Os falantes selecionam as variantes que vão empregar - isto é, replicar - em determinados enunciados com base no valor social dessas variantes: prestígio ou prestígio encoberto, relação social do falante com seu interlocutor, etc. (...) Em outras palavras, são os fatores sociais, e não os funcionais, que desempenham, na seleção das variantes linguísticas, o papel que os fatores ecológicos desempenham na biologia. (...) A alteração nas proporções de variantes de uma variável linguística no uso

\footnotetext{
16 Original: Replication of linguemes in utterances is fundamentally a cognitive process, mediated by activation of some mental structure and articulatory motor routine. (This mental structure/ mental routine is of course acquired from exposure to prior occurrences of the linguemes in language use.) And replication of linguemes is equally fundamentally a social process, mediated by the speaker in conversational interaction. If a speaker doesn't speak, she will not replicate any linguemes.

17 Para o autor, pressões funcionais estão presentes apenas na geração da variação e não na propagação das inovações entre falantes de uma comunidade de fala
} 
é ocasionada pela alteração no grau de arraigamento de tais variantes nas gramáticas dos falantes. Essa alteração é resultado do valor social dessas variantes para falantes individuais, mas o efeito global é um ajuste de seu valor de ativação, ou uma alteração em seu arraigamento na gramática dos falantes" (Croft, $2000: 32$ - grifo próprio). ${ }^{18}$

Ao sublinhar a importância do valor social atribuído às variantes, Croft evidencia o caráter sociolinguístico de sua proposta, que se alinha aos estudos da significação social da variação, especialmente àqueles desenvolvidos no que atualmente se denomina terceira onda da Sociolinguística (Campbell-Kibler, 2008, 2009; Eckert, 2005, 2008, 2012).

Segundo Eckert (2005, 2012), os estudos sociolinguísticos organizam-se em três ondas, que representam modos distintos de ver a variação e nas quais se empregam diferentes metodologias. Enquanto estudos de primeira onda focalizam o nível macrossocial da variação e demonstram a distribuição das variantes linguísticas entre categorias demográficas amplas (Eckert, 2005:4), estudos de segunda onda focalizam categorias dinâmicas mais locais e investigam a natureza do significado social em estruturas locais, tais como comunidades de prática. Estudos de terceira onda, por sua vez, focalizam a variação no nível microssocial e investigam como a variação produz e adquire significado social na atividade linguística diária (Eckert, 2008:472). Uma das especificidades da terceira onda é a consideração de que os significados sociais das variantes linguísticas são, eles próprios, variáveis e mutáveis, para uma mesma comunidade (de fala, de práticas e de falantes, individualmente considerados). O experimento de percepção sociolinguística baseado na técnica de estímulos pareados, tal como o que aqui se realiza (ver capítulo 5), é um método frequentemente utilizado em estudos de terceira onda. Já o estudo quantitativo da variação de INFflex a partir do corpus de teses pode ser considerado um estudo que se assemelha aos de primeira onda, dado o interesse em padrões gerais de variação.

\footnotetext{
18 Original: Speakers select variants to use - that is, to replicate - in particular utterances on the basis of their social values: overt ou covert prestige, the social relation of the speaker to the interlocutor, etc.(...) The shift in proportions of the variants of a linguistic variable in usage is brought about by shifts in degrees of entrenchment of those variants in the grammars of the speakers. This shift is a result of the social value of those variants for individual speakers, but the global effect is an adjustment of their activation value, or a shift in their entrenchment, in a speaker's grammar.
} 
A investigação do significado social da variação linguística a partir de diferentes ângulos é importante, porque "variáveis são, em princípio, associadas a significados bastante abstratos, derivados de padrões de larga-escala em comunidades estratificadas e sobrepostas (imaginadas ou não)", ${ }^{19}$ adquirindo significados mais locais à medida que são utilizadas (Eckert, 2005 : 5). Sendo assim, o significado social associado às variantes linguísticas, armazenado cognitivamente nos exemplares, é algo dinâmico que, a cada experiência linguística, é reforçado, reformulado ou enfraquecido.

A forma como tais questões sobre o valor social da variação se relacionam com a propagação de variantes linguísticas fica clara na seguinte tipologia proposta por Baxter et al. (2009):

- Mecanismo de evolução neutra ${ }^{20}$

A propagação depende meramente da frequência de ocorrência da variante linguística.

- Mecanismo de seleção pela frequência de interação ${ }^{21}$

A frequência de interação com interatores - falantes - que empregam a variante determina se ela vai ser propagada ou não. Em conformidade com estruturas de redes sociais, alguns membros de uma comunidade de fala interagem mais com certos membros do que com outros, e, como resultado disso, são expostos a diferentes frequências de ocorrência das variantes. Valores sociais não estão envolvidos nesse mecanismo.

- Mecanismo de seleção pelo peso dado ao interator ${ }^{22}$

A propagação da variante depende do valor social atribuído ao interator. Nem todos os interatores impactam a seleção da mesma forma: alguns falantes são mais valorizados socialmente do que outros.

- Mecanismo de seleção pelo replicador ${ }^{23}$

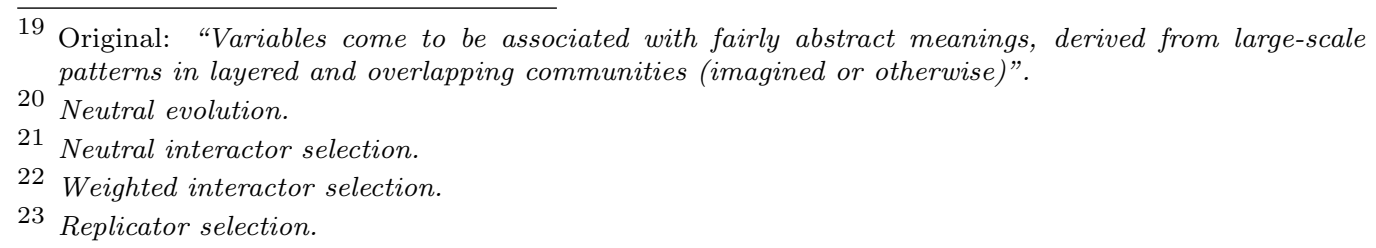


A propagação depende do valor atribuído à variante (ex. prestígio).

Com base nessa tipologia, Baxter et al. (2009) modelaram matematicamente a proposta de Trudgill (2004) sobre a emergência do inglês da Nova Zelândia. O processo de formação dessa variedade linguística, segundo Trudgill, pode ser explicado pela frequência de uso das variantes e a frequência de interação com falantes que utilizam tais variantes. Em sua proposta, portanto, apenas os dois primeiros mecanismos propostos por Baxter et al. (2009) estão em jogo: as variantes mais frequentes e às quais se é mais frequentemente exposto necessariamente se estabelecem como as variantes padrão, sem que algum valor social esteja envolvido no processo de seleção. No entanto, a partir dos resultados de simulações matemáticas, Baxter et al. (2009) concluem que, embora importante, a frequência é insuficiente para explicar a emergência de um novo dialeto em uma sociedade isolada, tal como proposto por Trudgill e sugerido pela evidência da história do inglês da Nova Zelândia (Baxter et al., 2009: 390). Segundo esses autores, é necessário adicionar aos modelos matemáticos pelo menos um dos mecanismos que envolvem valores sociais seleção pelo peso dado ao interator e/ou seleção pelo replicador.

Nessa mesma linha, Blythe \& Croft (2012) utilizaram modelos matemáticos para verificar quais dos mecanismos propostos por Baxter et al. (2009) precisariam estar presentes para explicar mudanças linguísticas que envolvem a substituição de uma variante por uma variante inovadora e que seguem uma curva em S, ${ }^{24}$ tal como se vê no gráfico 2.3, extraído de Blythe \& Croft (2012), feito com base em dados de Poplack \& Malvar (2007).

${ }^{24}$ S-curve. 


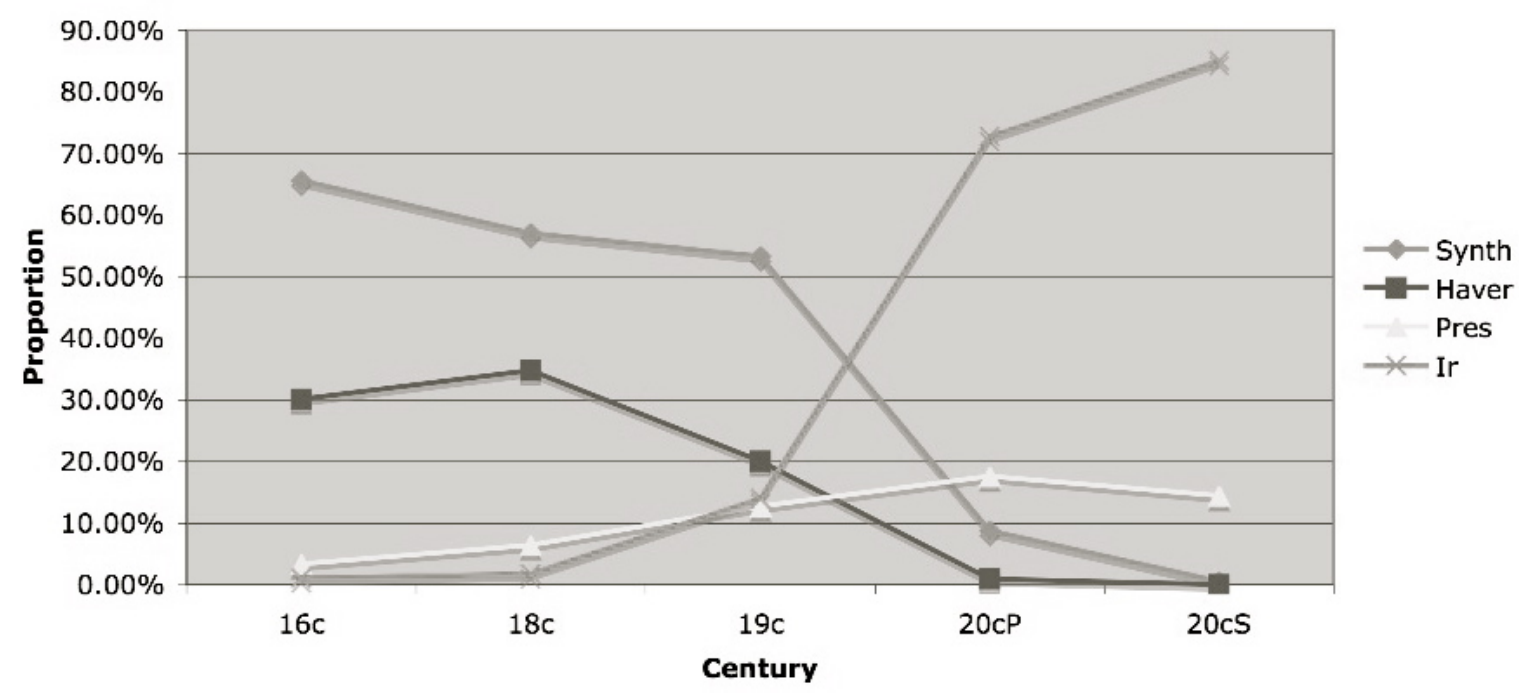

Figura 2.3 Trajetória da evolução das variantes de futuro no português brasileiro. Extraído de Blythe \& Croft (2012)

O gráfico mostra a trajetória das 4 variantes de futuro no português brasileiro: o futuro sintético (8), a perífrase com haver (9), o presente (10) e a perífrase com ir (11):

(8) Que impertinência! Logo conversaremos. (Poplack \& Malvar, 2007 : 150)

(9) Pois aonde o hei de pôr? (Poplack \& Malvar, 2007:146)

(10) O livro que te prometi, mando amanhã. (Poplack \& Malvar, 2007 : 149)

(11) Ninguém vai saber. Você sabe. A imprensa só publica o que deixam publicar. (Poplack \& Malvar, 2007 : 142)

Blythe \& Croft (2012) concluem que, para a produção de uma trajetória em $\mathrm{S}$ - tal como a que segue a variante de futuro 'perífrase com ir' em PB - é essencial a diferenciação na valoração social das variantes linguísticas.

Tais tentativas de formalização matemática com base em dados de língua em uso representam um avanço importante no estudo da natureza dinâmica da língua, uma vez que oferecem sustentação empírica às propostas de que tanto a frequência quanto fatores sociais são essenciais em processos de variação e mudança linguísticas, tais como as que se adotam neste estudo. 


\section{Hipercorreção}

Labov (1972) apresenta como um fator de mudança linguística o processo de hipercorreção, cujo clássico exemplo é o emprego do sintagma you and I em posição de objeto, como em:

(12) 'The possible misunderstanding between you and I'.

Prescritivamente, you and I é gramatical apenas como sujeito e, quando empregado como objeto, considera-se um uso hipercorrigido. Conforme explica Labov (1972), a hipercorreção é fruto da insegurança linguística sobretudo de falantes da classe média baixa que tendem a procurar falar como falantes mais prestigiosos da classe média alta. Para Labov (1972:171), as mães da classe média e as professoras primárias tendem a ser agentes principais em processos de hipercorreção. Assim, alguns falantes, independentemente de sua classe social, são frequentemente expostos a usos hipercorrigidos e crescem com a intuição de que tais usos são gramaticais e socialmente "bons", deixando de apresentar a mesma insegurança linguística inicial dos hipercorretores, que resultou na emergência da forma hipercorrigida. Nesse cenário, portanto, existem 3 categorias de falantes: o hipercorretores da classe média baixa, os falantes da classe média alta que falam a língua-alvo, que não são afetados pelo processo, e a geração mais jovem que adquire a nova variedade vernacular que inclui o emprego hipercorrigido.

Hock \& Joseph (1996 apud Boyland 2001), que investigaram o uso hipercorrigido de you and $I$, acreditam que a correção explícita pode impactar as crenças que os falantes têm a respeito de quais formas linguísticas são corretas. Assim, falantes jovens que crescem sendo corrigidos ao dizer algo como "Charlie and me went to the movies", generalizam essa correção explícita de tal modo que passam a acreditar que a forma Charlie and me é sempre incorreta prescritivamente. Como consequência da frequente correção explícita, a ideia de que a forma you and $I$ é a correta vai se solidificando de modo que esses falantes passam a acreditar que essa é a forma correta em todos os casos.

Tais efeitos da correção explícita são particularmente relevantes para esta tese. Considerando-se que os autores das teses investigadas apresentam 
alto nível de escolaridade, pode-se supor que todos eles foram expostos, por muitos anos, se não à correção explícita, certamente ao discurso normativo que enfatiza a marcação de plural no uso padrão do PB. Sendo assim, na linha do que propõem Hock \& Joseph (1996 apud Boyland 2001), é plausível imaginar que as crenças desses falantes sobre o que é "correto" no que diz respeito à marcação de plural podem incluir generalizações que resultam em maiores taxas de INFflex nos contextos opcionais e levam a usos redundantes e hipercorrigidos de INFflex, tais como:

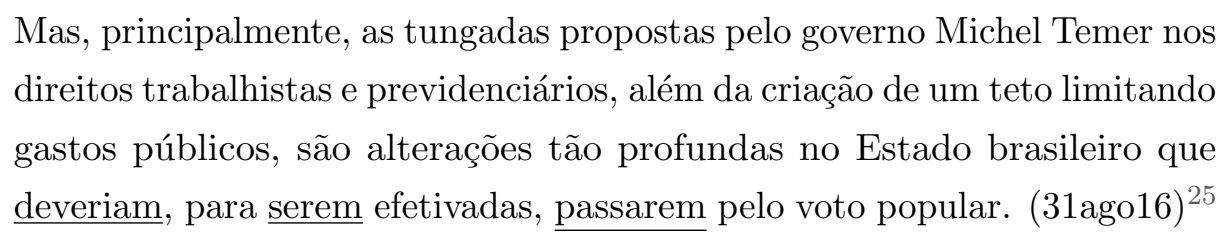

Giles \& Williams (1992) discutem a hipercorreção que ocorre por razões pragmáticas - e não por insegurança linguística ou crenças metalinguísticas. De acordo com a teoria de acomodação comunicativa proposta por esses autores, falantes mudam sua fala para enfatizar ou minimizar as diferenças sociais entre eles e seus interlocutores, em uma espécie de escolha consciente com fins interacionais. Nesse modelo, falantes normalmente tomados como prestigiosos também fazem usos hipercorrigidos. Boyland (2001) entende, no entanto, que esse modelo explica apenas mudanças na "performance" e não na "competência", deixando em aberto a questão de como falantes que detêm prestígio em uma comunidade passam a ver determinadas formas como corretas ou aceitáveis.

Interessada em testar os limites das propostas de hipercorreção como um mecanismo importante nos processos de variação e mudança linguística, Boyland (2001) também investigou o uso hipercorrigido de you and I. Por meio de um teste de aceitabilidade, a autora chegou a resultados que apontam para a existência de uma quarta categoria envolvida no processo de hipercorreção: a de falantes de prestígio que utilizam formas não-padrão embora acreditem que estejam usando as formas prescritas.

\footnotetext{
25 Exemplo extraído pela autora de um comentários em um site de notícias na data indicada.
} 
Além disso, em consonância com o que Bybee (2006b, 2010) propõe em relação ao impacto que exemplares com alto grau de fortalecimento cognitivo podem ter na rede de exemplares armazenados, Boyland constatou, por meio de um estudo de corpus, que um fator determinante na propagação de uma forma de prestígio para contextos não-padrão é sua frequência em seu contexto original. Nesse sentido, é possível que haja uma correlação entre a frequência de uso de INFflex em contextos padrão - e até mesmo em contextos opcionais - e usos hipercorrigidos dessa variante linguística. É possível, ainda, que verbos que apresentam taxas mais altas de INFflex sejam mais frequentemente empregados de modo hipercorrigido.

Sendo assim, o estudo de Boyland tem duas contribuições importantes: (i) confirma a existência de uma quarta categoria - a de falantes de prestígio também hipercorrigem e (ii) oferece evidências de que processos cognitivos baseados em frequência são capazes de alterar a intuição linguística desses falantes. ${ }^{26}$

Além de demonstrar que considerar a frequência de uso é indispensável para o estudo da propagação de formas hipercorrigidas, esses achados de Boyland interessam a esta tese na medida em que demonstram que falantes de prestígio, tais como os autores das teses aqui investigadas, também hipercorrigem.

\section{Concordância de número no português brasileiro}

Presente na "consciência pública" (Naro \& Scherre, 2013:2), a variação na concordância de número no português brasileiro é um fenômeno que desperta fortes sentimentos naqueles preocupados com o que consideram "declínio" ou "deteriorização" da língua (Cameron, 1995; Scherre \& Naro, 2014). Tanto no caso da concordância nominal quanto no caso da verbal, a marcação explícita de plural é detentora de prestígio, ao passo que é estigmatizada e associada à ideia de "não saber falar português" a marca zero do plural, tal como nos exemplos 14 e 15 :

\footnotetext{
$\overline{26}$ A aceitabilidade gradual de construções altamente frequentes, que reflete uma mudança na intuição dos falantes, foi investigada e confirmada por Luka \& Barsalou (1998 apud Boyland 2001), em um dos poucos estudos a respeito das mudanças dos julgamentos gramaticais entre falantes adultos. Segundo os autores, a exposição frequente a determinadas construções as tornam cada vez mais naturais.
} 
(14) As meninaØ do bairro.

(15) Nós vaiØ lá.

Considerando-se o estigma social associado às marcas zero, tais formas tendem a ser desfavorecidas em estilos mais monitorados, ou seja, quando há um maior grau de atenção prestado à própria fala (Labov, 1972). Além disso, estudos apontam para o favorecimento da marcação explícita quanto maior o grau de escolaridade do falante (Brandão \& Vieira 2012; Gorski 2000; Mendes \& Oushiro 2015; Naro \& Scherre 2013; Oushiro 2015; Rubio \& Gonçalves 2012, inter alia). ${ }^{27}$ Em relação a essa variável, Rubio \& Gonçalves (2012) verificaram uma influência direta do nível de escolaridade no emprego variável da concordância verbal de 1PP com o pronome nós.

Uma maior tendência à marcação explícita de plural também tem sido verificada quando são salientes as diferenças entre a forma singular e a forma plural, demonstrando o efeito significativo da variável saliência fônica (Naro \& Scherre, 1991): diferenças menos salientes, por sua vez, favorecem as marcas zero.

No que diz respeito especificamente à variação na concordância verbal, tem se mostrado uma variável significativa a posição do sujeito: a marcação do plural é fortemente favorecida com sujeitos imediatamente precedentes ao verbo, levemente desfavorecida com sujeitos precedentes distantes, e fortemente desfavorecida quando os sujeitos aparecem pospostos ao verbo (Brandão \& Vieira, 2012; Mendes \& Oushiro, 2015; Naro \& Scherre, 2013; Oushiro, 2015; Rubio \& Gonçalves, 2012). Tais resultados são interessantes para o estudo do emprego variável da marcal de plural no infinitivo (INFflex) na medida em que se contrapõem à ideia de que, em casos de correferencialidade, a distância entre o infinitivo e seu sujeito favorece o emprego da flexão, como entendem Vanderschueren (2013); Vanderschueren \& de Cuypere (2014); Vanderschueren \& Diependaele (2013); Vesterinen (2006). Partindo dos achados desses estudos sociolinguísticos, pode-se supor que quanto maior a proximidade entre

\footnotetext{
$\overline{27}$ Vale destacar que a grande maioria dos estudos sobre concordância verbal no PB se debruçam sobre os casos de verbo finito - e muitas vezes não deixam claro o que foi feito com casos de infinitivo flexionado. Gorski (2000) é um dos poucos estudos que se debruça sobre o infinitivo flexionado e o faz analisando dados de língua falada.
} 
o infinitivo e o sujeito, maior a tendência ao emprego de INFflex.

Outra variável que tem se mostrado significativa em estudos sociolinguísticos sobre a concordância de número e que é de extrema relevância para a análise do emprego variável de INFflex é o paralelismo linguístico (Scherre, 1998). Ferindo o princípio da economia (DuBois, 1985; Haiman, 1983) e o princípio da quantidade (Givón, 1991), que preveem uma tendência funcional de não codificação explícita do que é previsível, mas apenas do que é necessário, são inúmeros os exemplos nas línguas naturais da repetição no discurso de codificações semelhantes, o chamado paralelismo linguístico. A concordância de número do português brasileiro é um deles:

“... em algumas circunstâncias, tende-se a repetir variantes explícitas de plural - codificando mais o que é mais previsível - e tende-se a repetir variantes zero de plural - codificando menos o que é menos previsível." (Scherre, 1998:31)

Ao testar a influência do paralelismo oracional sobre a presença da variante explícita de plural nos predicativos e particípios passivos, Naro \& Scherre (1991) encontraram um efeito significativo das marcas do verbo: a marca de plural no verbo favorece a marca de plural nos predicativos (as coisas tãa caras), ao passo que a marca zero no verbo favorece a marca zero (as coisa tá $\operatorname{cara} \varnothing)$.

Na busca do entendimento da atuação do paralelismo linguístico, Scherre (1998:51) aponta para a necessidade de investigar "a direcionalidade da repetição: se da esquerda para a direita ou se bidirecional". No caso do emprego variável de INFflex, analisado nesta tese, é bastante pertinente a questão da direcionalidade dos efeitos da repetição: além de possíveis efeitos de marcas de plural à esquerda do infinitivo, é importante investigar se também marcas plurais à direita do infinitivo têm efeito na escolha por INFflex. Os resultados da análise realizada nesta tese, apresentados no capítulo 4, lançam luz sobre essa questão. 


\subsection{Síntese}

Após apresentar as questões que norteiam o presente estudo e a proposta de como se pretende respondê-las, discutiu-se, neste capítulo, a perspectiva teórica que se adota. Procurou-se demostrar que este estudo aborda a variação no emprego de INFflex em PB com base na visão de que tanto a frequência de uso quanto significados sociais são cruciais em processos de propagação de variantes linguísticas, tais como a expansão de INFflex para novos contextos sintáticos. No âmbito da Sociolinguística Cognitiva, este presente estudo é conduzido à luz (i) da proposta sociocognitiva de Croft (2000) em relação a processos de variação e mudança linguística, (ii) dos resultados a que Boyland (2001) chegou em seu estudo sobre a hipercorreção no inglês, (iii) da proposta de Hock e Joseph acerca de efeitos da frequente correção explícita, e (iv) e dos consistentes achados de inúmeros estudos variacionistas sobre a concordância verbal em PB (Brandão \& Vieira 2012; Mendes \& Oushiro 2015; Naro \& Scherre 2013; Oushiro 2015; Rubio \& Gonçalves 2012, inter alia). 


\section{3 \\ Materiais e Métodos}

\subsection{Construindo o Corpus Pós_USP}

Partindo do conceito de que um corpus - conjunto de textos coletados criteriosamente para análises linguísticas - é uma amostra que se pretende investigar com o intuito de fazer generalizações acerca da população alvo, ${ }^{1} \mathrm{o}$ corpus deve ser representativo e balanceado para que tais generalizações sejam válidas (Biber, 1993; Gries, 2009; McEnery et al., 2005; Woods et al., 1986). A representatividade de uma amostra está ligada à presença das diferentes partes que compõem a população, enquanto o balanceamento depende de que tais partes apareçam na amostra na mesma proporção em que ocorrem na população. ${ }^{2}$ Embora não existam "critérios objetivos para a determinação da representatividade" (Berber Sardinha, 2000 : 5), "corpora representativos e balanceados são um ideal teórico que compiladores de corpus sempre têm em mente" (Gries, 2009 : 8). ${ }^{3}$ Neste estudo, cuja população alvo é o conjunto total de teses produzidas por alunos de pós-graduação da USP, contemplou-se a questão da representatividade do corpus adotando-se os seguinte critérios:

- seriam coletadas teses produzidas entre 1995 e 2014, portanto, no

1 Uma população alvo é o conjunto total de valores que se pretende investigar a partir de uma amostra (Woods et al., 1986:57). No contexto linguístico, uma população pode ser, por exemplo, uma língua ou uma variedade linguística.

2 No que diz respeito à extensão ideal de um corpus, utilizam-se diferentes abordagens na Linguística de Corpus: Biber (1993) se fundamenta em teorias estatísticas, Leech (1991 apud Berber Sardinha 2000) entende que um corpus não deve ter menos que 1 milhão de palavras, enquanto Sinclair (1996 apud Berber Sardinha 2000) acredita que quanto maior puder ser o corpus, melhor.

3 Original: “... representative and balanced corpora are a theoretical ideal corpus compilers constantly bear in mind..." 
intervalo de 20 anos;

- estariam representadas as 3 grandes áreas do conhecimento: Humanas, Exatas e Biológicas;

- seriam selecionadas 3 unidades de cada grande área, para um total de 9 unidades da USP;

- a seleção das unidades seria feita com base na disponibilidade, no Banco de Teses da USP, de textos produzidos nos anos 90: seriam selecionadas as que apresentassem maior número de teses disponíveis;

- seriam selecionadas até 10 teses por unidade por ano; quando possível, 5 teses de homens e 5 de mulheres.

Com base nesses critérios, desenhou-se, portanto, um corpus representativo do conjunto total de teses produzidas na USP, denominado Corpus Pós_Usp.

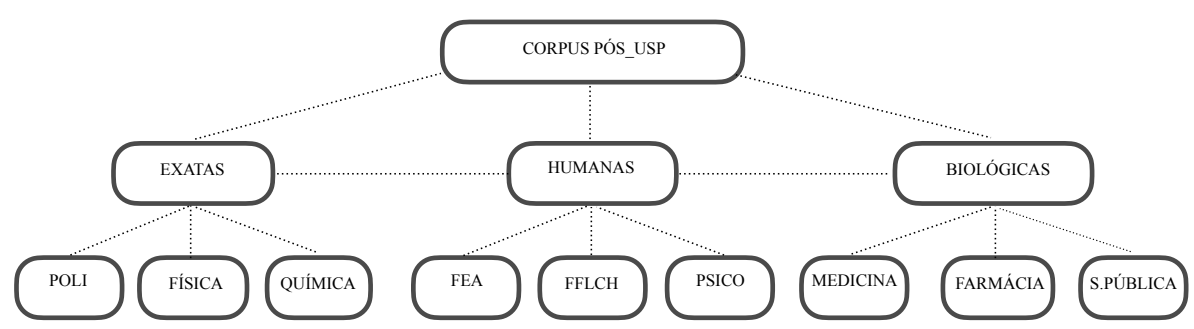

Figura 3.1 Arquitetura do Corpus Pós_USP

\section{Coleta e preparação dos textos}

Definida a estrutura do corpus, realizou-se a seleção das teses diretamente do Banco de Teses da USP. Por meio da ferramenta de busca avançada disponibilizada na plataforma, foi feito, manualmente, o download das teses por unidade e por ano, seguindo-se a ordem de apresentação das mesmas nas páginas de cada ano. 
Aproximadamente 1500 teses em .pdf foram baixadas e todas foram convertidas para .txt, ${ }^{4}$ formato exigido por softwares utilizados para a extração automática dos dados, tais como o R (R Team, 2017), Antconc (Anthony, 2014), entre outros. Excluídos os arquivos que apresentaram erro no processo de conversão para txt devido à qualidade dos .pdfs, os 1346 arquivos cuja conversão foi bem-sucedida foram, então, nomeados de acordo com o padrão "unidade_ano_sexo_número", que se vê na figura 3.2.

\begin{tabular}{|l|l|l}
\hline Pastas & Pastas & Documentos \\
\hline Corpus Pós_USP & Farma & quim00M1.txt \\
\hline Corpus_Pós_Usp_por área & Fea & quim00M2.txt \\
FFLCH & Fisica & quim01F1.txt \\
Med & quim01F2.txt \\
Poli & quim01M1.txt \\
Psico & quim01M2.txt \\
\hline Química & quim01M3.txt \\
\hline Spubl & quim01M4.txt \\
& & quim02F1.txt \\
& & quim02F2.txt \\
& & quim02F3.txt \\
& & quim02M1.txt \\
& & quim02M2.txt \\
& & quim02M3.txt \\
\end{tabular}

Figura 3.2 Exemplo da codificação dos arquivos que compõem o Corpus Pós_USP

Seguindo esse padrão, "quim00F1" significa "química, ano 2000, mulher 1", o código "quim00F2" significa "química, ano 2000, mulher 2", "quim01M1" significa "química, ano 2001, homem 1", e assim por diante. A nomeação dos arquivos, portanto, foi feita de modo a explicitar informações essenciais para a posterior codificação das ocorrências extraídas de cada arquivo de acordo com a área, unidade, ano e sexo.

Concluídas as etapas de arquitetura e construção da amostra de teses, o produto final a que se chegou foi um corpus de aproximadamente 90 milhões de palavras, composto por 1346 arquivos de teses, distribuídas de acordo com os anos, áreas e unidades, como mostra a tabela 3.1.

4 A conversão de .pdf para .txt foi feita por meio do software iSkysoft PDF editor PRO. 
Tabela 3.1 Corpus Pós_USP: Número de teses por áreas, unidades e anos

\begin{tabular}{|c|c|c|c|c|c|c|c|c|c|c|c|c|c|c|c|c|c|c|c|c|c|c|}
\hline \multirow[b]{2}{*}{ ÁREA } & \multirow[b]{2}{*}{ UNIDADE } & \multicolumn{21}{|c|}{ ANOS } \\
\hline & & 1995 & 1996 & 1997 & 1998 & 1999 & 2000 & 2001 & 2002 & 2003 & 2004 & 2005 & 2006 & 2007 & 2008 & 2009 & 2010 & 2011 & 2012 & 2013 & 2014 & Totais \\
\hline \multirow{3}{*}{ Exatas } & poli & 2 & 0 & 10 & 8 & 10 & 10 & 10 & 10 & 10 & 10 & 10 & 10 & 10 & 10 & 10 & 10 & 10 & 10 & 10 & 10 & 180 \\
\hline & quim & 0 & 0 & 2 & 0 & 2 & 2 & 6 & 7 & 5 & 3 & 9 & 9 & 10 & 10 & 8 & 10 & 10 & 10 & 10 & 10 & 123 \\
\hline & fisica & 1 & 0 & 0 & 1 & 3 & 4 & 5 & 1 & 1 & 6 & 6 & 7 & 8 & 9 & 6 & 8 & 10 & 7 & 8 & 5 & 96 \\
\hline \multirow{3}{*}{ Humanas } & psico & 1 & 3 & 5 & 5 & 5 & 10 & 10 & 8 & 10 & 10 & 10 & 10 & 10 & 10 & 10 & 10 & 10 & 8 & 10 & 10 & 165 \\
\hline & fea & 4 & 7 & 0 & 6 & 6 & 10 & 10 & 10 & 10 & 10 & 10 & 10 & 10 & 10 & 10 & 10 & 10 & 10 & 10 & 10 & 173 \\
\hline & fflch & 1 & 1 & 7 & 4 & 10 & 10 & 10 & 10 & 10 & 10 & 10 & 10 & 10 & 10 & 10 & 10 & 10 & 10 & 10 & 10 & 173 \\
\hline & farma & 0 & 0 & 2 & 1 & 4 & 0 & 3 & 1 & 4 & 4 & 7 & 8 & 8 & 10 & 10 & 9 & 10 & 10 & 10 & 10 & 111 \\
\hline \multirow[t]{2}{*}{ Biológicas } & med & 3 & 2 & 2 & 5 & 9 & 5 & 10 & 10 & 10 & 10 & 10 & 10 & 10 & 9 & 10 & 10 & 10 & 10 & 10 & 10 & 165 \\
\hline & spubl & 1 & 1 & 1 & 3 & 5 & 10 & 10 & 10 & 10 & 10 & 10 & 10 & 10 & 10 & 10 & 10 & 10 & 10 & 10 & 9 & 160 \\
\hline Totais & & 13 & 14 & 29 & 33 & 54 & 61 & 74 & 67 & 70 & 73 & 82 & 84 & 86 & 88 & 84 & 87 & 90 & 85 & 88 & 84 & 1346 \\
\hline
\end{tabular}

Como se pode ver na tabela 3.1, é menor a quantidade de teses nos primeiros anos, o que significa que o corpus não está balanceado como idealmente deveria estar. Embora tenham sido selecionadas as unidades com o maior número de teses da década de 90, em certos anos há menos de 10 teses disponibilizadas online. Além da baixa disponibilidade, a qualidade de alguns dos arquivos mais antigos é baixa, o que impossibilita sua conversão para o formato .txt. No entanto, a despeito de limitações relacionadas à amostragem, tais como essa, Woods et al. (1986:56) sugerem, com foco no avanço do conhecimento, que se aceitem os resultados de cada estudo como se a amostragem tivesse sido feita seguindo o ideal teórico e que, então, se investigue a possibilidade de tais resultados terem sido distorcidos pelo modo como foi construída a amostra. Tal abordagem, que, segundo os autores, deve vir acompanhada de uma descrição cuidadosa de como foram obtidos os dados, é adotada neste estudo.

\subsection{Etiquetagem do corpus}

Em se tratando de um corpus sem qualquer tipo de anotação gramatical, a extração das ocorrências de INFflex poderia ser feita de modo automático buscando-se todas as ocorrências de palavras terminadas em -rmos ou -rem, desinências número-pessoais referentes a 1PP e 3PP. Naturalmente, de uma busca como essa, seriam obtidas ocorrências que não são INFflex, como os verbos ocorrem e preferem, e substantivos como enfermos ou termos - este último, inclusive, formalmente idêntico à forma flexionada do infinitivo do 
verbo ter na $1 \mathrm{PP}$-, que precisariam, então, ser excluídos. No entanto, não interessam apenas as ocorrências de INFflex; seguindo o Princípio da Contabilidade $^{5}$ (Labov, 1969 : 738), devem ser quantificadas todas as ocorrências de INF $\varnothing$ nas quais o INFflex poderia ter ocorrido. Aplicando-se a mesma lógica das buscas por -rmos ou -rem no caso do INFflex, seria, então, necessário fazer a busca por palavras terminadas em - $r$ para extrair as ocorrências de INF $\varnothing$. Além das ocorrências de INFØ (1PP e 3PP) que interessam, o resultado de uma busca como essa incluiria não apenas substantivos como ar, mas todas as ocorrências de INF $\varnothing$ de 1PS e 3PS, casos que não interessam à análise e que precisariam ser excluídos. Dada a extensão do corpus - 90 milhões de palavras -, seria exorbitante o número de dados que precisariam ser excluídos, tornando, portanto, inviável o procedimento de extração das ocorrências de INFflex e INF $\varnothing$ de 1 PP e 3PP por meio de buscas por palavras terminadas em $-r$.

Para tornar a extração dos dados mais eficiente, decidiu-se etiquetar o corpus, processo através do qual acrescentam-se etiquetas com informações gramaticais a cada palavra dos textos. No entanto, etiquetadores comuns não diferenciam INF $\varnothing$ de 1PS e 3PS dos INF $\varnothing$ de 1PP e 3PP, ou seja, a etiqueta é a mesma para todos os infinitivos não flexionados, independente da pessoa verbal. Assim, ainda precisaria ser feita outra limpeza de modo a excluir as numerosas ocorrências de INFØ de singular.

Um etiquetador mais robusto, capaz de resolver a questão da etiquetagem de INF $\varnothing$ de 1 PP e 3PP e desenvolvido especialmente para o português é o PALAVRAS (Bick, 2000, 2014). ${ }^{6}$ Baseado na gramática restritiva, metodologia de análise sintática de linguagem natural lançada por Karlsson (1995 apud Bick 2000), o PALAVRAS funciona por meio de regras dependentes de contexto, escritas por linguistas, compiladas em uma gramática que atribui etiquetas de diferentes níveis linguísticos a cada palavra dos textos.

No que diz respeito à etiquetagem de infinitivos, o resultado padrão do PALAVRAS seria a atribuição de etiquetas de 1PS, 2PS, 3PS, 1PP, 2PP

5 Principle of Accountability: "that any variable form (a member of a set of alternative ways 'of saying the same thing') should be reported with the proportion of cases in which the form did occur in the relevant envinronment, compared to the total number of cases in which it might have occurred."

6 http://visl.sdu.dk/constraint_grammar.html 
e $3 \mathrm{PP}^{7}$ às ocorrências de infinitivo com flexão ou sujeito explícito à sua esquerda, de modo que infinitivos sem flexão ficam subespecificados, recebendo simplesmente a etiqueta INF (sem especificação de pessoa verbal). No entanto, adicionando-se ao PALAVRAS uma mini-gramática com regras que buscam um sujeito ou uma flexão de verbo finito no contexto à esquerda dos infinitivos, o etiquetador é capaz de atribuir etiquetas número-pessoais às ocorrências de INF $\varnothing$ de 1PP e 3PP, diferenciando-as das ocorrências de INF $\varnothing$ de 1PS e 3PS. Sendo assim, a etiquetagem sintática do Corpus Pós_USP por meio dessa versão adaptada do PALAVRAS viabilizou a extração das ocorrências de infinitivos referentes a sujeitos plurais por meio das etiquetas referentes a $1 \mathrm{PP}$ e a $3 \mathrm{PP} .^{8}$

Um exemplo de um infinitivo que não teria recebido a etiqueta de 1PP na versão padrão do PALAVRAS, por não estar flexionado e nem ter um sujeito explícito à sua esquerda, pode ser visto em 1.

(1) Porém, não são conhecidos probióticos capazes de se instalar no ecossistema digestivo... (farma03F2)

Em sua versão adaptada, no entanto, o PALAVRAS buscou um sujeito ou verbo finito à esquerda do infinitivo instalar e atribuiu a ele a etiqueta "V_INF_3P". ${ }^{9}$ como se vê na figura 3.3.

Porém_ADV_@ADVL $>$,_PU_@PU não_ADV_@ADVL $>$ são_<aux > V_PR_3P_IND_VFIN_@FS-STA conhecidos_<mV $>$ V_PCP_M_P_@ICL-AUX probióticos_ADJ_M_P_@ $<$ SUBJ capazes_ADJ_M/F_P_@N $<$ de_PRP_@A $<<$ se_PERS_M/F_3S_ACC_@ACC $>$ instalar_<mv $>$ V_INF_3P_@ICL-P $<$ em_PRP_@ $<$ OA o_DET_M_S_@ $>$ N ecossistema_N_M_S_@P $<$

Figura 3.3 Texto do exemplo 1 etiquetado pelo PALAVRAS

Embora o processo de etiquetagem dos infinitivos por meio do PALAVRAS represente um enorme ganho metodológico para este estudo, ele, naturalmente, não está livre de erros. Com a aplicação das regras que buscavam à esquerda

7 Respectivamente, primeira pessoa do singular, segunda pessoa do singular, terceira pessoa do singular, primeira pessoa do plural, segunda pessoa do plural, terceira pessoa do plural

8 Tanto para a adição da mini-gramática quanto para a etiquetagem em si, esta tese contou com a colaboração acadêmica de Eckhard Bick, a quem eu agradeço por ter realizado o processo de etiquetagem do corpus em seu próprio servidor.

9 As etiquetas do PALAVRAS para a primeira e terceira pessoa do plural são 1P e 3P, e não 1PP e 3PP, como se adotou nesta tese. 
candidatos a sujeito do infinitivo, algumas formas de singular receberam a etiqueta de plural, como o infinitivo ser do exemplo 2:

(2) $\quad \ldots$ empresas com mais de 1000 empregados destinam menos de $1 \%$ de o faturamento bruto para ser investido em P\&D. (fea00F2)

Nesse caso, o infinitivo ser recebeu a etiqueta "V_INF_3P" quando, na verdade, se trata de um INF $\varnothing$ referente a 3PS (terceira pessoa do singular). A ocorrência de casos como esse exigiu, uma vez extraídas automaticamente todas as ocorrências de "V_INF_3P" e "V_INF_1P", uma revisão qualitativa muito cuidadosa dos dados. A seção 3.4 se dedica a esse processo.

\subsection{Extração dos dados}

Realizou-se a extração de todas as ocorrências das etiquetas "V_INF_3P" e "V_INF_1P" por meio do software Antconc (Anthony, 2014) ${ }^{10}$ No total, extraíram-se 285.182 dados, acompanhados de seus contextos precedentes e seguintes, que foram salvos em duas planilhas - uma com as ocorrências de infinitivos referentes à $1 \mathrm{PP}$ e outra com as ocorrências de infinitivos referentes à $3 \mathrm{PP}$.

Tabela 3.2 Total de infinitivos extraídos do corpus

\begin{tabular}{lrrr}
\hline & \multicolumn{1}{c}{$1 \mathrm{PP}$} & \multicolumn{1}{c}{$3 \mathrm{PP}$} & Totais \\
\hline INFflex & 7.537 & 38.907 & 46.444 \\
INFØ & 41.147 & 197.591 & 238.738 \\
\hline Totais & 48.684 & 236.498 & 285.182 \\
\hline
\end{tabular}

Do total de 285.182 dados extraídos do corpus, extraíram-se, então, as ocorrências relativas aos três contextos sintáticos opcionais "originais" (Bos-

\footnotetext{
10 Inicialmente as extrações foram feitas no software R, utilizando a função exact.matches de Stefan Th. Gries. No entanto, o processo com o software $\mathrm{R}$ omitiu milhares de ocorrências, muito provavelmente em função do formato dos textos que constituem o corpus - textos convertidos de .pdfs. Optou-se, assim, pela extração com o Antconc, que apresentou resultados mais satisfatórios.
} 
saglia, 2013a:27) investigados neste estudo: orações adverbiais - quando o sujeito do infinitivo é correferente ao sujeito da oração principal (3 e 4) -, complementos de adjetivos ( 5 e 6 ) e complementos de nomes $(7$ e 8$) .{ }^{11}$

(3) Brown e Eisenhardt (1998, p. 3) vão nessa mesma direção ao colocarem que a abordagem tradicional da estratégia... (fea05M1)

(4) Estas cadeias se organizam para formar o grão de amido, uma macroestrutura altamente condensada que preenche o amiloplasto...(farma01M1)

(5) ... e eram mais susceptíveis a acreditarem que outros controlavam os eventos em suas vidas... (spubl06M3)

(6) Quando informações relevantes sobre uma instituição são difíceis de ser obtidas, a escola pode ser excluída... (fea09F1)

(7) Supõe-se que os homens não encontrados apresentem menor probabilidade de terem tido algum episódio de acidente vascular cerebral. (med10F3)

(8) Dessa forma essas tendências, esses afetos, que foram construídos nas relações, perdem a possibilidade de circularem quando se cristalizam nos sujeitos como características e atributos individuais. (psico96F1)

No caso das orações adverbiais, extraíram-se todas as ocorrências de INFflex e INF $\varnothing$ precedidos pelas preposições/locuções prepositivas investigadas por Vanderschueren (2013), Vanderschueren \& Diependaele (2013) e Vanderschueren \& de Cuypere (2014) - para, por, sem, ao, antes de, depois de - $\mathrm{e}$ também pela preposição após, chegando-se a um total de 41.625 dados. ${ }^{12}$ As ocorrências de INFflex e INF $\varnothing$ como complementos de adjetivos e substantivos, por sua vez, foram extraídas das planilhas gerais a partir das etiquetas N (nome), ADJ (adjetivo) e PRP (preposição), totalizando, respectivamente, 6391 e 13.428 dados. Juntas, as ocorrências relativas aos três contextos sintáticos totalizam 61.444 dados, o que equivale a aproximadamente $20 \%$ do total de dados extraídos corpus.

\footnotetext{
11 A segunda etapa de extração foi feita diretamente nas planilhas.

12 A decisão de trabalhar com tais preposições foi tomada não apenas pensando-se na comparabilidade dos resultados com os achados desses autores, mas também porque são essas as preposições que mais frequentemente introduzem orações adverbiais.
} 
Tabela 3.3 Total de dados por contexto sintático antes da revisão

\begin{tabular}{lr}
\hline & \multicolumn{1}{c}{ INF } \\
\hline Adverbiais & 41.625 \\
Complementos de adjetivo & 6391 \\
Complementos de nomes & 13.428 \\
\hline Total & 61.444 \\
\hline
\end{tabular}

Entre os contextos sintáticos que não são objeto da análise quantitativa realizada neste estudo estão os infinitivos que formam locuções verbais, nos quais a ocorrência de INFflex é considerada um uso hipercorrigido. Apenas as ocorrências de INFØ $3 \mathrm{PP}$ como complemento de verbo auxiliares, tais como os verbos poder e dever, como nos exemplos 9 e 10, totalizam 76.202 dados.

... os cristais podem formar aglomerados de esferulitos com tamanhos de centenas de micrômetros...(farma01F2)

(10) Dois aspectos devem ser ressaltados nestas informações. (fflch03M2)

Uma vez que a ocorrência de INFØ nesses casos é quase categórica na língua escrita padrão, tal como demonstra Canever (2012), que encontrou $0.3 \%$ de INFflex em 353 ocorrências de infinitivos que servem de complemento a verbos auxiliares modais, esses dados não interessam ao presente estudo, pois a opcionalidade de INFflex, ainda que possível, não foi frequentemente verificada. No entanto, na medida em que sim interessa a esta tese verificar a ocorrência de usos hipercorretos no corpus, fez-se um levantamento das ocorrências de INFflex nesses casos, que também integram os estímulos auditivos no estudo de percepção (capítulo 5). ${ }^{13}$

\subsection{Revisão qualitativa dos dados}

Antes de proceder à análise quantitativa, as 61.444 ocorrências de infinitivo referentes a cada um dos três contextos sintáticos, salvas em subconjuntos

\footnotetext{
13 O levantamento revelou 8 ocorrências de INFflex como complementos de verbos não auxiliares: 3 ocorrências com 3PP e 5 ocorrências com 1PP.
} 
separados, precisaram ser qualitativamente revistas. Essa revisão foi feita tendo-se em mente os possíveis erros no processo automático de etiquetagem do corpus (seção 3.2 acima) e a necessidade de verificar se todas as ocorrências de INFflex ou INFØ extraídas correspondiam, de fato, a dados de interesse para o estudo da variável em foco.

\section{Orações adverbiais}

No que diz respeito às orações adverbiais, a fim de manter no conjunto de dados apenas aqueles em que de fato INFflex e INFØ são formas opcionais (3 e 4), foi necessário realizar uma revisão das 41.625 ocorrências de INFflex e INFØ. Excluíram-se, por exemplo, casos cuja leitura de impessoalidade é possível, senão a mais imediata, com em:

(12) Foram realizados dois ensaios para confirmar o comportamento de os queijos cremosos nas condições planejadas inicialmente. (farma05F2)

(13) Quais são os principais planos para atingir estes objetivos? (fea10M2)

(14) Existem vários métodos para estimar o LOD, todos os quais dependem da análise de branco de amostras... (farma12M5)

Além de excluir 3880 ocorrências de INF $\varnothing$ com verbos ou leituras impessoais (exemplos 11-14), nesses mesmos casos excluíram-se também as ocorrências de INFflex $1 \mathrm{PP}$ que àqueles se equiparam.

(15) Portanto, há um amplo espaço para discutirmos o investimento em educação... (fea03F1)

(16) Para apresentarmos essas premissas filosóficas, é necessário retomar o alicerce filosófico de a agricultura convencional... (fflch03M5)

Levando-se em conta o Princípio da Contabilidade (Labov, 1969), como não é possível contabilizar todos os casos quais nos quais INFflex poderia ter ocorrido em construções com verbos impessoais como as dos exemplos 15 e 16, descartaram-se tanto as ocorrências de INFflex quanto as de INFØ relativas 
a esse caso.

Excluíram-se, também, ocorrências nas quais havia mais de uma interpretação possível para o sujeito do infinitivo, como em:

Guha, Druin e Fails (2008) propõem um modelo para incluir crianças com deficiência no design. (poli14F4)

Em 17, o sujeito de incluir pode ser "Guha, Druin e Fails", que, "para incluir crianças com deficiência no design, propõem um modelo", leitura na qual INFflex 3PP poderia ocorrer; e há, ainda, a leitura de que "tais autores propõem um modelo que visa a incluir crianças com deficiência no design", leitura na qual INFflex 3PP não poderia ocorrer. Ocorrências como essas (que totalizam 1.696) foram excluídas do conjunto de dados.

Por outro lado, devido à insuficiência de elementos no contexto precedente e subsequente de certos exemplos (tais como foram extraídos e organizados na planilha) a partir dos quais se pudesse identificar o sujeito do infinitivo, excluíram-se ocorrências desse tipo:

....a rede, combinando-as com a topologia descrita pelo sistema, para indicar o local mais provável de o defeito. (poli01M2)

e os indutores internos Ls e Ld, sem considerar os pads, é $0,41 \mathrm{~mm} \ldots$ (poli12F1)

em diferentes pHs $(2.0$ - 9.0), para investigar os efeitos de concentração... (fisica08M2)

Essa questão da insuficiência de contextos - identificada em 2.495 dados poderia, em princípio, ser resolvida a partir da volta a cada tese em busca de mais contexto, tarefa que levaria um tempo incomensurável. No entanto, embora o número de tais casos seja alto para uma tarefa manual, trata-se de uma fração pequena em relação ao conjunto de 61.444 dados com que se trabalhou na revisão dos dados (Tabela 3.3). Além disso, considerando-se as proporções de casos analisados e excluídos, optou-se por não voltar às teses, uma vez que parte desses 2.495 dados não seria de casos em que, de fato, o sujeito é plural. Para 19, por exemplo, a volta à tese (poli12F1) revelou 
o seguinte contexto precedente (em negrito): A área ocupada pelo core do $\boldsymbol{F C}-\boldsymbol{L N} \boldsymbol{A}$ e os indutores internos Ls e Ld, sem considerar os pads, é $0,41 \mathrm{~mm} \ldots$ (poli12F1)". Nesse caso, a adição de mais contexto mostrou que esse é um dado que não interessa a essa tese e que seria excluído de qualquer modo.

Por fim, excluíram-se ocorrências que não são de orações adverbiais, tais como infinitivos que servem de complemento a verbos não auxiliares (21 e 22), nos quais este estudo não se detém, além de ocorrências de substantivos terminados em -rmos (23) e infinitivos com sujeitos singulares (24).

(21) Assim, optamos por utilizar apenas o primeiro fator, que analisa o desempenho financeiro geral das empresas. (fea10F4)

(22) Os canais anastomosados caracterizam-se por apresentar multiplicidade de canais, pequenos e rasos, que se subdividem... (fflch13F4)

(23) Nos termos desse ofício, lê-se o seguinte. (fflch97F1)

(24) Ressaltamos neste último exemplo a falta de limite ético da profissional ao enunciar um julgamento de valor moral sobre a vida sexual da paciente... (med10F4)

Em 23, termos é um substantivo e vem precedido da preposição em contraída com o artigo definido o (nos). O etiquetador, porém, atribuiu ao substantivo termos a etiqueta de INF-1PP e a nos a etiqueta de pronome oblíquo de 1PP. Em 24, enunciar recebeu a etiqueta INF-1PP, embora seu sujeito seja "a profissional". Entre dados complementos de verbos não-auxiliares, substantivos terminados em - mos e infinitivos com sujeitos singulares foram excluídos 16.509 dados.

\section{Complementos de adjetivos}

No caso dos complementos de adjetivos, foi necessário excluir da respectiva planilha de dados os adjetivos empregados com sentido passivo, cujos complementos não poderiam ser flexionados, como em:

(25) Abacaxis bons de comer não se encontram no Brasil em estado selvagem, 
mas são fartamente cultivados em sítios... (fflch02F3)

(26) Mesmo que as medidas fossem fáceis de realizar, essas são informações que não têm quase nenhuma utilidade na prática. (fisica11M1)

Fazem parte do envelope de variação, no entanto, casos em que esses mesmos adjetivos têm como complemento infinitivos na voz passiva, de modo que casos como 27 e 28, evidentemente, tiveram que permanecer na planilha:

As duas primeiras razões são relativamente fáceis de serem medidas. $(\operatorname{med} 01 \mathrm{M} 5)$

... os dados referentes ao salário foram difíceis de ser analisados porque muitas pessoas deixaram de declará-lo. (psico08F2)

\section{Complementos de substantivos}

Em relação aos complementos de substantivos, de modo que permanecessem na planilha os substantivos mais frequentemente empregados com complementos de INF 1PP e INF 3PP, decidiu-se ficar com aqueles que tiveram, pelo menos, 50 ocorrências. Verificou-se, ainda, por meio das etiquetas gramaticais, se havia, no contexto adjacente à esquerda do infinitivo, verbos finitos que possibilitassem a identificação da correferencialidade entre os sujeitos do verbo principal e o do infinitivo, como em:

(29) Os executivos têm alguma possibilidade de alocar vendas e uma... (fea02M5)

(30) Os indivíduos com pontuação acima desse limiar têm alta possibilidade de apresentarem morbidade psiquiátrica." (med05M2)

Um exemplo dos dados de complemento de substantivo que foram excluídos é do seguinte tipo:

... conforme já mencionamos, muitas vezes apresenta a mesma dificuldade de relacionar um elemento tridimensional a sua representação bidimensional. (fflch13M5)

Embora o infinitivo relacionar tenha recebido a etiqueta de $1 \mathrm{PP}$ no processo 
de etiquetagem, na busca por um verbo finito com flexão de 1PP à esquerda, encontra-se, mais próximo ao substantivo, o verbo apresenta, verbo finito de 3PS cujo sujeito é o verdadeiro correferente àquele de relacionar (e não o sujeito de mencionamos). Foram excluídos todos o casos como esses, bem como infinitivos que não continham verbos finitos plurais à esquerda dos infinitivos em foco.

Finalizada a cuidadosa revisão dos dados nos três subconjuntos, chegou-se a um total de 24.945 dados, como mostra a Tabela (3.4).

Tabela 3.4 Total de dados por contexto sintático depois da revisão

\begin{tabular}{lr}
\hline & \multicolumn{1}{c}{ INF } \\
\hline Adverbiais & 17.045 \\
Complementos de adjetivo & 4.205 \\
Complementos de nomes & 3.695 \\
\hline Total & 24.945 \\
\hline
\end{tabular}

\subsection{Codificação dos dados e variáveis independentes}

Reagrupados em uma única planilha, os dados foram, então, codificados de acordo com as variáveis independentes, resumidas no Quadro 3.1.

\begin{tabular}{|c|c|c|c|}
\hline \multirow{2}{*}{ VARIÁVEIS INDEPENDENTES } & \multicolumn{3}{|c|}{ Contexto Sintático } \\
\hline & Oração adverbial & Complemento de adjetivo & Complemento de substantivo \\
\hline \multirow{3}{*}{ Posição } & anteposta & - & - \\
\hline & intercalada & - & - \\
\hline & posposta & - & - \\
\hline Pessoa Verbal & \multicolumn{3}{|c|}{$1 \mathrm{PP} 3 \mathrm{PP}$} \\
\hline Verbo & \multicolumn{3}{|c|}{ verbo ser outros verbos } \\
\hline Ano & \multicolumn{3}{|c|}{ de 1995 a 2014} \\
\hline Arquivo & \multicolumn{3}{|c|}{ Nome do arquivo } \\
\hline Autor & \multicolumn{3}{|c|}{ Nome do autor } \\
\hline Sexo & \multicolumn{3}{|c|}{$\mathrm{F} \quad \mathrm{M}$} \\
\hline Área do conhecimento & \multicolumn{3}{|c|}{ Humanas, Biológicas, e Exatas } \\
\hline Unidade & \multicolumn{3}{|c|}{ FFLCH, FEA, Psico, Farmácia, Medicina, Saúde Pública, Politécnica, Física, e Química } \\
\hline
\end{tabular}

Quadro 3.1 Variáveis independentes 
Como se vê no Quadro 3.1, as orações adverbiais foram codificadas de acordo com a sua posição em relação à oração principal. Ilustram orações adverbiais codificadas como preposta (32), intercalada (33) e posposta (34) os seguintes exemplos:

(32) Antes de sermos religiosas, devemos ser boas cristãs, cumprindo fielmente os mandamentos. (fflch00F4)

(33) Estas variáveis, por serem de períodos distintos, décadas de 90 e 2000, foram modeladas inicialmente ... (poli06M3 )

... não entramos na cooperativa para ser populares e sabíamos que era uma medida muito antipática. (fea00M5)

A respeito da variável Verbo, convém destacar que se optou por ela e não pela variável Voz devido ao uso frequente do verbo ser com predicativos plurais. Das 2240 ocorrências com o verbo ser com INF 1PP e INF 3PP, 1040 são empregados com particípios (em construções de voz passiva) (35 e 36) e 1200 são empregados com predicativos plurais (37 e 38):

(35) Esses arquivos mantém uma ordem para ser executados que depende de a modelagem de o banco de dados. (poli01M2)

(36) Antes de serem encaminhados às tipografias, os relatórios dos presidentes eram confeccionados como discursos político-administrativos autógrafos. (fflch10M5)

(37) Alguns alimentos, como os petiscos, bolachas e biscoitos, precisam ter uma menor Aw para ser crocantes. (poli00F1)

(38) Por serem universais, tais princípios devem ser aplicáveis em quaisquer situações com que o contabilista (fea05M2)

Sendo assim, para abarcar tanto os casos do ser com particípios quanto aqueles com predicativos plurais, decidiu-se codificar os verbos entre ser e outros verbos.

O quadro 3.1 mostra, ainda, que, além da variável Arquivo, foi incluída a variável Autor, uma vez que 68 autores tiveram dois textos incluídos na 
amostra - sua dissertação de mestrado e sua tese de doutorado.

\subsection{Síntese}

Apresentadas as questões relativas à construção do Corpus Pós_Usp, formado por 1346 teses produzidas por alunos de diferentes áreas de conhecimento entre 1995 e 2014, este capítulo discutiu a extração e revisão qualitativa dos dados extraídos. Descreveu-se, portanto, como foram levantados os dados de infinitivo que permitem testar as hipóteses deste estudo, dentre as quais destaca-se a hipótese de que o emprego de INFflex em contextos opcionais na escrita padrão estaria aumentando.

No capítulo seguinte, apresentam-se os resultados das análises descritivas, feitas com o conjunto total de dados, e também das análises multivariadas, feitas com cada um dos três contextos sintáticos. 


\section{4 \\ INFflex ao longo de 20 anos na redação acadêmica}

$p=$ Neste capítulo, apresentam-se os resultados das análises dos 24.945 dados de infinitivos nos três contextos opcionais "originais" (Bossaglia, 2013a:27): orações adverbiais reduzidas, complementos de adjetivos e complementos de substantivos.

Considerando-se que várias ocorrências foram extraídas de uma mesma tese - tendo sido produzidas, portanto, por um mesmo autor -, enquanto outras foram produzidas por um mesmo autor em dois momentos diferentes (na dissertação de mestrado e na tese de doutorado), existe uma estrutura de dependência entre as observações da amostra que deve ser devidamente levada em conta. ${ }^{1}$ Para contabilizar a correlação existente entre os dados de um mesmo indivíduo, utilizaram-se modelos de regressão logística de efeitos mistos (Fitzmaurice et al., 2011). Nesses modelos, além dos efeitos fixos - as variáveis independentes -, inseriram-se Autor, Arquivo e Item $^{2}$ como efeitos aleatórios, controlando-se, assim, os possíveis efeitos dessas variáveis. O software utilizado na análises foi o R - versão 3.2.4 (R Team, 2017).

Na seção 4.1.1, análises descritivas oferecem um panorama da distribuição dos dados de acordo com as variáveis independentes do estudo: primeira-

\footnotetext{
1 A questão da (in)dependência dos dados deve ser considerada na seleção dos métodos mais apropriados para a análise, uma vez que inúmeros testes estatísticos têm como uma de suas assunções a independência dos dados, tais como o teste de qui-quadrado, por exemplo (Gries, 2013).

2 Essa variável diz respeito ao item que precede o infinitivo: preposições, locuções prepositivas, substantivos e adjetivos.
} 
mente, apresentam-se análises de todos os dados em conjunto e, em seguida, apresentam-se separadamente as análises daqueles de cada um dos três contextos sintáticos. Na seção 4.2, apresentam-se os resultados das análises multivariadas.

\subsection{Distribuição dos dados}

\subsubsection{Dados gerais}

Com base nos achados de Canever (2012), que trabalhou com 180 teses produzidas por alunos da área de Letras da FFLCH-USP e encontrou uma taxa de $73 \%$ de INFflex $(\mathrm{N}=687)$ nos três contextos sintáticos analisados neste estudo, esperava-se que INFflex seria mais frequente que INF $\varnothing$, mesmo levando-se em conta a inclusão da variável Ano, não analisada por Canever. No presente trabalho, que analisou com um número consideravelmente maior de 1346 teses, do total de 24.945 dados, 32,32\% são ocorrências de INFflex:

Tabela 4.1 Distribuição geral dos dados

\begin{tabular}{lll}
\hline & $\mathrm{N}$ & $\%$ \\
\hline INFflex & 8061 & 32,32 \\
INFØ & 16884 & 67,68 \\
\hline
\end{tabular}

Considerando-se cada contexto separadamente, Canever (2012) encontrou uma taxa de $75 \%$ de INFflex em orações adverbiais $(\mathrm{N}=525), 53,5 \%$ de INFflex em complementos de adjetivos $(\mathrm{N}=101)$ e $94,5 \%$ de INFflex em complementos de nomes ( $\mathrm{N}=54$ ). No presente estudo, a proporção de INFflex nos três contextos sintáticos foi consideravelmente menor, sendo 40,16\% nas adverbiais, $22,88 \%$ nos complementos de adjetivos e $6,85 \%$ nos complementos de nomes, como mostra a tabela 4.1.1. 
Tabela 4.2 Distribuição de INFflex por contexto sintático

\begin{tabular}{lllll}
\hline & \multicolumn{2}{c}{ INFflex } & \multicolumn{2}{c}{ Totais } \\
Contexto Sintático & \multicolumn{1}{c}{ N } & \multicolumn{1}{c}{$\%$} & \multicolumn{1}{c}{ N } & \multicolumn{1}{c}{$\%$} \\
\hline adverbiais & 6846 & 40,16 & 17045 & 68,33 \\
compl_adjetivos & 962 & 22,88 & 4205 & 16,86 \\
compl_nomes & 253 & 6,85 & 3695 & 14,81 \\
\hline
\end{tabular}

O gráfico 4.1.1 apresenta as proporções de INFflex em cada contexto sintático, cujas diferenças se mostraram significativas $(p<0,001)$. O valor de $p$ foi calculado por meio de uma Regressão Logística de efeitos mistos univariada.

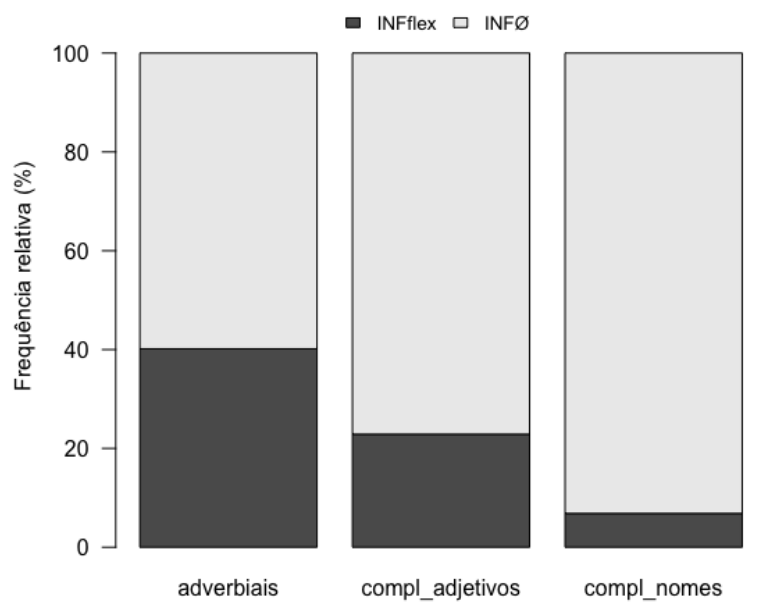

Figura 4.1 Distribuição de INFflex por contexto sintático

Entre as unidades da USP, houve diferença significativa nas proporções de INFflex $(p<0,001)$, sendo Física e Politécnica as unidades que apresentaram as maiores taxas de INFflex, respectivamente 43,39\% e 39,71\%. FEA e FFLCH, por sua vez, apresentaram as menores, respectivamente $29,79 \%$ e 30,57\%. As proporções de INFflex de acordo com as unidades da USP podem ser visualizadas na Figura 4.1.1. 


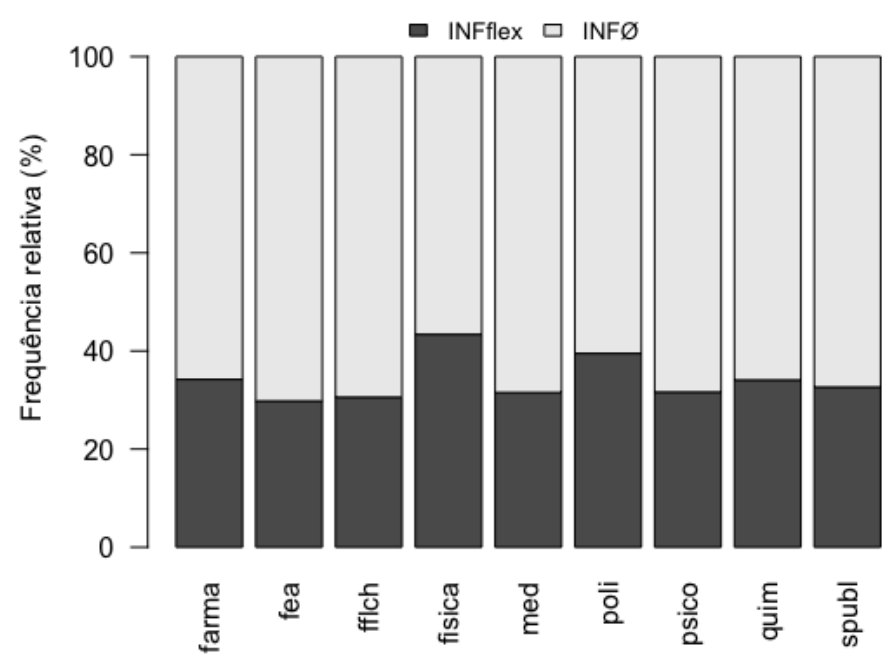

Figura 4.2 Distribuição de INFflex por faculdade

Considerando-se as áreas do conhecimento, aquela que apresentou maior proporção de INFflex foi a área de Exatas $(39,17 \%, p<0,001)$, enquanto, no que diz respeito ao sexo dos autores das teses, apresentaram maior proporção de INFflex teses produzidas por homens (33,90\%). Como se vê na Figura 4.3, a diferença entre homens e mulheres, que apresentaram 30,95\% de INFflex, foi relativamente pequena, porém significativa $(p=0,018) .^{3}$
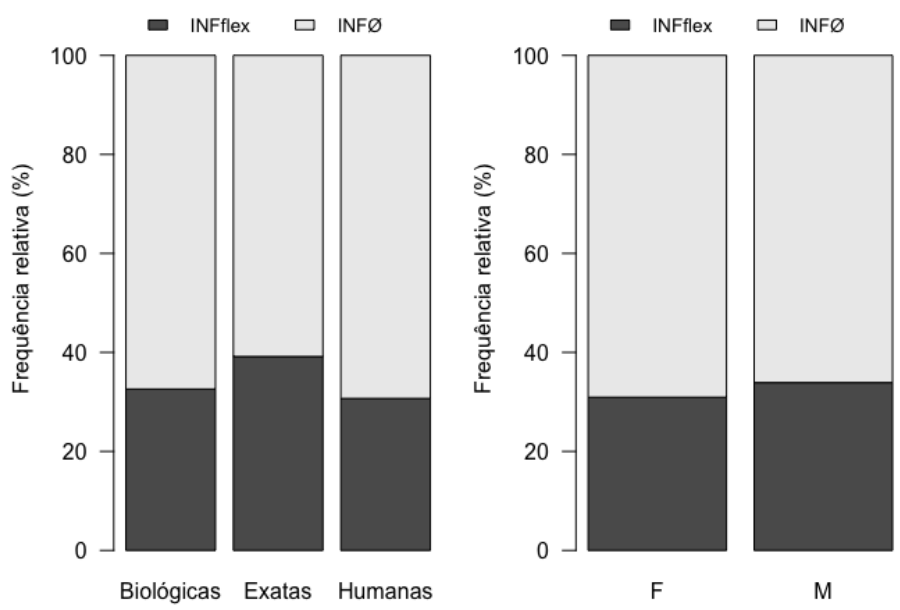

Figura 4.3 Distribuição de INFflex por área e por sexo do autor

3 A tabela completa com a análise descritiva do efeito individual das variáveis Unidade, Área do conhecimento, Sexo do Autor, Pessoa Verbal, Contexto Sintático e Verbo pode ser vista no Anexo A. 
A análise descritiva da proporção de INFflex de acordo com a variável Ano, indica que, ao contrário do que se esperava, o emprego de INFflex não parece estar aumentando com o tempo. Além da estabilidade que se nota entre os anos de 1995 a 2011, a Figura 4.4 mostra uma leve queda.

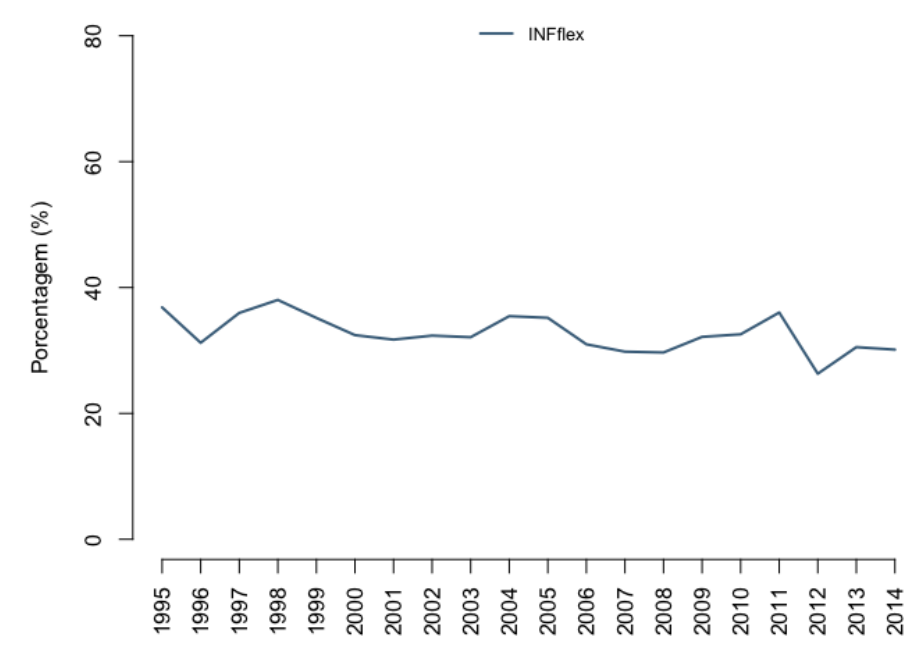

Figura 4.4 Distribuição de INFflex ao longo de 20 anos

Em relação à influência da variável Pessoa Verbal ao longo do tempo, apenas em 1997 e em 1999 houve diferença significativa nas proporções de INFflex com 1PP e 3PP. Nesses anos, a proporção de INFflex foi significativamente maior na 3PP. Apenas em 2011 a proporção de INFflex foi mais alta com a $1 \mathrm{PP}$, porém essa diferença não é significativa $(p=0.863)$. Diferentemente do que se esperava, esses resultados indicam que 1PP não favorece o emprego de INFflex. $^{4}$

4 A tabela completa da análise descritiva da variável Pessoa Verbal ao longo do tempo está no Anexo A. 


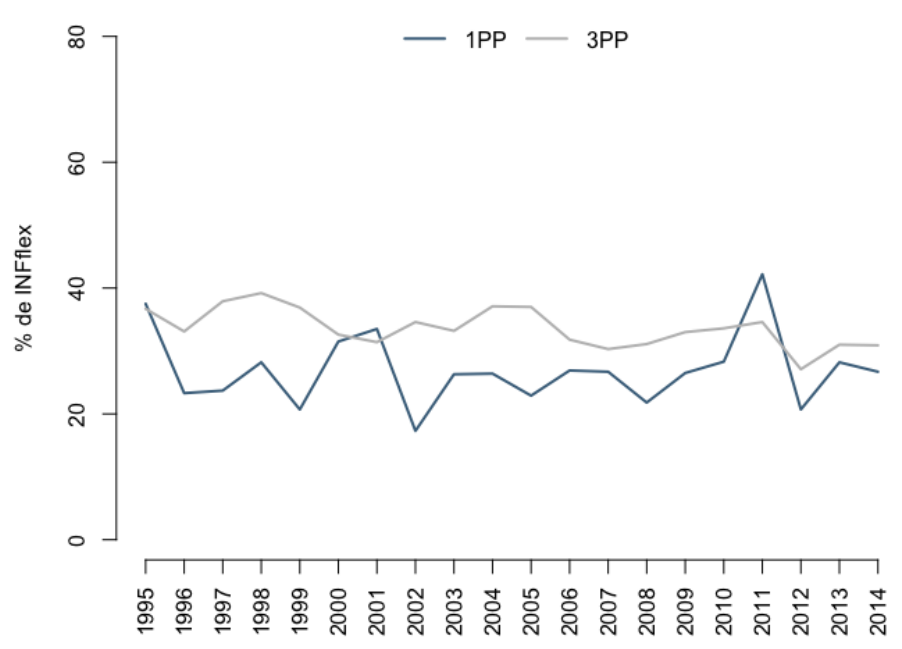

Figura 4.5 Distribuição de INFflex por pessoa verbal ao longo de 20 anos

Tal como se esperava, a proporção de INFflex com o verbo ser foi expressivamente superior à proporção de INFflex com os outros verbos ${ }^{5}$ como se vê na Figura 4.6. Essa diferença entre os verbos, significativa em todos os anos, é interpretada neste estudo como um efeito do paralelismo linguístico (ver seção 13), sendo o emprego de INFflex favorecido pelas marcas de plural no particípios e predicativos à direita do verbo ser. Discute-se essa questão na seção 4.3 .

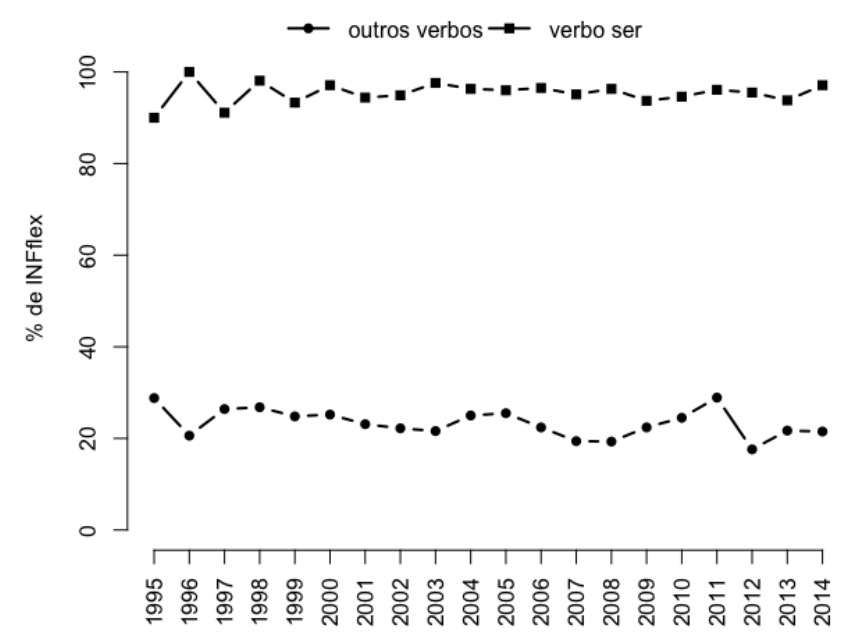

Figura 4.6 Distribuição de INFflex por tipo de verbo ao longo de 20 anos

\footnotetext{
5 A tabela com a análise descritiva da variável verbo ao longo dos anos está no Anexo A.
} 
Também se mostrou significativa em todos os anos a variável Contexto Sintático: a proporção de INFflex é maior nas adverbiais e menor nos complementos de nomes. ${ }^{6}$

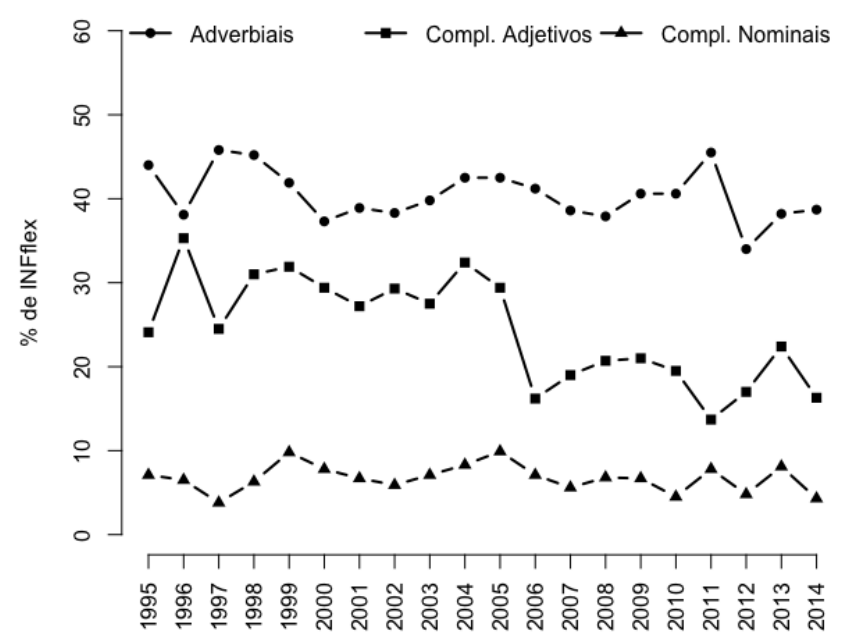

Figura 4.7 Distribuição de INFflex por contexto sintático ao longo de 20 anos

Embora as proporções de INFflex em complementos de nomes tenha se mantido relativamente estável ao longo dos anos, nota-se, na Figura 4.7, uma leve queda na proporção de INFflex em orações adverbiais a partir de 2012, e uma queda mais acentuada na proporção de INFflex em complementos de adjetivo a partir de 2006 .

Nas próximas seções, apresentam-se análises descritivas dos dados de cada contexto sintático separadamente.

\subsubsection{Orações adverbiais}

A análise descritiva dos dados de infinitivo em orações adverbiais revelou que INFflex é menos frequente com as preposições para e sem, ao passo que, com antes de, ao, após, depois de e por, ${ }^{7}$ a proporção de INFflex ficou acima de 80\%. A Figura 4.8 mostra essa diferença.

\footnotetext{
6 Encontra-se a tabela com a análise descritiva da variável Contexto Sintático ao longo dos anos no anexo A.

7 Embora antes de e depois de sejam locuções prepositivas, nos gráficos todas são chamadas de "preposição".
} 


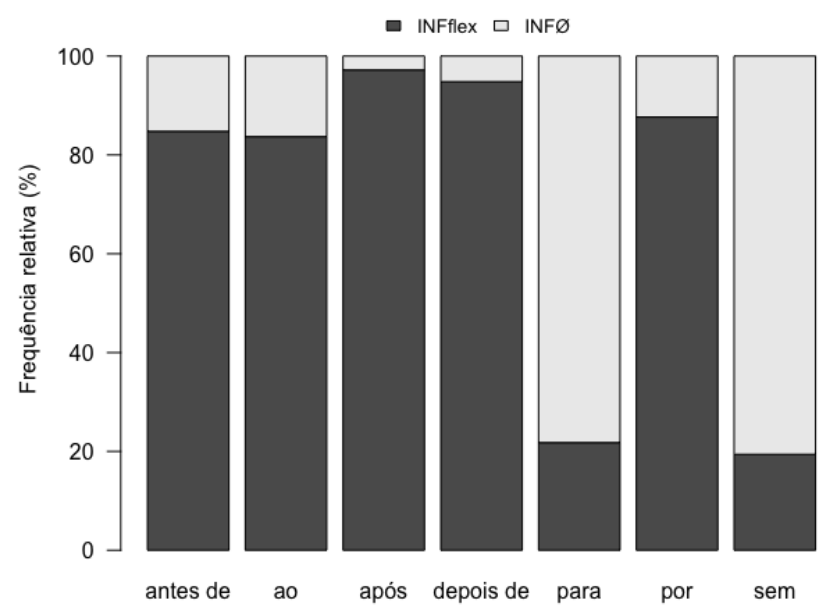

Figura 4.8 Distribuição de INFflex em orações adverbiais por preposição

Levando-se em conta a variável Ano, houve diferença significativa entre as proporções de INFflex de acordo com as preposições em todos os anos. Como mostra o gráfico 4.9, verificou-se que INFflex é menos frequente com as preposições com para e sem em todos os anos, enquanto o emprego mais frequente de INFflex com antes de, ao, após, depois de e por mostrou-se relativamente estável.

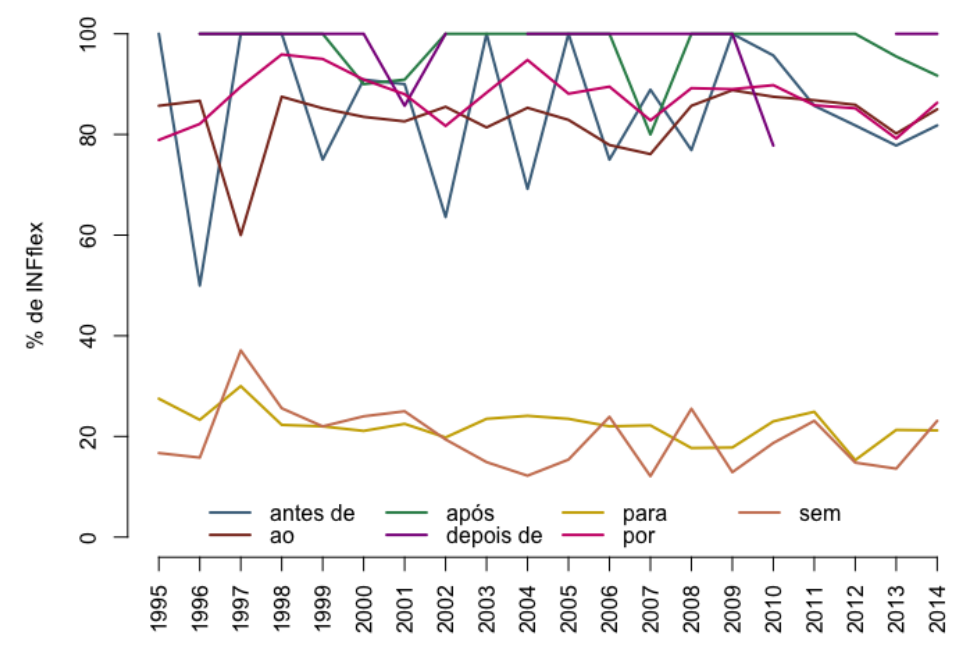

Figura 4.9 Distribuição de INFflex em orações adverbiais por preposição ao longo de 20 anos 
No que concerne à posição das orações adverbiais em relação à oração principal, a proporção de INFflex é maior posições quando elas se encontram antepostas ou intercaladas, como se vê no seguinte gráfico:

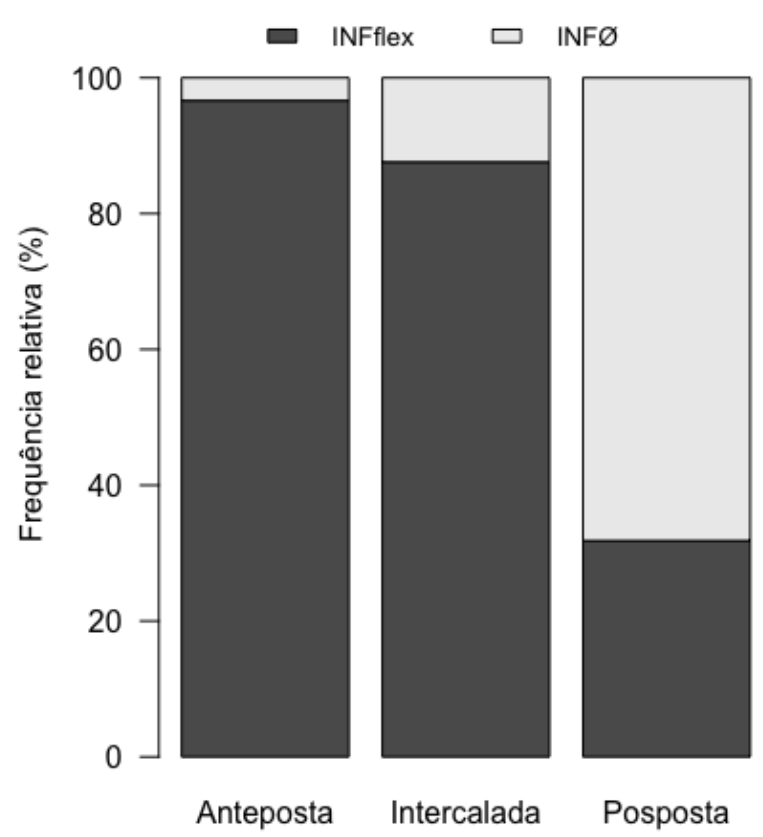

Figura 4.10 Distribuição de INFflex pela posição das orações adverbiais

A Figura 4.11, por sua vez, mostra o cruzamento das variáveis posição e preposição, que revelou que, quando a oração adverbial é posposta à oração principal, são maiores as diferenças nas proporções de INFflex de acordo com as preposições. ${ }^{8}$

8 A tabela com a análise descritiva do cruzamento da variável preposição e posição está no anexo A. 

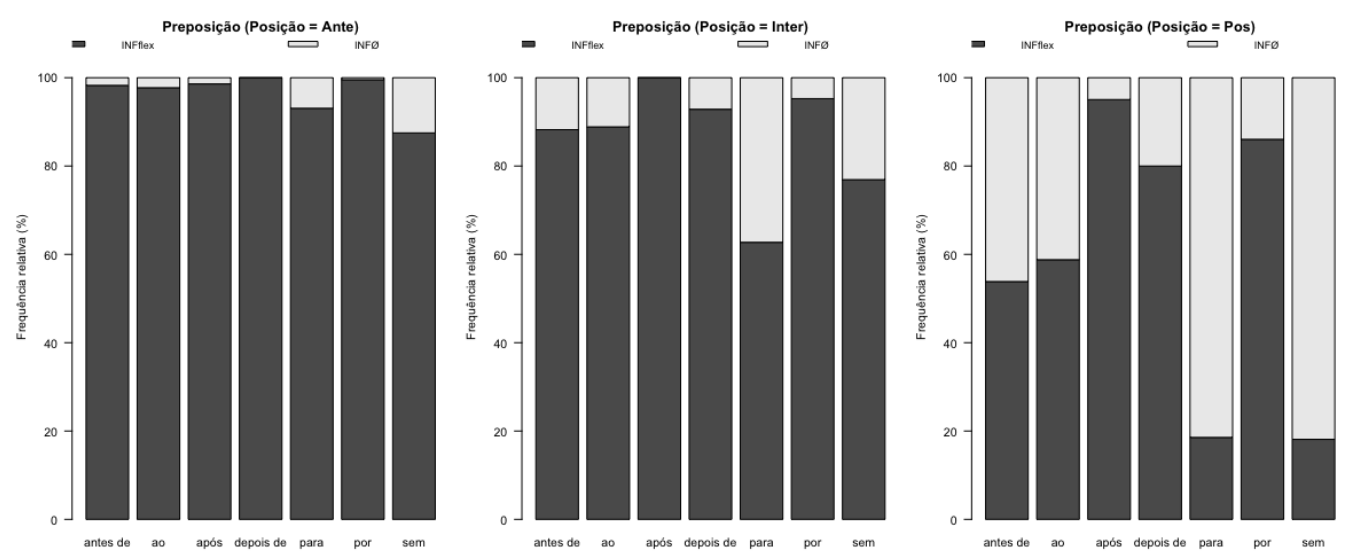

Figura 4.11 Distribuição de INFflex de acordo com a posição das orações adverbiais e com as preposições, respectivamente: antes de, ao, após, depois de, para, por e sem

Embora o emprego de INFflex seja menos frequente com as preposições para e sem em orações adverbiais pospostas à oração principal (18,60\% e 18,10\%), as proporções de INFflex com tais preposições são mais altas quando as orações são antepostas e intercaladas: quando antepostas, a proporção de INFflex com para é $93,10 \%$ e com sem 87,50\%, e quando intercaladas $62,70 \%$ e 76,90\%, respectivamente.

Ainda em relação à variável Posição, testou-se sua interação com pessoa verbal. Os resultados dessa análise são apresentados na Tabela 4.3.

Tabela 4.3 Análise descritiva do cruzamento das variáveis pessoa verbal e posição das adverbiais

\begin{tabular}{|c|c|c|c|c|c|c|}
\hline \multirow{2}{*}{\multicolumn{2}{|c|}{ Variáveis }} & \multicolumn{2}{|c|}{ INFflex } & \multicolumn{2}{|c|}{ INFØ } & \multirow{2}{*}{$p^{1}$} \\
\hline & & \multirow{3}{*}{$\begin{array}{c}\mathbf{N} \\
457 \\
809\end{array}$} & \multirow{3}{*}{$\begin{array}{c}\% \\
95,20 \% \\
97,50 \%\end{array}$} & \multirow{3}{*}{$\begin{array}{l}\mathbf{N} \\
23 \\
21\end{array}$} & \multirow{3}{*}{$\begin{array}{c}\% \\
4,80 \% \\
2,50 \%\end{array}$} & \\
\hline Posicão - antenosta & $1 \mathrm{PP}$ & & & & & 0 \\
\hline 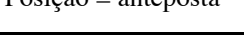 & 3PP & & & & & 0 \\
\hline \multirow{2}{*}{ Posição = intercalada } & $1 \mathrm{PP}$ & 3 & $42,90 \%$ & 4 & $57,10 \%$ & \multirow{2}{*}{0,036} \\
\hline & 3PP & 894 & $87,90 \%$ & 123 & $12,10 \%$ & \\
\hline \multirow{2}{*}{ Posição = posposta } & $1 \mathrm{PP}$ & 527 & $20,30 \%$ & 2072 & $79,70 \%$ & \multirow{2}{*}{0,573} \\
\hline & 3PP & 4156 & $34,30 \%$ & 7956 & $65,70 \%$ & \\
\hline \multirow{3}{*}{$1 \mathrm{PP}$} & Posição = anteposta & 457 & $95,20 \%$ & 23 & $4,80 \%$ & \multirow{3}{*}{0} \\
\hline & Posição = intercalada & 3 & $42,90 \%$ & 4 & $57,10 \%$ & \\
\hline & Posição = posposta & 527 & $20,30 \%$ & 2072 & $79,70 \%$ & \\
\hline \multirow{3}{*}{$3 \mathrm{PP}$} & Posição = anteposta & 809 & $97,50 \%$ & 21 & $2,50 \%$ & \multirow{3}{*}{0} \\
\hline & Posição = intercalada & 894 & $87,90 \%$ & 123 & $12,10 \%$ & \\
\hline & Posição = posposta & 4156 & $34,30 \%$ & 7956 & $65,70 \%$ & \\
\hline
\end{tabular}

${ }^{1}$ Regressão Logística com efeitos mistos bivariada

Nas três posições - anteposta, intercalada e posposta -, a proporção de INFflex é maior com 3PP, mas a diferença é significativa apenas nas posições 
anteposta e intercalada. Esses mesmos resultados são apresentados na Figura 4.12 .
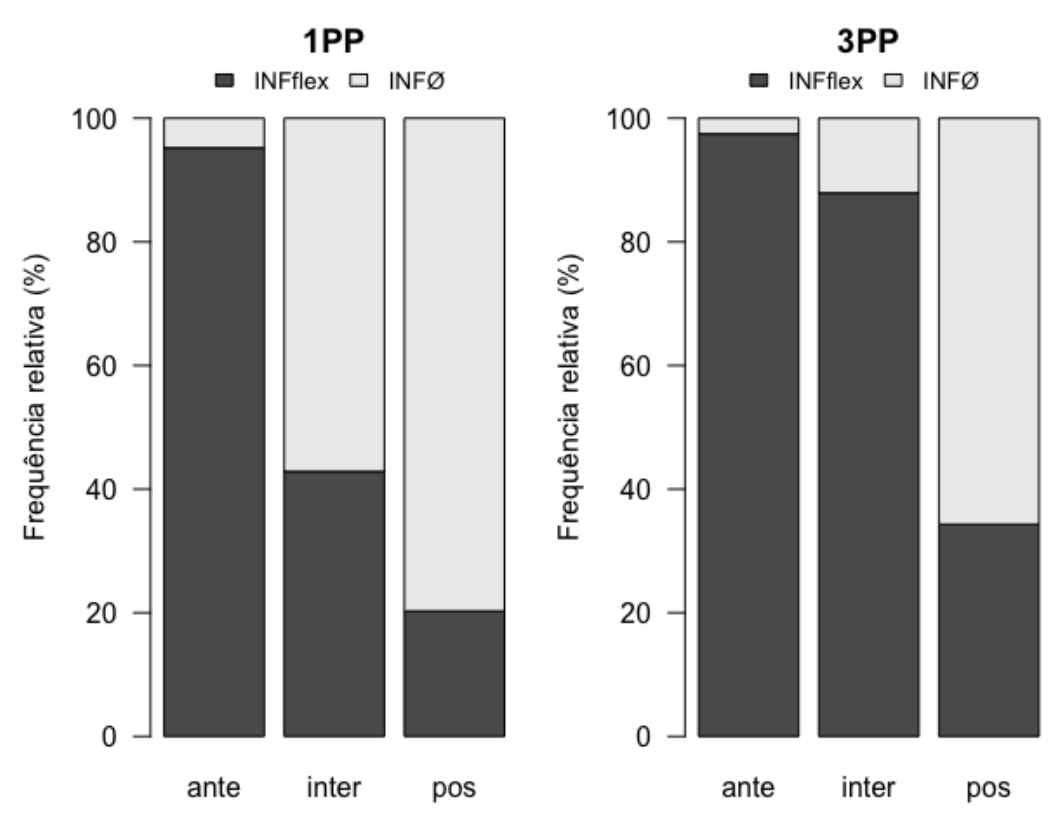

Figura 4.12 Distribuição de INFflex pela posição da adverbial e pela pessoa verbal

Com as duas pessoas verbais, portanto, a proporção de INFflex é maior quando a oração adverbial está anteposta à oração principal, como nos exemplos:

(1) Para obtermos um contrafactual melhor do grupo de=tratamento, usaremos o método de Propensity Score Matching. (fea14F1)

(2) Porém, ao estarem economizando nos custos, os mesmos pressionavam a fábrica para que a mesma fornecesse... (poli03M1)

(3) Antes de falarmos da Auditoria de Sistema de Garantia da Qualidade, julgamos necessário compreender o contexto em que ela... (fea95M2)

(4) Para poderem fazer frente a tais restrições, os universitários necessitam frequentar cursos parciais, diurnos ou noturnos. (fea03F1)

(5) Para obter os aminoácidos, os pesquisadores reagiram os produtos de Sonogashira. (farma10F5) 
(6) Para calcular T a partir da equação 2.7, utilizamos a relação de Maxwell... (poli03M3)

É interessante notar que o emprego frequente de INFflex na posição anteposta é tratado como "regra" pelo gramático contemporâneo Nougué, como mencionado no capítulo 1. Ao afirmar que "é de regra flexionar o infinitivo quando empregado em oração adverbial anteposta à subordinante" (Nougué, 2015:574-575), o gramático se afasta daqueles que apresentam o emprego de INFflex como facultativo em orações adverbiais (Bechara 2009; Cunha \& Cintra 2013; Lima 2017 [1957]; Maurer Jr. 1968, inter alia), e aproxima-se dos autores das teses aqui analisadas.

Pode-se dizer que o arraigamento de INFflex em adverbiais antepostas no conhecimento linguístico de certos falantes é tão alto, que muitos já não veem opcionalidade nesses contextos.

\subsubsection{Complementos de adjetivos}

Analisando-se as ocorrências de infinitivo como complementos de adjetivos, verificou-se que, assim como nas adverbiais, a proporção de INFflex com o verbo ser foi expressivamente maior do que com os outros verbos $(p<0,001)$. Também verificou-se uma maior proporção de INFflex com 3PP $(p<0,001)$, conforme ilustra a Figura 4.13.
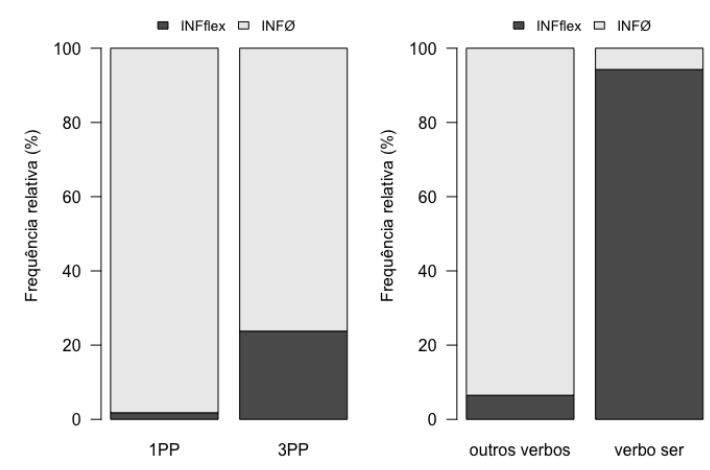

Figura 4.13 Distribuição de INFflex em complementos de adjetivos por pessoa verbal e por verbo

Observou-se, ainda, que essa diferença na proporção de INFflex com o 
verbo ser foi significativa em todos os anos $(\mathrm{p}<0,05)$.

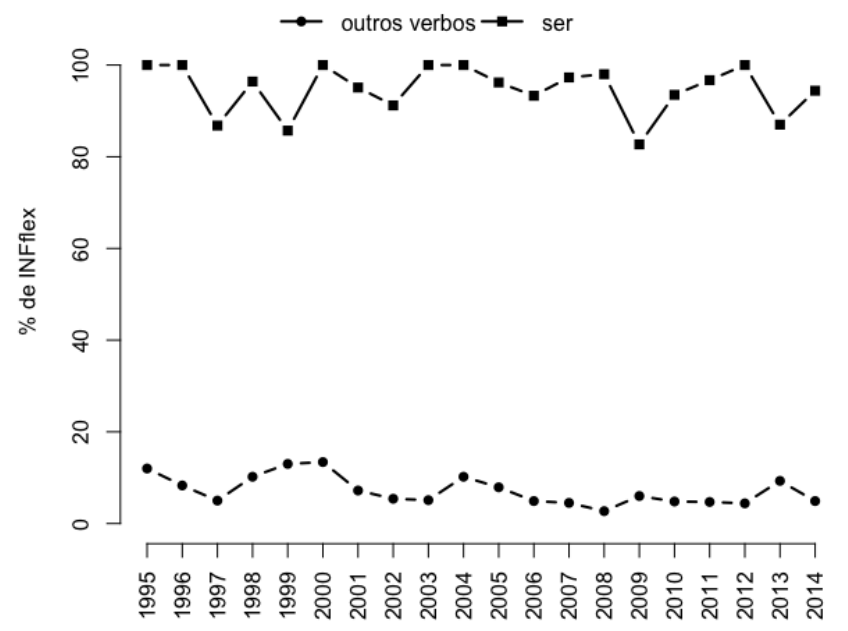

Figura 4.14 Distribuição de INFflex em complementos de adjetivos por verbo ao longo de 20 anos

(7) ... mésons leves são mais fáceis de serem produzidos do que bárions pesados (fisica07F1)

(8) Ou seja, apresenta-se a relação entre os elementos que compõem esse processo e que são importantes de serem considerados na medida em que se quer organizar o ensino... (psico11F4)

(9) Rochas Ornamentais e para Revestimento são aquelas capazes de ser extraídas de pedreiras sob a forma de blocos ou placa... spubl06F1

\subsubsection{Complementos de substantivos}

$\mathrm{Na}$ análise dos dados de infinitivos que servem de complementos a substantivos, verificou-se uma diferença significativa na proporção de INFflex em relação às unidades da USP $(p=0,009)$. Como mostra a Figura 4.15, a proporção de INFflex foi maior nas teses da Física, da Química e da Politécnica. 


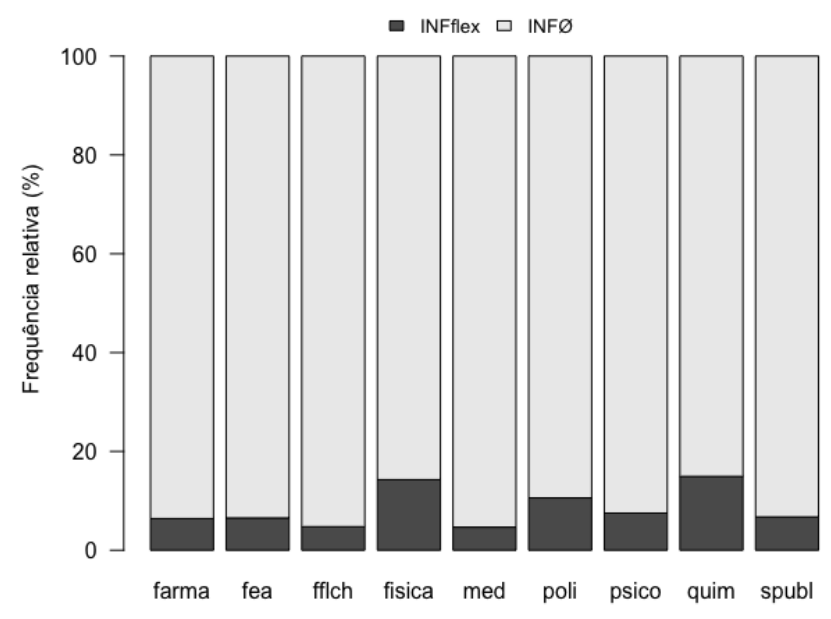

Figura 4.15 Distribuição de INFflex em complementos de substantivo por Unidade da USP.

A área de Exatas, portanto, apresentou maior proporção de INFflex em relação às outras áreas $(p=0,003)$ :

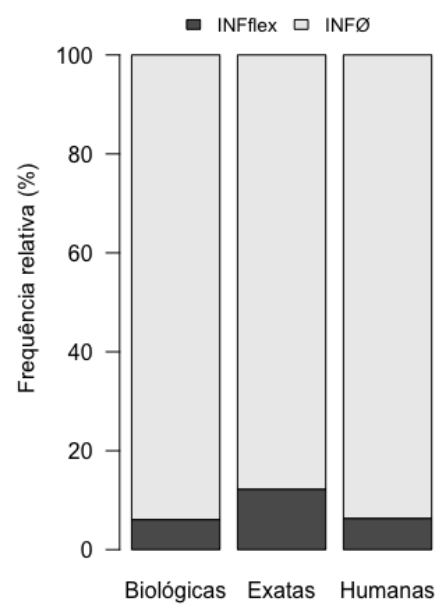

Figura 4.16 Distribuição de INFflex em complemento de substantivos por Área do conhecimento

Como se vê na Figura 4.17, em contextos de complementação de substantivos, a proporção de INFflex foi maior com o verbo ser $(p<0,001)$, assim como nas orações adverbiais e em complementos de adjetivos. Diferentemente das 
adverbiais e dos complementos de adjetivos, nos quais se verificou maior proporção de INFflex com a 3PP, em complementos de substantivos, a proporção de INFflex foi maior com a 1PP $(p<0,001)$ :
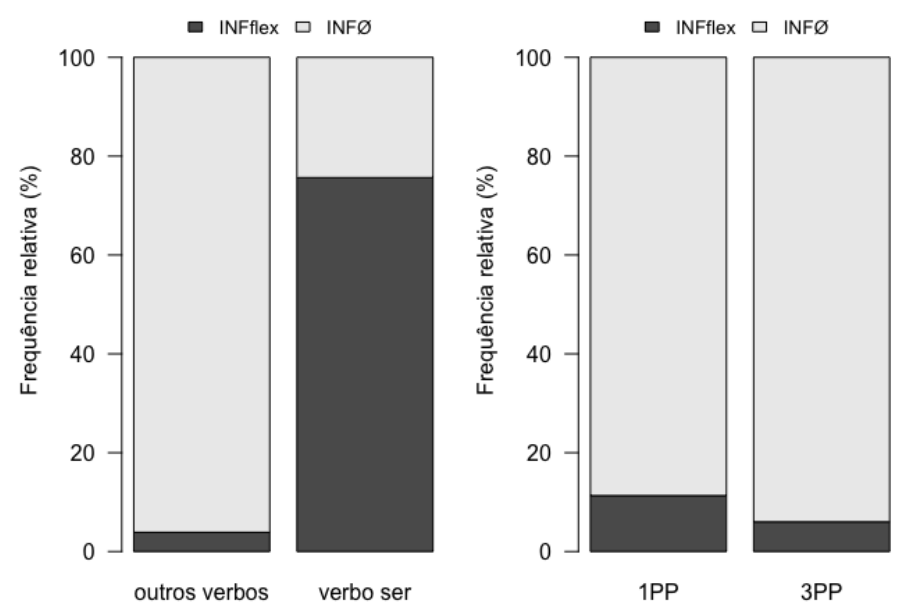

Figura 4.17 Distribuição de INFflex em complementos de substantivo por verbo e por pessoa verbal

(10) ...isso se tornava um argumento que fazia com que nós e as professoras vislumbrássemos a possibilidade de movimentarmos uma história escolar. (psico96F1)

(11) O mesmo amor que é capaz de fazer com que tenhamos vontade de sermos melhores... (med02M3)

(12) Nesse ponto, destacamos a necessidade de reavaliarmos a concepção de racionalidade envolvida no paradigma do capital humano... (fea03F1)

(13) ... revelava seus desejos, mesmo se estes fossem impossíveis de serem realizados. (med01M5) 


\subsection{Análises multivariadas}

Nesta seção, apresentam-se os resultados das análises que testaram, simultaneamente, os efeitos das variáveis independentes no emprego de INFflex.

Uma vez que há dados de um mesmo autor e, em 68 casos, mais de um texto por autor, para tratar devidamente essa correlação entre as dados, utilizaram-se modelos de regressão logística com efeitos mistos (Fitzmaurice, Laird e Ware 2012). Incluindo-se as variáveis Autor e Arquivo como efeitos aleatórios, é possível controlar os efeitos que tais variáveis podem ter nos resultados. Também foram incluídos como aleatórios os itens que precedem os infinitivos para controlar possíveis efeitos das diferentes preposições, locuções preposicionais, adjetivos e substantivos que precedem os infinitivos.

No que diz respeito às variáveis Unidade e Área do conhecimento, preferiuse não incluí-las simultaneamente, visto que ambas trazem, de certa forma, a mesma informação. Testados modelos que incluíram apenas uma dessas variáveis, optou-se por apresentar aqueles que incluíram a variável Área do conhecimento devido à facilidade de interpretação.

Aplicou-se o método Backward (Efroymson, 1960), procedimento que consiste em retirar, por etapas, as variáveis de maior valor de $p$ até que restem no modelo apenas as variáveis significativas. Para o método Backward, adotou-se um nível de significância de 5\%.

Apresentam-se, a seguir, os resultados das análises multivariadas realizadas com cada um dos três subgrupos de dados - adverbiais, complementos de adjetivos e complementos de nomes. A decisão de analisar os subgrupos um a um está relacionada ao fato de haver uma variável que se aplica apenas ao caso das orações adverbiais: a variável Posição. Em vez de excluí-la, possibilitando a análise dos três contextos sintáticos juntos, por tratar-se de uma variável relevante, optou-se por mantê-la e por ajustar modelos diferentes para os três grupos de dados. 


\subsubsection{Modelagem GLMM: ${ }^{9}$ Orações adverbiais}

A Tabela 4.4 apresenta o modelo logístico com efeitos mistos para INFflex antes (modelo inicial) e depois de aplicar o método Backward (modelo final). Os resultados são os seguintes:

Tabela 4.4 Modelo Logístico com efeitos mistos para INFflex em adverbiais

\begin{tabular}{lccc|ccc}
\hline \multirow{2}{*}{ Variáveis } & \multicolumn{3}{c|}{ Modelo inicial } & \multicolumn{3}{c}{ Modelo final } \\
\cline { 2 - 7 } & O.R. & I.C - 95\% & $\boldsymbol{p}$ & O.R. & I.C - 95\% & $\boldsymbol{p}$ \\
\hline Posição = posposta & - & - & - & - & - & - \\
Posição = intercalada & 10,12 & {$[7,77 ; 13,18]$} & 0 & 10,12 & {$[7,77 ; 13,19]$} & 0 \\
Posição = anteposta & 63,25 & {$[45,57 ; 87,78]$} & 0 & 63,25 & {$[45,58 ; 87,78]$} & 0 \\
\hline Verbo = outros verbo & - & - & - & - & - & - \\
Verbo = verbo ser & 132,29 & {$[100,86 ; 173,51]$} & 0 & 132,33 & {$[100,89 ; 173,56]$} & 0 \\
\hline Área = Biológicas & - & - & - & - & - & - \\
Área = Exatas & 1,23 & {$[0,98 ; 1,55]$} & 0,073 & 1,24 & {$[0,98 ; 1,55]$} & 0,068 \\
Área = Humanas & 1,26 & {$[1,05 ; 1,51]$} & 0,011 & 1,26 & {$[1,06 ; 1,51]$} & 0,011 \\
\hline Sexo = Feminino & - & - & - & & & \\
Sexo = Masculino & 1,02 & {$[0,88 ; 1,18]$} & 0,807 & & & \\
\hline Pessoa verbal = 1PP & - & - & - & & & \\
Pessoa verbal = 3PP & 0,81 & {$[0,71 ; 0,93]$} & 0,004 & 0,81 & {$[0,71 ; 0,93]$} & 0,003 \\
\hline Ano & 0,98 & {$[0,96 ; 0,99]$} & 0,002 & 0,98 & {$[0,96 ; 0,99]$} & 0,002 \\
\hline I Odds-Ratio (Razão de Chances) & \multicolumn{7}{c}{}
\end{tabular}

A chance de INFflex ocorrer em orações adverbiais intercaladas e antepostas à oração principal foi significativamente maior do que a de ocorrer em orações adverbiais pospostas, posição tomada como valor de referência. Em orações adverbiais intercaladas, a chance foi 10,12 [7,77; 13,19] vezes a chance de ocorrer em orações adverbiais pospostas. Em orações adverbiais antepostas, a chance de INFflex ocorrer foi ainda maior: $63,25[45,58 ; 87,78]$ vezes a chance de ocorrer em orações pospostas $(p<0.001)$.

Quanto às duas outras variáveis linguísticas - tipo de verbo e pessoa verbal -, o verbo ser apresentou uma chance de ser flexionado 132,33 [100,89; $173,56]$ vezes maior que os outros verbos $(p<0.001)$. Já a chance de INFflex ocorrer com a $3 \mathrm{PP}$ foi $0,81[0,71 ; 0,93]$ vezes a chance de ocorrer com a $1 \mathrm{PP}$ $(p=0,004)$. Considerando-se que o valor 1 diz respeito à chance de INFflex ocorrer com a variante de referência - $1 \mathrm{PP}$-, por estar abaixo de 1 , a chance de INFflex ocorrer com a 3PP é menor que a chance de INFflex ocorrer com

9 GLMM: Generalized linear mixed models. 
a 1PP. Em outras palavras, nas adverbiais, a chance de INFflex ocorrer é maior com $1 \mathrm{PP}$.

Quanto à variável Área do conhecimento, embora nas análises descritivas as proporções de INFflex tenham sido mais altas na área de Exatas, os resultados desses modelos demostram que, nas orações adverbiais, a chance de INF ocorrer na área de Humanas foi 1,26 [1,06; 1,51] vezes a chance de INFflex ocorrer em teses da área de Biológicas $(p=0.011)$. A chance de INFflex ocorrer em teses da área de Exatas foi $1,24[0,98 ; 1,55]$ vezes a chance de ocorrer na área de Biológicas, porém essa diferença não é significativa $(p=0,068)$. A variável Sexo do autor não se mostrou significativa e foi excluída do modelo final.

Por fim, levando-se em conta a variável Anos, houve diferença significativa $(p=0,002)$ : a cada ano, a chance de INFflex ocorrer foi $0,98[0,96 ; 0,99]$ vezes a chance do ano anterior. Esse resultado indica que, a cada ano, a chance de INFflex ocorrer diminuiu.

A Figura 4.18 apresenta o log das razões de chances (OR) para os efeitos aleatórios das preposições. 


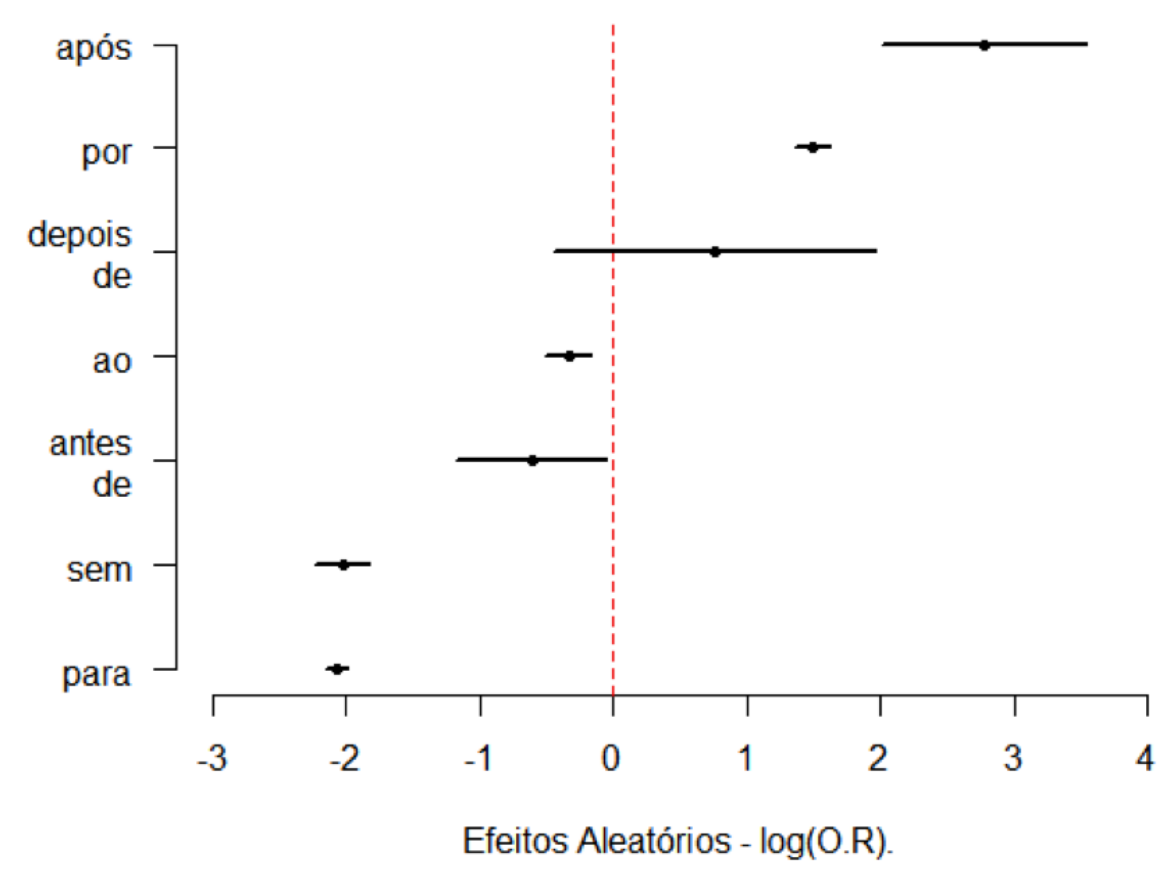

Figura 4.18 Efeitos aleatórios de Preposição (Adverbiais)

Enquanto a chance de INFflex ocorrer com as preposições após e por é maior que a média das preposições, há menores chances de INFflex ocorrer com as preposições ao, sem, para e a locução prepositiva antes de. A locução prepositiva depois de não apresentou diferença significativa na chance de INFflex, uma vez que o intervalo de confiança contém o valor 0 , ou seja, a chance de INFflex ocorrer com depois de é igual à chance média das preposições.

Ainda em relação ao subgrupo das adverbiais, ajustou-se um modelo logístico com efeitos mistos no qual se incluiu a interação entre as variáveis Posição e Pessoa Verbal. 
Tabela 4.5 Modelo Logístico com efeitos mistos para INFflex em adverbiais, considerando interação entre Posição e Pessoa Verbal

\begin{tabular}{|c|c|c|c|c|}
\hline \multicolumn{2}{|c|}{ Variáveis } & O.R. ${ }^{1}$ & I.C- $95 \%$ & $p$ \\
\hline \multirow{2}{*}{ Verbo } & Outros verbos & - & - & - \\
\hline & Verbo ser & 132,16 & {$[100,76 ; 173,34]$} & 0 \\
\hline \multirow{3}{*}{ Área } & Biológicas & - & - & - \\
\hline & Exatas & 1,23 & {$[0,98 ; 1,54]$} & 0,076 \\
\hline & Humanas & 1,27 & {$[1,06 ; 1,52]$} & 0,009 \\
\hline \multirow{2}{*}{ Posição = pos } & Pessoa verbal $=1 \mathrm{PP}$ & - & - & - \\
\hline & Pessoa verbal $=3 \mathrm{PP}$ & 0,83 & {$[0,72 ; 0,96]$} & 0,011 \\
\hline \multirow{2}{*}{ Posição = inter } & Pessoa verbal $=1 \mathrm{PP}$ & - & - & - \\
\hline & Pessoa verbal $=3 \mathrm{PP}$ & 7,52 & {$[0,92 ; 61,34]$} & 0,06 \\
\hline \multirow{2}{*}{ Posição = ante } & Pessoa verbal $=1 \mathrm{PP}$ & - & - & - \\
\hline & Pessoa verbal $=3 \mathrm{PP}$ & 0,4 & {$[0,21 ; 0,75]$} & 0,005 \\
\hline \multirow{3}{*}{ Pessoa verbal $=1 \mathrm{PP}$} & Posição = posposta & - & - & - \\
\hline & Posição = intercalada & 1,11 & {$[0,14 ; 8,99]$} & 0,921 \\
\hline & Posição = anteposta & 85,96 & {$[54,71 ; 135,06]$} & 0 \\
\hline \multirow{3}{*}{ Pessoa verbal $=3 \mathrm{PP}$} & Posição = posposta & - & - & - \\
\hline & Posição = intercalada & 10,06 & {$[7,68 ; 13,17]$} & 0 \\
\hline & Posição = anteposta & 40,93 & {$[25,39 ; 65,98]$} & 0 \\
\hline Ano & & 0,98 & {$[0,96 ; 0,99]$} & 0,002 \\
\hline
\end{tabular}

Considerando-se a Posição = Posposta, houve diferença significativa $(\mathrm{p}=$ 0,011 ) entre as pessoas verbais, sendo que a chance de INFflex ocorrer com $3 \mathrm{PP}$ foi $0,83[0,72 ; 0,96]$ vezes a chance de ocorrer com $1 \mathrm{PP}$. Considerando a Posição = Intercalada, não houve diferença significativa $(\mathrm{p}=0,060)$ entre as pessoas verbais, sendo que a chance de INFflex ocorrer com 3PP foi 7,52 $[0,92 ; 61,34]$ vezes a chance de ocorrer com 1PP. Considerando a Posição = Anteposta, houve diferença significativa $(\mathrm{p}=0,005)$ entre as pessoas verbais, sendo que a chance de INFflex ocorrer com 3PP foi $0,40[0,21 ; 0,75]$ vezes a chance de ocorrer com 1PP, portanto, menor. Desse modo, em orações adverbiais antepostas a chance de INFflex ocorrer é maior com 1PP $(p=0,005)$.

Considerando-se a Pessoa Verbal $=1 \mathrm{PP}$, houve diferença significativa $(p<0.001)$ entre as posições posposta e anteposta, uma vez que a chance de INFflex ocorrer em orações antepostas foi 85,96 [54,71; 135,06] vezes maior. Considerando a Pessoa Verbal $=3 \mathrm{PP}$, houve diferença significativa $(p<0.001)$ entre as posições. Tomando a posição posposta como valor de referência, 
a chance de INFflex ocorrer foi 10,06 [7,68; 13,17] vezes maior na posição intercalada e 40,93 [25,39; 65,98] vezes maior na posição anteposta.

No que diz respeito às demais variáveis - Verbo, Área e Ano -, os resultados desse modelo foram semelhantes aos do modelo final sem a interação.

\subsubsection{Modelagem GLMM: Complementos de adjetivos}

A Tabela 4.6 apresenta o modelo logístico com efeitos mistos para INFflex antes (inicial) e depois (final) de aplicar o Backward.

Tabela 4.6 Modelo Logístico com efeitos mistos para INFflex em complementos de adjetivos

\begin{tabular}{|c|c|c|c|c|c|c|}
\hline \multirow{2}{*}{ Variáveis } & \multicolumn{3}{|c|}{ Modelo inicial } & \multicolumn{3}{|c|}{ Modelo final } \\
\hline & O.R ${ }^{1}$ & I.C - 95\% & $p$ & O. $\mathbf{R}^{1}$ & I.C - 95\% & $p$ \\
\hline Verbo $=$ outros verbos & - & - & - & - & - & - \\
\hline Verbo $=$ verbo ser & 82,06 & {$[49,05 ; 137,28]$} & 0 & 82,06 & {$[49,06 ; 137,26]$} & 0 \\
\hline Área = Biológicas & - & - & - & & & \\
\hline Área = Exatas & 1,03 & {$[0,57 ; 1,86]$} & 0,918 & & & \\
\hline Área = Humanas & 1,07 & {$[0,67 ; 1,69]$} & 0,776 & & & \\
\hline Sexo = Feminino & - & - & - & - & - & - \\
\hline Sexo = Masculino & 1,69 & {$[1,15 ; 2,47]$} & 0,007 & 1,69 & {$[1,15 ; 2,47]$} & 0,007 \\
\hline Pessoa verbal $=1 \mathrm{PP}$ & - & - & - & - & - & - \\
\hline Pessoa verbal $=3 \mathrm{PP}$ & 7,96 & {$[1,94 ; 32,65]$} & 0.004 & 7,91 & {$[1,93 ; 32,40]$} & 0,004 \\
\hline Ano & 0,96 & {$[0,92 ; 0,99]$} & 0,024 & 0,96 & {$[0,92 ; 0,99]$} & 0,023 \\
\hline
\end{tabular}

${ }^{1}$ Odds-Ratio (Razão de Chances)

Diferentemente dos resultados relativos às adverbiais, a variável sexo se mostrou significativa para os dados de infinitivo como complementos de adjetivos, sendo que os homens apresentaram chance de INFflex 1,69 [1,15; $2,43]$ vezes maior que as mulheres $(\mathrm{p}=0,007)$. O verbo ser apresentou uma chance de ser flexionado $82,06[49,06 ; 137,26]$ vezes maior que a chance dos demais verbos $(p<0,001)$.

Considerando-se a variável Pessoa verbal, também verificou-se uma diferença em relação aos resultados dos dados de INFflex em orações adverbiais. Enquanto no modelo sem interação das adverbiais a chance de INFflex ocorrer foi maior com a 1PP, em complementos de adjetivos, a chance de INFflex ocorrer com a $3 \mathrm{PP}$ foi $7,91[1,93 ; 32,40]$ vezes maior que a chance de ocorrer com 1PP $(\mathrm{p}=0,004)$. 
No que concerne à variável Ano, assim como com os infinitivos em orações adverbiais, a cada acréscimo de um ano, a chance de INFflex ocorrer foi 0,96 $[0,92 ; 0,99]$ vezes a chance do ano anterior $(\mathrm{p}=0,023)$ : a chance de INFflex ocorrer em complementos de adjetivos se mostrou menor a cada ano.

A Figura 4.19 apresenta o log das Razões de Chances para os efeitos aleatórios dos adjetivos preposicionados. Nesse modelo, a variável item_preposicionado possui 150 níveis. Na figura 4.19 apresentam-se apenas os níveis que apresentaram log da Razão de Chances significativa, isto é, apenas itens cujos intervalos de confiança não contêm o valor 0 , ou seja, itens que apresentam chance de INFflex diferente da chance média.

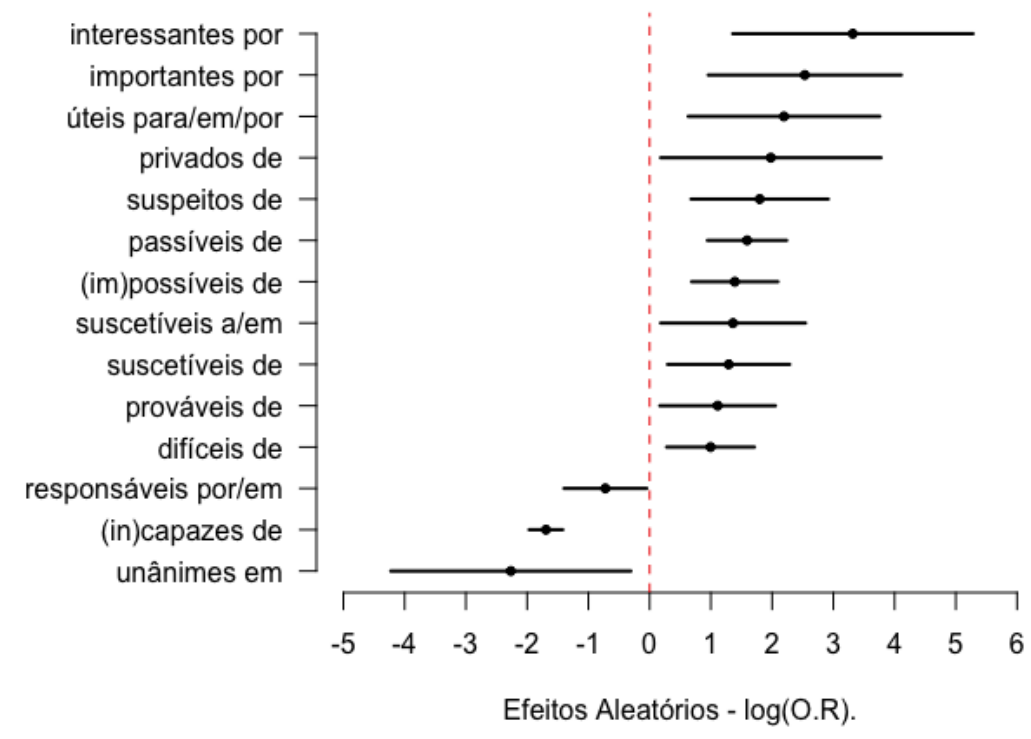

Figura 4.19 Efeitos aleatórios de adjetivos

A chance de INFflex ocorrer com os itens "importantes por", "úteis para/em/por", "privados de", "suspeitos de", "(im)possíveis de", "suscetíveis a/em", "suscetíveis de", "prováveis de" e "difíceis de" foi significativamente maior que a média dos demais itens - indicada no gráfico pelo valor 0 . Por sua vez, com os itens "responsáveis por/em", "(in)capazes de" e "unanimes em" a chance de ocorrência de INFflex foi menos que a média dos adjetivos. 


\subsubsection{Modelagem GLMM: Complementos de substan- tivos}

A Tabela 4.7 apresenta o modelo logístico com efeitos mistos para INFflex antes (inicial) e depois (final) de aplicar o Backward.

Tabela 4.7 Modelo Logístico com efeitos mistos para INFflex em complementos de substantivos

\begin{tabular}{lccc|ccc}
\hline \multirow{2}{*}{ Variáveis } & \multicolumn{3}{c|}{ Modelo inicial } & \multicolumn{3}{c}{ Modelo final } \\
\cline { 2 - 7 } & $\mathbf{O . \mathbf { R } ^ { \mathbf { 1 } }}$ & $\mathbf{I . C} \mathbf{- 9 5 \%}$ & $\boldsymbol{p}$ & $\mathbf{O . \mathbf { R } ^ { \mathbf { 1 } }}$ & I.C - 95\% & $\boldsymbol{p}$ \\
\hline Verbo = outros verbos & - & - & - & - & - & - \\
Verbo = verbo ser & 88,42 & 52,$45 ; 149,06$ & 0 & 88,82 & 52,$69 ; 149,73$ & 0 \\
\hline Área = Biológicas & - & - & - & - & - & - \\
Área = Exatas & 2,53 & {$[1,31 ; 4,89]$} & 0,006 & 2,43 & {$[1,26 ; 4,66]$} & 0,008 \\
Área = Humanas & 1,04 & {$[0,63 ; 1,71]$} & 0,884 & 1,02 & {$[0,62 ; 1,69]$} & 0,929 \\
\hline Sexo = Feminino & - & - & - & - & - & - \\
Sexo = Masculino & 0,91 & {$[0,61 ; 1,35]$} & 0,625 & - & - & - \\
\hline Pessoa verbal = 1PP & - & - & - & - & - & - \\
Pessoa verbal = 3PP & 0,23 & {$[0,15 ; 0,34]$} & 0 & 0,23 & {$[0,15 ; 0,34]$} & 0 \\
\hline Ano & 0,97 & {$[0,94 ; 1,01]$} & 0,203 & - & - & - \\
\hline 1 Odds-Ratio (Razão de Chances)
\end{tabular}

${ }^{1}$ Odds-Ratio (Razão de Chances)

Verificou-se que o verbo ser apresentou chance de flexão 88,82 [52,69; $149,73]$ vezes maior de ser flexionado que os demais verbos. A variável Pessoa verbal também se mostrou significativa: a chance de INFflex ocorrer com a $3 \mathrm{PP}$ foi $0,23[0,150,34]$ vezes a chance de INFflex ocorrer com a $1 \mathrm{PP}$ $(p<0.001)$. Assim como nas adverbiais e diferentemente dos complementos de adjetivos, favorece o emprego de INFflex em complementos de substantivos.

Em relação às áreas, tomando como base a área de Biológicas, a chance de flexão foi $2,43[1,26 ; 4,66]$ vezes maior nas teses da área de Exatas ( $\mathrm{p}=$ 0,008).

As variáveis Sexo e Ano foram excluídas do modelo final. Sendo assim, esse foi o único contexto sintático no qual a chance de INFflex ocorrer não diminui a cada ano.

A Figura 4.20 apresenta o log das Razões de Chances para os efeitos aleatórios dos itens preposicionados, nesse caso, dos substantivos. 


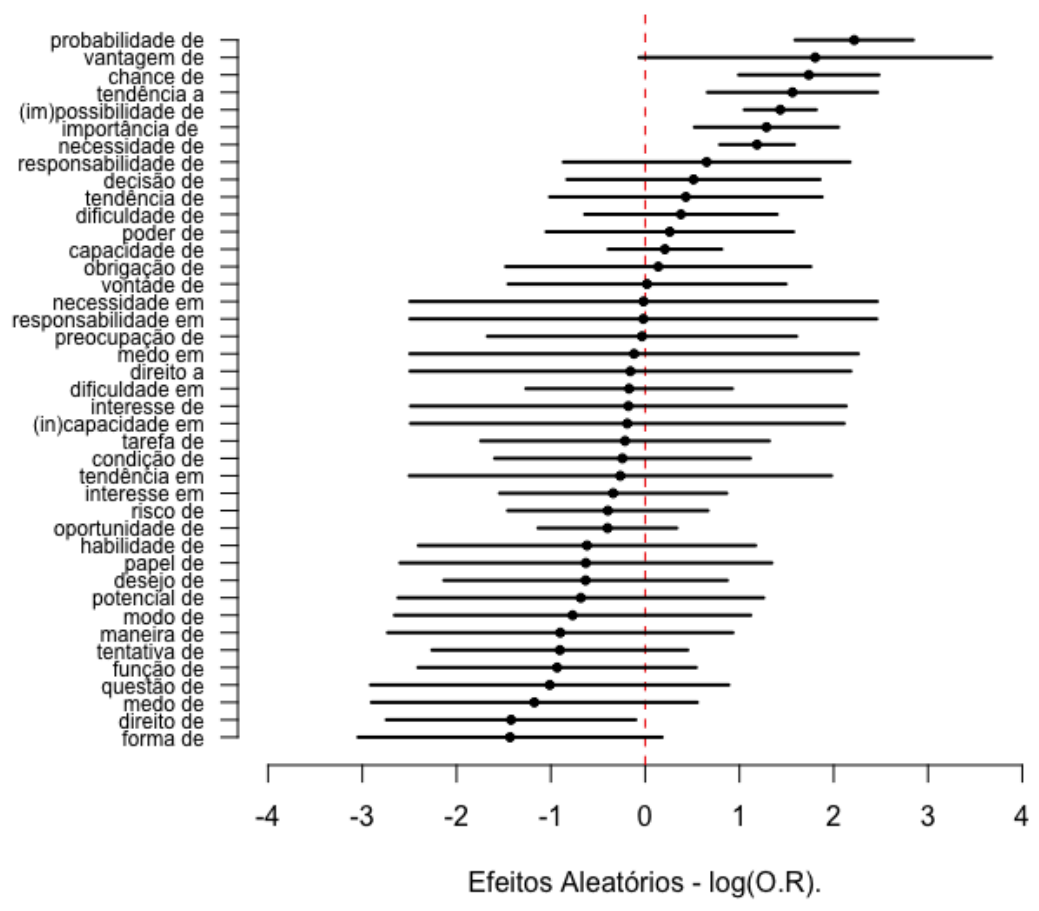

Figura 4.20 Efeitos aleatórios de substantivos

Os substantivos "probabilidade de", "chance de", "tendência a", "(im)possibilidade de", "importância de" e "necessidade de" apresentaram chance de INFflex significativamente maior que a chance média. O substantivo "direito de", por sua vez, apresentou chance de INFflex significativamente menor que a chance média. Os substantivos "vontade de", "necessidade de" e "poder de" não apresentaram diferença significativa na chance de INFflex, uma vez que os intervalos de confiança contêm o valor 0, ou seja, a chance de INFflex com eles é igual à chance média dos substantivos.

\subsection{Síntese}

Neste capítulo, apresentaram-se os resultados das análises descritivas e das análises multivariadas. Contrariando a hipótese de que INFflex estaria aumentando nos contextos opcionais investigados, verificou-se que há uma leve tendência de queda no seu emprego em orações adverbiais e em complemen- 
tos de adjetivos, ao passo que, em complementos de substantivos, as taxas permanecem estáveis.

No que concerne à frequência de uso, verificaram-se maiores taxas de INFflex em orações adverbiais antepostas à oração principal e com as preposições/locuções preposicionadas antes de, ao, após, depois de e por. Em relação ao verbo ser, confirmou-se a hipótese de que ele seria mais frequentemente flexionado do que os outros verbos, o que se interpreta neste estudo como um efeito de paralelismo linguístico (Scherre, 1998). Atribui-se a alta proporção de INFflex com o verbo ser em orações adverbiais, complementos de adjetivos e complementos de nomes à presença dos particípios e predicativos plurais seguintes ao verbo: nos contextos opcionais originais (Bossaglia, $2013 a$ ), portanto, tais marcas plurais estariam levando a mais marcas de plural. A alta frequência de INFflex com o verbo ser aponta, ainda, para um forte arraigamento de INFflex nesses contextos sintáticos. Além dos significados sociais associados à variante flexionada potencialmente envolvidos, é plausível supor que é a partir de exemplares frequentes como esse que o emprego de INFflex está se expandindo para novos contextos sintáticos. 


\section{5 \\ Estudo de percepção}

Tal como discute o capítulo 2, este estudo se insere no campo da Sociolinguística Cognitiva e adota a perspectiva sociocognitiva delineada por Croft (2000), cuja teoria de mudança linguística baseada no uso - a teoria de seleção de enunciados - prevê que a propagação de inovações linguísticas entre falantes de uma comunidade de fala depende não apenas da frequência de uso das variantes, mas também dos valores sociais que se associam a elas. Sendo assim, além do interesse na frequência de uso de INFflex, esta tese busca verificar se ouvintes são percebidos mais positivamente (mais educados, mais formais, mais inteligentes) na presença de INFflex (por oposição a INFØ), inclusive em casos em que INFflex é avaliado como um erro gramatical (Almeida, 2009 [1943]; Bechara, 2009).

Diante de usos hipercorrigidos tais como em 1, 2 e 3, encontrados nas teses do Corpus Pós_Usp, aventa-se a hipótese de que INFflex pode ter algum valor positivo de modo que falantes podem "acreditar" que as formas flexionadas são "sempre" prescritivamente corretas.

(1) Muitos misturam-se às classes que estão sendo dispensadas por falta de professores para poderem assim fugirem das aulas. (psico01M3)

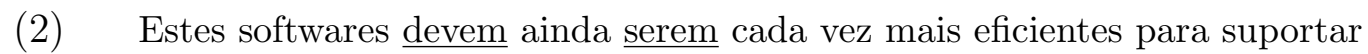
o processamento de uma grande quantidade de informações. (poli04M4)

(3) Devem então serem implementadas medidas para prevenir estas falhas ou inverter tendências adversas reveladas pelo processamento dessa informação. (poli99M6) 
Para testar a hipótese de que valores positivos estariam associando-se a INFflex, realizou-se um experimento de percepção sociolinguística com a técnica de estímulos pareados ${ }^{1}$ (Lambert et al 1960; Campbell-Kibler 2006, 2008, Mendes \& Oushiro, Oushiro 2015, Mendes 2016). O experimento consistiu da apresentação de estímulos auditivos a participantes que, depois de ouvir cada um deles, responderam a um questionário a respeito de suas impressões sobre os falantes.

Não se fez nenhuma pergunta direta, aos participantes, em momento algum, especificamente a respeito de INFflex ou INF $\varnothing$ - ou seja, as reações deles, tal como se preconiza com esse tipo de experimento, é inconsciente com respeito às formas linguísticas em si. Nesse sentido, formaram-se "falsos pares" de estímulos que diferiam entre si exclusivamente quanto à flexão do infinitivo. Cada "falso par" tinha, portanto, um estímulo com INFflex e outro com INFØ. A lógica desse tipo de experimento está em verificar como um mesmo falante é percebido quando ouvido em cada um dos estímulos de um falso par: como se trata de estímulos "quase idênticos", atribuem-se diferenças nas percepções à única diferença que há entre os estímulos, ou seja, à variante linguística investigada.

Hipoteticamente, os falantes podem estar atribuindo valores sociais positivos a INFflex qualquer que seja o contexto sintático. Neste trabalho, optou-se por utilizar, na confecção dos estímulos: (i) orações adverbiais finais (um dos contextos sintáticos opcionais investigados no estudo de produção) e (ii) as construções com infinitivos que servem de complemento a verbos modais (contextos nos quais o emprego de INFflex é considerado uso hipercorrigido).

Com esse experimento, procurou-se responder às seguintes questões: INFflex leva a percepções mais "positivas" dos falantes? Os falantes são percebidos como mais escolarizados/inteligentes/formais ao usar INFflex? Há diferenças nas percepções sobre os ouvintes a depender dos contextos sintáticos nos quais o infinitivo ocorre ou, ainda, a depender da pessoa verbal?

\footnotetext{
1 Matched-guised technique.
} 


\subsection{Desenho do experimento}

\subsubsection{Preparação dos estímulos auditivos}

Com o objetivo de investigar se as percepções dos falantes diante de INFflex e INFØ e a depender do contexto sintático e da pessoa verbal - 1PP e 3PP -, desenvolveram-se estímulos com infinitivos em orações adverbiais (nas quais o emprego de INFflex é considerado opcional) e em complementos de verbos modais (nos quais o emprego de INFflex é considerado hipercorrigido), com 1PP e com 3PP. No que diz respeito ao tema, optou-se por utilizar sentenças relacionadas, em certa medida, ao universo da tecnologia, considerado um tema neutro, evitando-se temas polêmicos como política e futebol, por exemplo. A tabela apresenta os 4 estímulos em suas versões com INFflex e INF $\varnothing$.

\begin{tabular}{|c|c|l|l|}
\cline { 2 - 4 } \multicolumn{2}{c|}{} & \multicolumn{1}{c|}{ INFflex } & \multicolumn{1}{c|}{ INFØ } \\
\hline $\begin{array}{c}\text { Oração adverbial } \\
\text { (contexto no qual INFflex é } \\
\text { opcional) }\end{array}$ & $1 \mathrm{PP}$ & $\begin{array}{l}\text { Aqui em casa, além da televisão, nós também usamos o o } \\
\text { computador 'pra' assistirmos a filmes e séries. }\end{array}$ & $\begin{array}{l}\text { Aqui em casa, além da televisão, nós também usamos o } \\
\text { computador 'pra' assistir a filmes e séries. }\end{array}$ \\
\cline { 2 - 5 } & $3 \mathrm{PP}$ & $\begin{array}{l}\text { Hoje em dia, com diversos aplicativos novos, muitas } \\
\text { pessoas usam a internet 'pra' fazerem ligações. }\end{array}$ & $\begin{array}{l}\text { Hoje em dia, com diversos aplicativos novos, muitas } \\
\text { pessoas usam a internet 'pra' fazer ligações. }\end{array}$ \\
\hline $\begin{array}{c}\text { Complemento de verbo modal } \\
\text { (contexto no qual INFflex é } \\
\text { considerado hipercorreção) }\end{array}$ & $1 \mathrm{PP}$ & $\begin{array}{l}\text { No caso da televisão a cabo, só depois de 12 meses nós } \\
\text { podemos cancelarmos a assinatura. }\end{array}$ & $\begin{array}{l}\text { No caso da televisão a cabo, só depois de 12 meses nós } \\
\text { podemos cancelar a assinatura. }\end{array}$ \\
\cline { 2 - 4 } & Com tantos aplicativos infantis hoje em dia, as crianças \\
podem aprenderem muito. & $\begin{array}{l}\text { Com tantos aplicativos infantis hoje em dia, as crianças } \\
\text { podem aprender muito. }\end{array}$ \\
\hline
\end{tabular}

Quadro 5.1 Sentenças utilizadas como estímulos.

Gravaram-se, então, 4 falantes diferentes - dois homens e duas mulheres -, lendo essas frases, do modo mais espontâneo possível, nas versões com INFflex e as versões com INF $\varnothing .^{2}$ Cada falante foi gravado inúmeras vezes falando as 8 sentenças e foram, então, selecionadas as realizações mais naturais. Embora cada falante tenha gravado as 8 sentenças, apenas os áudios com as versões com INFflex foram, de fato, utilizados. Para garantir que a única diferença entre os estímulos de cada par fosse a presença ou não de INFflex - e que nem mesmo a entonação fosse diferente -, os arquivos de áudio com as versões com INFflex foram manipulados no Praat (Boersma \& Weenink, 2017). Nesse

2 Para a gravação, utilizou-se um iPhone modelo SE. 
software, foram cortadas as flexões - ou seja, INFflex - no sentido de se produzirem os respectivos estímulos com INFØ. A Figura 5.1 ilustra a tela do Praat, com destaque para o trecho referente a "rem" - da sentença "Com tantos aplicativos infantis hoje em dia, as crianças podem aprenderem muito". Especificamente nesse caso, cortou-se a flexão -em e também o -r, no sentido de produzir um estímulo com INFØ ("Com tantos aplicativos hoje em dia, as crianças podem aprendê muito"), formando-se, portanto, um dos pares de estímulos do experimento (aquele que está na última linha da Tabela 5.1.

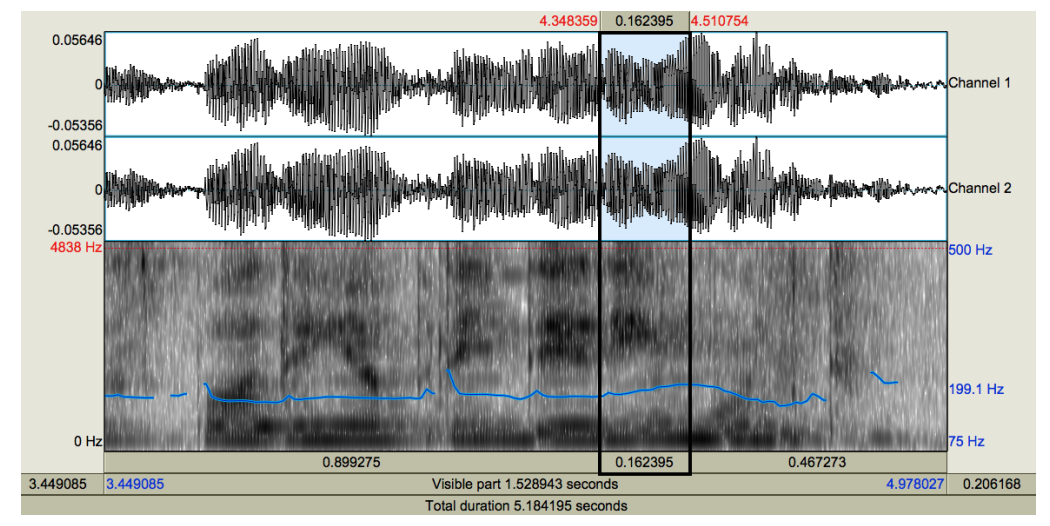

Figura 5.1 Tela do Praat com exemplo de flexão.

Manipulados os arquivos de áudio e formados os 4 falsos pares para cada falante, chegou-se a um total de 32 estímulos:

\begin{tabular}{|c|c|c|c|c|c|}
\hline & \multicolumn{2}{|c|}{ Homem 1} & & \multicolumn{2}{|c|}{ Homem 2} \\
\hline & áudio original & áudio manipulado & & áudio original & áudio manipulado \\
\hline 1 & Adverbial1PP_INFflex & Adverbial1PP_INFØ & 1 & Adverbial1PP_INFflex & Adverbial1PP_INFØ \\
\hline 2 & Adverbial3PP_INFflex & Adverbial3PP_INFØ & 2 & Adverbial3PP_INFflex & Adverbial3PP_INFØ \\
\hline 3 & Modal1PP_INFflex & Modal1PP_INFØ & 3 & Modal1PP_INFflex & Modal1PP_INFØ \\
\hline 4 & Modal3PP_INFflex & Modal3PP_INF $\emptyset$ & 4 & Modal3PP_INFflex & Modal3PP_INF $\varnothing$ \\
\hline \multicolumn{3}{|c|}{ Mulher 1} & & \multicolumn{2}{|c|}{ Mulher 2} \\
\hline & áudio original & áudio manipulado & & áudio original & áudio manipulado \\
\hline 1 & Adverbial1PP_INFflex & Adverbial1PP_INFØ & 1 & Adverbial1PP_INFflex & Adverbial1PP_INFØ \\
\hline 2 & Adverbial3PP_INFflex & Adverbial3PP_INFØ & 2 & Adverbial3PP_INFflex & Adverbial3PP_INFØ \\
\hline 3 & Modal1PP_INFflex & Modal1PP_INFØ & 3 & Modal1PP_INFflex & Modal1PP_INFØ \\
\hline 4 & Modal3PP_INFflex & Modal3PP_INF $\varnothing$ & & Modal3PP_INFflex & Modal3PP_INF $\varnothing$ \\
\hline
\end{tabular}

Quadro 5.2 Estímulos pareados após a manipulação dos arquivos de áudio. 


\subsubsection{Formação dos conjuntos de estímulos}

Para que cada participante não ouvisse a mesma voz mais de uma vez (Campbell-Kibler 2008; Mendes 2014), cada um deveria ouvir 4 estímulos 1 de cada falante. Com isso em mente, organizaram-se 8 conjuntos com 4 estímulos cada. Outro critério para a formação dos conjuntos foi que cada um deles contivesse uma combinação entre contexto sintático e pessoa verbal, sendo que 2 estímulos teriam INFflex e 2 teriam INFØ.

\begin{tabular}{|l|c|c|c|c|c|c|c|c|}
\hline \multicolumn{1}{|c|}{ A1 } & \multicolumn{2}{|c|}{ Homem 1 } & \multicolumn{2}{c|}{ Homem 2 } & \multicolumn{2}{|c|}{ Mulher 1 } & \multicolumn{2}{|c|}{ Mulher 2 } \\
\hline Adverbial 1PP & flex & $\varnothing$ & flex & $\varnothing$ & flex & $\varnothing$ & flex & $\emptyset$ \\
\hline Adverbial 3PP & flex & $\varnothing$ & flex & $\varnothing$ & flex & $\varnothing$ & flex & $\emptyset$ \\
\hline Modal 1PP & flex & $\varnothing$ & flex & $\varnothing$ & flex & $\varnothing$ & flex & $\varnothing$ \\
\hline Modal 3PP & flex & $\varnothing$ & flex & $\varnothing$ & flex & $\varnothing$ & flex & $\varnothing$ \\
\hline
\end{tabular}

\begin{tabular}{|l|c|c|c|c|c|c|c|c|}
\hline \multicolumn{1}{|c|}{ A2 } & \multicolumn{2}{|c|}{ Homem 1 } & \multicolumn{2}{c|}{ Homem 2 } & \multicolumn{2}{c|}{ Mulher 1 } & \multicolumn{2}{c|}{ Mulher 2 } \\
\hline Adverbial 1PP & flex & $\varnothing$ & flex & $\varnothing$ & flex & $\varnothing$ & flex & $\emptyset$ \\
\hline Adverbial 3PP & flex & $\varnothing$ & flex & $\varnothing$ & flex & $\emptyset$ & flex & $\emptyset$ \\
\hline Modal 1PP & flex & $\varnothing$ & flex & $\varnothing$ & flex & $\emptyset$ & flex & $\emptyset$ \\
\hline Modal 3PP & flex & $\varnothing$ & flex & $\varnothing$ & flex & $\varnothing$ & flex & $\emptyset$ \\
\hline
\end{tabular}

\begin{tabular}{|l|c|c|c|c|c|c|c|c|}
\hline \multicolumn{1}{|c|}{ B1 } & \multicolumn{2}{|c|}{ Homem 1 } & \multicolumn{2}{c|}{ Homem 2 } & \multicolumn{2}{c|}{ Mulher 1 } & \multicolumn{2}{c|}{ Mulher 2 } \\
\hline Adverbial 1PP & flex & $\varnothing$ & flex & $\emptyset$ & flex & $\varnothing$ & flex & $\emptyset$ \\
\hline Adverbial 3PP & flex & $\varnothing$ & & & flex & $\emptyset$ & flex & $\emptyset$ \\
\hline Modal 1PP & flex & $\varnothing$ & flex & $\varnothing$ & flex & $\varnothing$ & flex & $\emptyset$ \\
\hline Modal 3PP & flex & $\varnothing$ & flex & $\varnothing$ & flex & $\varnothing$ & flex & \\
\hline
\end{tabular}

\begin{tabular}{|l|c|c|c|c|c|c|c|c|}
\hline \multicolumn{1}{|c|}{ B2 } & \multicolumn{2}{|c|}{ Homem 1 } & \multicolumn{2}{c|}{ Homem 2 } & \multicolumn{2}{c|}{ Mulher 1 } & \multicolumn{2}{c|}{ Mulher 2 } \\
\hline Adverbial 1PP & & & flex & $\varnothing$ & flex & $\varnothing$ & flex & $\emptyset$ \\
\hline Adverbial 3PP & flex & $\emptyset$ & flex & $\varnothing$ & flex & $\varnothing$ & flex & $\emptyset$ \\
\hline Modal 1PP & flex & $\varnothing$ & flex & $\varnothing$ & flex & $\varnothing$ & flex & $\emptyset$ \\
\hline Modal 3PP & flex & $\varnothing$ & flex & $\varnothing$ & flex & $\varnothing$ & flex & $\emptyset$ \\
\hline
\end{tabular}

\begin{tabular}{|l|c|c|c|c|c|c|c|c|}
\hline \multicolumn{1}{|c|}{ C1 } & \multicolumn{2}{|c|}{ Homem 1 } & \multicolumn{2}{c|}{ Homem 2 } & \multicolumn{2}{c|}{ Mulher 1 } & \multicolumn{2}{c|}{ Mulher 2 } \\
\hline Adverbial 1PP & flex & $\varnothing$ & flex & $\varnothing$ & flex & $\varnothing$ & flex & $\emptyset$ \\
\hline Adverbial 3PP & flex & $\varnothing$ & flex & $\varnothing$ & flex & $\varnothing$ & flex & $\emptyset$ \\
\hline Modal 1PP & flex & $\varnothing$ & flex & $\varnothing$ & flex & $\varnothing$ & flex & $\emptyset$ \\
\hline Modal 3PP & flex & $\varnothing$ & flex & $\varnothing$ & flex & $\varnothing$ & flex & $\emptyset$ \\
\hline
\end{tabular}

\begin{tabular}{|l|c|c|c|c|c|c|c|c|}
\hline \multicolumn{1}{|c|}{ C2 } & \multicolumn{2}{|c|}{ Homem 1 } & \multicolumn{2}{c|}{ Homem 2 } & \multicolumn{2}{c|}{ Mulher 1 } & \multicolumn{2}{c|}{ Mulher 2 } \\
\hline Adverbial 1PP & flex & $\varnothing$ & flex & $\varnothing$ & flex & $\emptyset$ & flex & $\emptyset$ \\
\hline Adverbial 3PP & flex & $\varnothing$ & flex & $\varnothing$ & flex & $\varnothing$ & flex & $\emptyset$ \\
\hline Modal 1PP & flex & $\varnothing$ & flex & $\varnothing$ & flex & $\varnothing$ & flex & $\emptyset$ \\
\hline Modal 3PP & flex & $\varnothing$ & flex & $\varnothing$ & flex & $\varnothing$ & flex & $\varnothing$ \\
\hline
\end{tabular}

\begin{tabular}{|l|c|c|c|c|c|c|c|c|}
\hline \multicolumn{1}{|c|}{ D1 } & \multicolumn{2}{|c|}{ Homem 1 } & \multicolumn{2}{c|}{ Homem 2 } & \multicolumn{2}{c|}{ Mulher 1 } & \multicolumn{2}{c|}{ Mulher 2 } \\
\hline Adverbial 1PP & flex & $\varnothing$ & flex & $\emptyset$ & flex & $\emptyset$ & flex & $\emptyset$ \\
\hline Adverbial 3PP & flex & $\varnothing$ & flex & $\varnothing$ & flex & $\varnothing$ & flex & $\emptyset$ \\
\hline Modal 1PP & flex & $\varnothing$ & flex & $\varnothing$ & flex & $\varnothing$ & flex & $\emptyset$ \\
\hline Modal 3PP & flex & $\varnothing$ & flex & $\varnothing$ & flex & $\varnothing$ & flex & $\emptyset$ \\
\hline
\end{tabular}

\begin{tabular}{|l|c|c|c|c|c|c|c|c|}
\hline \multicolumn{1}{|c|}{ D2 } & \multicolumn{2}{|c|}{ Homem 1 } & \multicolumn{2}{c|}{ Homem 2 } & \multicolumn{2}{c|}{ Mulher 1 } & \multicolumn{2}{c|}{ Mulher 2 } \\
\hline Adverbial 1PP & flex & $\varnothing$ & flex & $\emptyset$ & flex & $\emptyset$ & flex & $\emptyset$ \\
\hline Adverbial 3PP & flex & $\varnothing$ & flex & $\emptyset$ & flex & $\emptyset$ & flex & $\emptyset$ \\
\hline Modal 1PP & flex & $\varnothing$ & flex & $\varnothing$ & flex & $\emptyset$ & flex & $\emptyset$ \\
\hline Modal 3PP & flex & $\varnothing$ & flex & $\varnothing$ & flex & $\varnothing$ & flex & $\emptyset$ \\
\hline
\end{tabular}

Quadro 5.3 Formação dos 8 conjuntos de estímulos.

O quadro 5.3 indica, em azul, o estímulo que foi incluído em cada conjunto. As células em branco representam o "falso par" desses estímulos. Comparandose os conjuntos A1 e A2, por exemplo, nota-se que os mesmos pares estão destacados, porém as células que estão em azul no conjunto A1 estão em branco no A2. A1 e A2 têm, portanto, os mesmos pares destacados, diferindo um do outro apenas em relação a qual estímulo de cada par serviram de estímulo para certos ouvintes. O mesmo procedimento foi feito para os conjuntos B1 e B2, C1 e C2, e D1 e D2.

Dessa forma, os 32 estímulos estão distribuídos entre os 8 conjuntos, no sentido de que todos fossem ouvidos: cada "voz" foi ouvida em todos os contextos sintáticos e pessoas verbais, com INFflex e com INF $\varnothing$. 


\subsubsection{Aplicação dos questionários}

Para a aplicação dos questionários, utilizou-se a plataforma online Qualtrics, ${ }^{3}$ na qual inseriram-se: (i) os 32 áudios com os estímulos auditivos, já agrupados de acordo com os conjuntos de dados (Quadro 5.3), (ii) o questionário que os participantes deveriam responder imediatamente após ouvir cada uma das vozes apresentadas (Anexo B); e (iii) o questionário demográfico que os participantes deveriam responder ao fim da pesquisa, com perguntas sobre sua idade, nível de escolaridade, ocupação, residência e local de nascimento.

Programou-se a plataforma para atribuir, aleatoriamente, um dos 8 conjuntos de dados a cada participante que acessasse a pesquisa. Após a página de apresentação (Figura 5.2), o participante ouviria, então, os 4 estímulos do conjunto a ele atribuído. ${ }^{4}$ Definiu-se, ainda, que a ordem de apresentação dos estímulos de cada conjunto também seria aleatória, evitando-se, assim, possíveis efeitos de priming sintático. ${ }^{5}$

3 https://www.qualtrics.com/

Agradeço ao Programa de Pós-Graduação em Linguística da USP pelo financiamento da licença de uso dessa ferramenta.

4 Os participantes não tinham conhecimento algum sobre essa atribuição de conjuntos, feita automaticamente pelo programa a cada acesso à pesquisa.

5 Esse fenômeno - também chamado de priming estrutural e persistência sintática - diz respeito à tendência de repetição de estruturas sintáticas recém produzidas ou ouvidas, além de maior facilidade no processamento de estruturas sintáticas semelhantes àquelas com as quais se acaba de ter contato (Gries 2005, Bock, 1986). Nesse sentido, se todos os participantes ouvissem os estímulos sempre na mesma ordem, não seria possível saber se as respostas estimuladas pela segunda voz em A1, por exemplo, teriam sido condicionadas pela primeira voz. Ou ainda, se, caso todos ouvissem primeiro os falantes homens, as respostas às falas das mulheres teriam sido condicionadas pelas anteriores. 


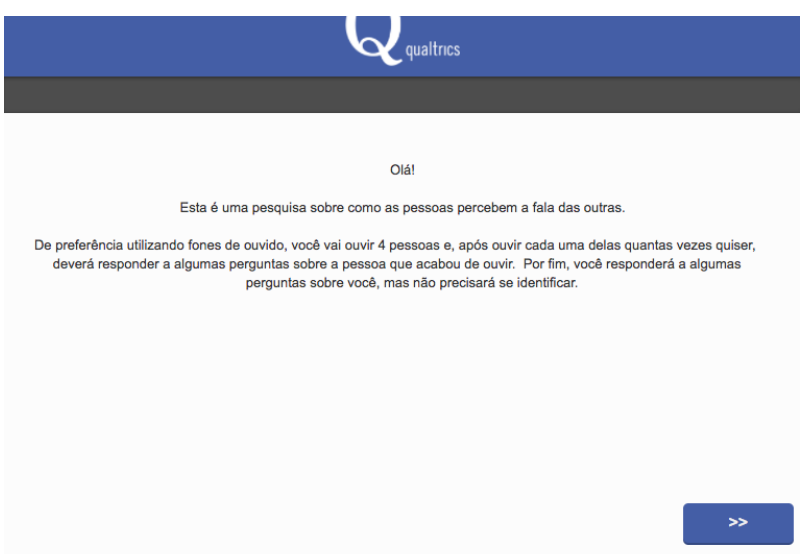

Figura 5.2 Tela de apresentação da pesquisa.

Como se pode ver na Figura 5.3, logo após o áudio, o questionário trazia 5 escalas de diferenciais semânticos, com opções de respostas que variam de um extremo a outro. ${ }^{6}$ Em vez de perguntas de resposta "sim" ou "não" como "Você acha que essa pessoa é escolarizada?" ou "Você acha que essa pessoa é inteligente?-, essas escalas permitem acessar níveis de opinião, sendo adequadas para experimentos como este.
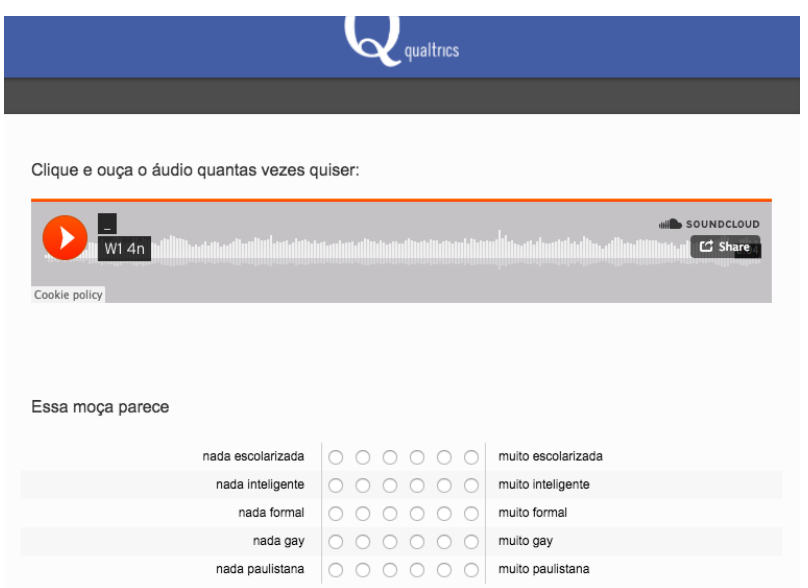

Figura 5.3 Tela de apresentação dos áudios e de um trecho do questionário com as escalas

Além das escalas relacionadas à escolaridade, inteligência e formalidade,

6 Após as 5 escalas, também foram apresentadas questões qualitativas, como "A que classe socioeconômica você acha que essa pessoa pertence?"( ver anexo B). 
incluíram-se, ainda, a escala "soar gay" e a escala "paulistanidade". Soar gay ou não com base em INFflex se liga ao trabalho de Mendes (2016b), que trabalhou com concordância nominal e verificou que homens foram percebidos, consistentemente, como homens que soam mais masculinos quando ouvidos na sua versão sem concordância. A ideia, portanto, foi aproveitar esse experimento para verificar se haveria alguma correlação entre flexionar o infinitivo e soar gay. Quanto à ideia de paulistanidade, trata-se também de aproveitar o experimento para verificar se haveria alguma correlação entre flexionar e soar mais ou menos paulistano - não porque há uma hipótese de partida para isso, mas porque esse trabalho se inclui num conjunto de trabalhos que vêm fazendo esse questionamento, tais como: Oushiro (2015) e Soriano (2016) sobre a pronúncia do (-r), e Mendes (2016b) sobre o (EN).

No que diz respeito à aplicação dos questionários, o link de acesso à pesquisa foi distribuído por e-mail, redes sociais e, gentilmente, redistribuído por inúmeros amigos, colegas e participantes respondentes para pessoas de todo o país. O link também foi enviado às listas de graduação e pós-graduação da Faculdade de Filosofia, Letras e Ciências Humanas (FFLCH) da USP através do Serviço de Comunicação Social da faculdade, que prontamente concordou em colaborar com a divulgação do convite para participação na pesquisa.

Como mostram as Tabelas 5.1 e 5.2, completaram a pesquisa 411 participantes, ${ }^{7}$ dos quais $61 \%$ moram em São Paulo e na região metropolitana, e 91,24\% têm nível Superior ou Pós-graduação.

7 Graças à mobilização das redes de amigos de amigos e de colegas de colegas, foram coletadas em torno de 300 respostas em 3 dias. Após a divulgação nas listas da FFLCH, em poucas horas atingiu-se o limite máximo de respostas/participações - 415 - e a pesquisa foi fechada. Desse total, 4 foram descartadas por não terem sido completadas. 
Tabela 5.1 Distribuição dos 411 participantes de acordo com o local em que residem

\begin{tabular}{lcc}
\hline \multirow{2}{*}{ RESIDÊNCIA } & \multicolumn{2}{c}{ PARTICIPANTE } \\
& $\%$ & $\mathrm{~N}$ \\
\hline São Paulo, capital & 38,69 & 159 \\
Grande São Paulo & 22,38 & 92 \\
São Paulo, interior & 4,62 & 19 \\
Outro estado & 31,63 & 130 \\
Não responderam & 2,68 & 11 \\
\hline
\end{tabular}

Tabela 5.2 Distribuição dos 411 participantes de acordo com seu nível de escolaridade

\begin{tabular}{lcc}
\hline \multirow{2}{*}{ NÍVEL DE ESCOLARIDADE } & \multicolumn{2}{c}{ PARTICIPANTE } \\
& $\%$ & $\mathrm{~N}$ \\
\hline Ensino Fundamental 1 & 0,49 & 2 \\
Ensino Fundamental 2 & 0,49 & 2 \\
Ensino Médio & 7,79 & 32 \\
Ensino Superior & 43,55 & 179 \\
Pós-graduação & 47,69 & 196 \\
\hline
\end{tabular}

Foram respondidos, portanto, 1644 questionários (4 por cada participante), cada um referente a um estímulo ouvido. Como se vê na Figura.5.4, cada conjunto foi ouvido em torno de 50 vezes, o que significa que cada um dos 32 estímulos foi ouvido e julgado por uma média de 50 participantes. Dessa forma, o Homem 1, por exemplo, foi julgado, aproximadamente:

- 50 vezes na versão Adverbial_1PP_INFflex e 50 vezes na versão Adverbial_1PP_INF $\varnothing$;

- 50 vezes na versão Adverbial_3PP_INFflex e 50 vezes na versão Adverbial_3PP_INFØ;

- 50 vezes na versão Modal_1PP_INFflex e 50 vezes na versão Modal_1PP_INFØ;

- e 50 vezes na versão Modal_3PP_INFflex e 50 vezes na versão Modal_3PP_INFØ. 


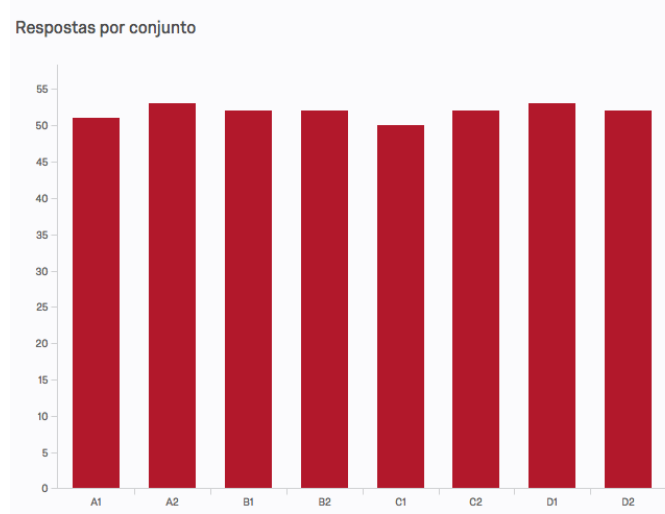

Figura 5.4 Total de participantes que completaram do experimento (411) para cada conjunto de dados que ouviram.

Relembrando a hipótese inicial deste estudo, no contexto sintático no qual INFflex é opcional - oração adverbial -, esperava-se que os 4 falantes seriam percebidos como "mais escolarizados", "mais inteligentes" e "mais formais" quando ouvidos em suas versões com INFflex em comparação às versões com INFØ. No caso do contexto sintático no qual INFflex é um exemplo de hipercorreção (complementos de modais), esperava-se que os 4 falantes seriam percebidos de modo diferente a depender do grau de escolaridade dos participantes. Esperava-se que participantes mais escolarizados perceberiam os falantes como "mais escolarizados", "mais inteligentes" e "mais formais" quando ouvidos em suas versões com INFØ e "menos escolarizados, menos inteligentes e menos formais" em suas versões com INFflex. Já em relação aos participantes menos escolarizados, a hipótese era a de que perceberiam os falantes como "mais escolarizados, inteligentes e formais" em suas versões com INFflex, demonstrando impressões positivas em relação aos usos hipercorrigidos.

\subsection{Análise dos dados}

Analisaram-se, primeiramente, as notas dadas pelos participantes nas 5 escalas perceptuais - escolarização, inteligência, formalidade, soar gay, paulistanidade - de modo a verificar se havia correlação entre as escalas. Por exemplo, 
caso um falante, a partir de um mesmo estímulo, tenha percebido a "voz" como "mais escolarizada" e "mais inteligente", essa seria uma correlação positiva. Se fosse o contrário, a correlação seria negativa. Uma análise de componentes principais (ACP) realizada no software R ( $\mathrm{R}$ Team, 2017) revelou uma correlação positiva entre as escalas escolarização, inteligência e formalidade, permitindo que elas fossem agrupadas em um mesmo componente, ao qual, seguindo Levon (2014), se deu o nome de "competência". As outras duas escalas - soar gay e paulistanidade -, por sua vez, são independentes entre si e das demais.

Tabela 5.3 Carga fatorial de 5 escalas perceptuais (Método: Análise de componentes principais com rotação varimax)

\begin{tabular}{lccc}
\hline & 'Competência' & 'Gay' & 'Paulistanidade' \\
\cline { 2 - 4 } Escolaridade & 0.89 & -0.03 & 0.04 \\
Inteligência & 0.89 & -0.03 & 0.01 \\
Formalidade & 0.75 & 0.07 & -0.05 \\
Gay & -0.03 & 1.00 & 0.00 \\
Paulistanidade & 0.02 & 0.00 & 0.99 \\
\hline SS loadings & 2.13 & 1.00 & 1.00 \\
\% Variância & 0.43 & 0.20 & 0.20 \\
Variância cumulativa & 0.43 & 0.63 & 0.83 \\
\% Explicada & 0.52 & 0.24 & 0.24 \\
\% Cumulativa & 0.52 & 0.76 & 1.00 \\
\hline
\end{tabular}

Considerando-se as questões que interessam a esta tese (5.1.1), as análises se concentraram na 'percepção de competência' de acordo com o emprego de INFflex.

De modo geral, os falantes foram julgados como "mais competentes", portanto "mais escolarizados", "mais inteligentes" e "mais formais" quando ouvidos nas versões com INFØ: 


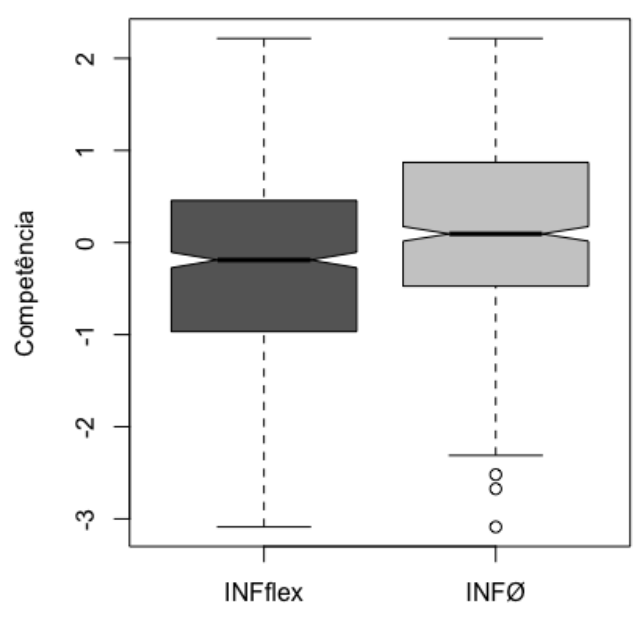

Figura 5.5 Percepção de 'competência' de acordo com INFflex x INFØ

A 'percepção de competência' foi analisada como variável dependente em modelos de regressão linear com efeitos mistos com Flexão, Pessoa verbal e Contexto sintático como efeitos fixos e Participantes e Voz como efeitos aleatórios. Pessoa verbal não se mostrou uma variável preditora significativa e foi retirada do modelo. Como se vê na tabela 5.4, são significativas as variáveis Flexão e Contexto sintático, assim como a interação entre as duas: vozes com INFflex em complementos de verbos modais foram julgadas como menos competentes do que vozes com INF $\varnothing$ em orações adverbiais.

Tabela 5.4 Resultados de um modelo de regressão linear com efeitos mistos para 'percepção de competência'

\begin{tabular}{lccccc}
\hline Efeitos fixos & Estimativa & Erro padrão & $\mathrm{df}$ & $t$ & $p$ \\
(Intercepto) & 0.24643 & 0.13214 & 380.000 & 1.865 & 0.139999 \\
FLEXAOINFflex & -0.15941 & 0.05706 & 106.540 .000 & -2.794 & $0.005303 * *$ \\
ESTRUT_SINTModal & -0.21654 & 0.05702 & 106.600 .000 & -3.797 & $0.000154 * * *$ \\
FLEXAOINFflex:ESTRUT_SINTModal & -0.30917 & 0.08079 & 106.740 .000 & -3.827 & $0.000137 * * *$ \\
\hline
\end{tabular}

Total N=1432 Efeitos aleatórios: Participante (368), Voz (4).

Analisando-se os dois contextos sintáticos separadamente, nota-se que, em ambos, os falantes foram percebidos como 'menos competentes' quando ouvidos na versão com INFflex, porém essa diferença foi mais acentuada quando os infinitivos servem de complemento a verbos modais, contextos nos 
quais INFflex é considerado uso hipercorrigido (Figura 5.6). Tal diferença é, de fato, estatisticamente significativa apenas com INFflex em complementos de verbos modais.

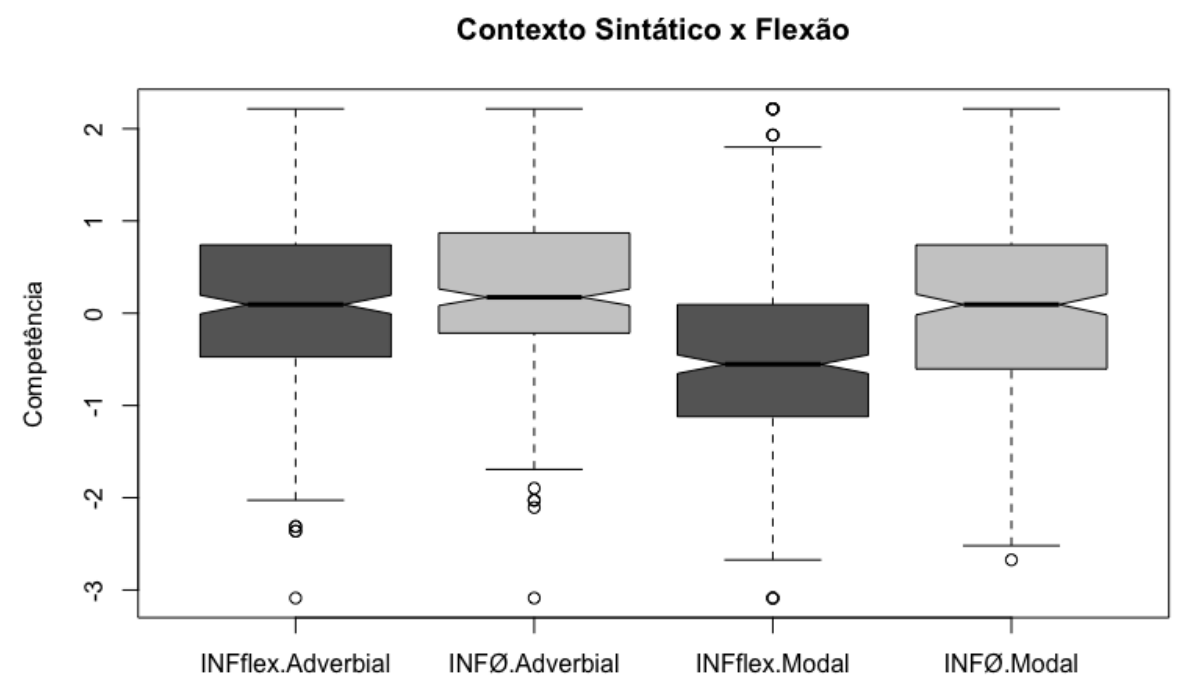

Figura 5.6 Percepção de 'competência' de acordo com INFflex x INFØ nos dois contextos sintáticos

Ainda em relação às análises dos subconjuntos de contextos sintáticos separadamente, com infinitivos em complemento de modal, Idade do participante se mostrou uma variável preditora significativa da percepção de competência das vozes a depender do emprego de INFflex ou INF $\varnothing(p=0.00832 * *)$. Como se vê na Figura 5.7, a partir dos 50 anos, quanto maior a idade, maior a rejeição por INFflex e maior a preferência por INF $\varnothing$. 


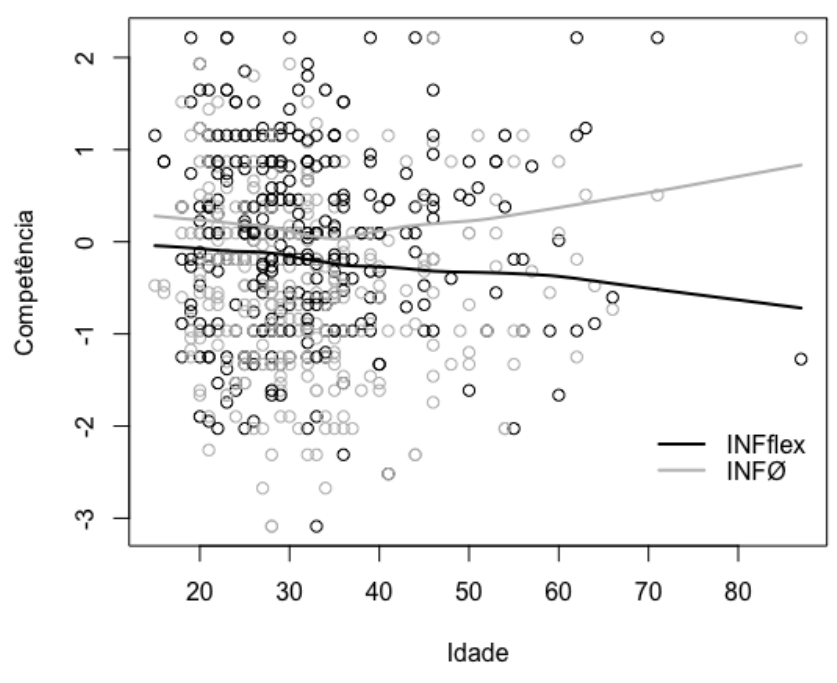

Figura 5.7 'Percepção de competência' de acordo com INFflex x INFØ em complemento de verbo modal e de acordo com a idade dos participantes

A fim de verificar se Flexão influenciou significativamente a percepção de 'competência' de todas as vozes ou se alguma delas foi percebida como mais ou menos 'competente' independentemente do estímulo, analisaram-se os subconjuntos de dados referentes a cada uma delas. ${ }^{8}$ A Figura 5.8 ilustra as diferenças nos julgamentos de 'competência' de cada uma das vozes a depender de terem sido ouvidas usando INFflex ou INFØ.

8 Testaram-se, para cada subconjunto, modelos de regressão linear e o resultado foi significativo nos modelos com Flexão como efeito fixo e Participante e Voz como efeito aleatório. 


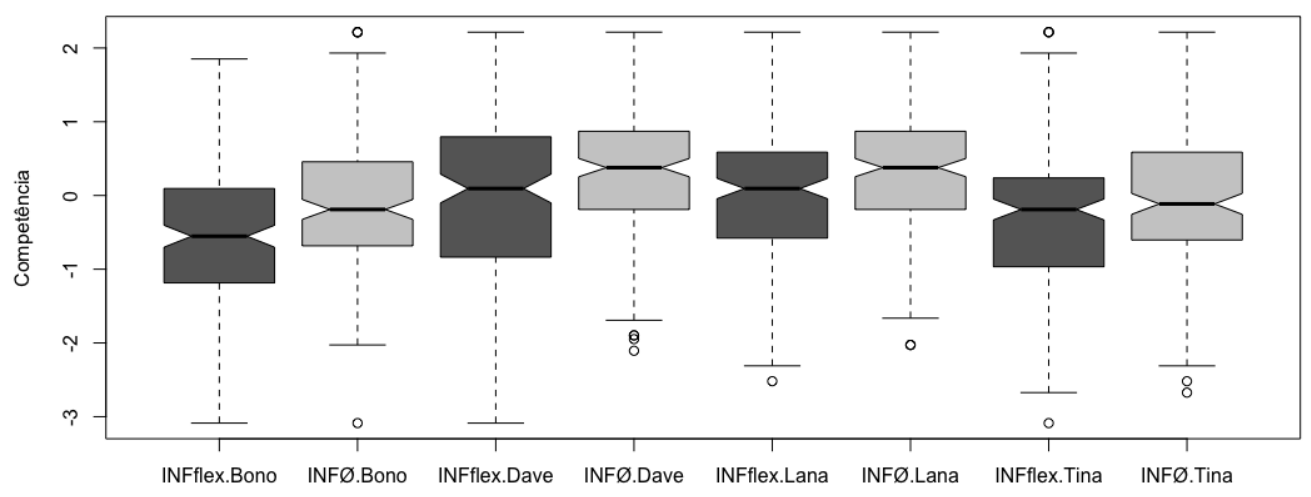

Figura 5.8 Percepção de 'competência' de cada voz de acordo com INFflex x INF $\varnothing$

A respeito da sobreposição de notches, tal como a que se nota nos boxplots referentes à Tina, Krzywinski \& Altman (2014: 119) explicam que "em geral, quando não há sobreposição dos notches dos boxplots, pode-se considerar que as medianas diferem significativamente, porém a sobreposição não descarta uma diferença significativa". ${ }^{9}$ De fato, no caso da Tina, ${ }^{10}$ embora os notches dos boxplots se sobreponham, o modelo revelou uma diferença significativa entre as respostas atribuídas a ela na presença ou não de INFflex $(p=0.0329)$. Sendo assim, os resultados indicam que as 4 vozes - Bono, Dave, Lana e Tina - foram percebidas como mais 'competentes' quando ouvidas em suas versões com INFØ $(p<0.05)$.

\subsection{Discussão}

No que diz respeito à estrutura adverbial (um contexto de opcionalidade de INFflex), esperava-se que os falantes seriam percebidos como mais 'competentes' em suas versões com INFflex, o que não se confirmou. Nesse contexto sintático, a variável Flexão não influenciou significativamente as percepções de 'competência'.

\footnotetext{
9 Original: "In general, when notches do not overlap, the medians can be judged to differ significantly, but overlap does not rule out a significant difference."

10 Bono, Dave, Lana e Tina são os nomes fictícios dos falantes cujas vozes foram julgadas no experimento.
} 
Em relação ao contexto sintático no qual INFflex é considerado um uso hipercorrigido, esperava-se um efeito de Escolaridade do participante: os mais escolarizados julgariam as vozes como menos 'competentes' nas versões com INFflex, enquanto os menos escolarizados julgariam as vozes, nesses mesmos contextos, como mais 'competentes'. Independentemente da Escolaridade do participante, as vozes foram percebidas como menos competentes em suas versões INFflex no contexto de hipercorreção, o que pode estar relacionado ao fato de que $91 \%$ dos participantes tinham, no mínimo, Ensino Superior. Estudos futuros com mais participantes de níveis de escolaridade mais baixos são necessários para que se explore a influência da variável Escolaridade do participante.

Os resultados relacionados à interação significativa entre Flexão e Idade na 'percepção de competência' das vozes - em contextos de hipercorreção são interessantes na medida em que dão pistas sobre possíveis significados sociais relacionados a INFflex. Apesar de participantes mais jovens também terem julgado falantes como menos 'competentes' nas versões com INFflex, participantes mais velhos apresentaram notas mais polarizadas: quanto mais velhos, mais positivamente julgaram versões com INF $\varnothing$ e mais negativamente versões com INFflex. Falantes mais jovens, por sua vez, foram menos extremos em seus julgamentos. Essa tendência sugere que o emprego hipercorrigido de INFflex é menos saliente para os mais jovens, que estariam, então, percebendo de modo mais neutro o que se considera "erro" na visão prescritivista.

\subsection{Síntese}

Este capítulo apresentou o teste de percepção que se desenvolveu com base na técnica de estímulos pareados (Campbell-Kibler, 2008; Lambert et al., 1960; Mendes, 2014; Oushiro, 2015) com o objetivo de verificar se falantes seriam "julgados" como "mais inteligentes", "mais escolarizados" e "mais formais" na presença de INFflex. Discutiram-se questões relacionadas ao desenho do experimento, tais como o desenvolvimento dos estímulos auditivos, manipulação dos áudios e aplicação dos questionários através de uma plataforma online. No que diz respeito aos resultados encontrados, uma vez que $91 \%$ dos 411 par- 
ticipantes que completaram a pesquisa têm ensino superior ou pós-gradução, não se podem tecer conclusões acerca de percepções por parte de menos ou não escolarizados. Esse fato, no entanto, permite conclusões a respeito das relações entre produção e percepção por parte dos participantes com alto nível de escolaridade: o que não é frequente na produção escrita dos acadêmicos, tal como o uso hipercorrigido de INFflex em complementos de modais, leva à percepção de que as "vozes" são menos 'competentes', ao passo que o que sim é frequente na produção escrita, tal como o emprego de INFflex em orações adverbiais $(40,16 \%, \mathrm{~N}=17045)$, é "julgado" com mais neutralidade no estudo de percepção. Verifica-se, portanto, uma correlação entre a frequência de uso das variantes em determinados contextos e as percepções sociolinguísticas. 


\section{Conclusão}

A partir da observação de empregos hipercorrigidos de INFflex na língua em uso e da alta taxa de INFflex em contextos opcionais que Canever (2012) encontrou em um corpus de 180 teses produzidas por alunos do curso de Letras da USP, esta pesquisa se propôs a: (i) analisar se o emprego da forma flexionada (INFflex) está aumentando nos três contextos sintáticos opcionais "originais" (Bossaglia, 2013a:27) - orações adverbiais, complementos oracionais de nomes e complementos oracionais de adjetivos - e (ii) investigar se valores sociais positivos, tais como o prestígio geralmente associado à concordância verbal em PB (Mendes \& Oushiro, 2015; Naro \& Scherre, 2013; Oushiro, 2015; Rubio \& Gonçalves, 2012), estariam sendo atribuídos a INFflex.

Após apresentar, no Capítulo 1, um panorama de diferentes perspectivas sobre emprego de INFflex em português, entre elas a visão de Maurer Jr. (1968: 100) acerca da tendência natural de expansão de INFflex para contextos sintáticos nos quais falantes venham a "sentir" que o infinitivo tem um agente, estabeleceram-se, no Capítulo 2, as bases teóricas deste estudo. A variação no emprego de INFflex em PB foi abordada com base nos pressupostos das teorias de língua baseadas no uso. Mais especificamente, alinhou-se à visão sociocognitivista delineada por Croft (2000), que propõe que tanto a frequência de uso quanto significados sociais são cruciais em processos de propagação de variantes linguísticas, tais como a expansão de INFflex para novos contextos sintáticos.

Para investigar a hipótese de que que INFflex estaria aumentando na 
escrita padrão, analisou-se quantitativamente o emprego de INFflex em um corpus formado por 1346 teses produzidas por alunos de diferentes unidades da USP entre 1995 e 2014, cuja arquitetura e construção foram discutidas no capítulo 3. Descreveu-se, ainda, no capítulo 3, o processo de revisão qualitativa dos 61.444 extraídos, que teve como objetivo verificar se todas as ocorrências de INFflex ou INF $\varnothing$ extraídas correspondiam, de fato, a dados de interesse para o estudo aqui desenvolvido.

Ao contrário do que se esperava, os resultados da análises indicam que INFflex não está aumentando nos contextos opcionais investigados. Verificouse, inclusive, uma leve tendência de queda, a cada ano, no emprego de INFflex em orações adverbiais e em complementos de adjetivos. As taxas de INFflex em complementos de substantivos, por sua vez, se mostraram estáveis ao longo dos 20 anos investigados.

Embora os resultados tenham contrariado a hipótese de aumento, eles revelam padrões interessantes. No que diz respeito à distribuição de INFflex de acordo com a área do conhecimento, por exemplo, nas orações adverbiais, verificaram-se maiores proporções de INFflex em teses da área de Humanas, tal como se esperava com base nos achados de Canever (2012). No geral, foram encontradas taxas altas de INFflex: em orações adverbiais antepostas à oração principal, com as preposições/locuções preposicionadas antes de, ao, após, depois de e por, e, tal como esperado, com o verbo ser. A respeito do verbo ser, atribui-se sua alta frequência de INFflex nos contextos opcionais "originais" (Bossaglia, 2013a) - em orações adverbiais, complementos de adjetivos e complementos de nomes - a um efeito de paralelismo linguístico: a presença dos particípios e predicativos plurais seguintes ao verbo estaria levando a mais INFflex (Scherre, 1998).

À luz da teorias de língua baseadas no uso (Bybee, 2006b, 2010; Croft, 2000; Langacker, 2000), a alta frequência de INFflex atestada no estudo aponta para um forte arraigamento de INFflex em certos contextos sintáticos, o que, em associação com uma valoração social positiva da variante flexionada, pode explicar a expansão de INFflex para novos contextos.

Quanto à investigação dos significados sociais associados à INFflex, o teste de percepção, apresentado no capítulo 5, revelou que, em contextos 
sintáticos nos quais o emprego de INFflex é considerado opcional, não houve diferença significativa na forma como as "vozes" foram julgadas; porém, em contextos sintáticos nos quais flexionar o infinitivo é considerado um "erro" do ponto de vista prescritivo, a presença de INFflex levou a percepções de menor "inteligência", menor "escolaridade" e menor "formalidade". Especificamente no caso dos contextos não padrão, verificou-se, ainda, um efeito significativo da variável Idade do participante: as percepções dos participantes mais jovens foram mais "neutras", ao passo que as respostas dos acima de 50 anos foram mais polarizadas: quanto mais velhos, mais negativamente julgaram versões com INFflex e mais positivamente versões com INFØ. Tais resultados sugerem que falantes mais jovens percebem de modo mais natural o que se considera "erro" na visão prescritivista.

Sendo assim, o fato de não ter se confirmado a hipótese de aumento na frequência de uso de INFflex nos contextos nos quais ele teria se originado (Bossaglia, 2013b) não nega a afirmação a respeito da tendência de expansão de INFflex para um número cada vez maior de contextos sintáticos. Além de ocorrências não padrão "inovadoras" serem atestadas na língua em uso, para os mais jovens, como sugerem os resultados de percepção, tais ocorrências já tendem a ser menos salientes, sugerindo, assim, que está em curso o processo de expansão presumido por Maurer Jr. (1968: 100). 


\section{Referências Bibliográficas}

Almeida, Napolão Mendes de. Gramática metódica da língua portuguesa. São Paulo: Saraiva, 46º ed., 2009 [1943].

Almeida, Napoleão Mendes. Dicionário de Questões Vernáculas. São Paulo: Caminho Suave, 1981.

Anthony, L. AntConc (Version 3.4.3) [Computer Software]. Tokyo, Japan: Waseda University., 2014.

URL http://www. laurenceanthony.net/

BAxter, Gareth \& Croft, William. "Modeling languange change across the lifespan: Individual trajectories in community change." Languange Variation and Change, vol. 28, 129-173, 2016.

Baxter, Gareth J., Blythe, Richard A., Croft, William \& McKane, Alan J. "Modeling language change: An evaluation of Trudgill's theory of the emerence of New Zealand English." Language Variation and Change, vol. 21(2), 2009.

BecharA, Evanildo. Moderna gramática portuguesa. Rio de Janeiro: Lucerna, 2004.

BecharA, Evanildo. Moderna gramática portuguesa. Rio de Janeiro: Nova Fronteira, $37^{\circ}$ ed., 2009.

Berber Sardinha, A. P. "O que é um corpus representativo?" DIRECT Papers 44, 2000. 
BIBER, Douglas. "Representativeness in corpus design." Literary and Linguistic Computing, vol. 8(4), 243-57, 1993.

BICK, Eckhard. The Parsing System 'Palavras' - Automatic Analysis of Portuguese in a Constraint Grammar Framework. Årthus: Åthus University Press, 2000.

- "Palavras, a constraint grammar-based parsing system for portuguese." In: SARdinha, Tony Berber \& DE Lurdes SÃo Bento FerREIRA, Thelma (Eds.), Working with Portuguese Corpora, pp. 279-302. London/New York:Bloomsburry Academic, 2014.

Blythe, Richard A. \& Croft, William. "Can a science-humanities collaboration be successful?" Adaptive Behavior, vol. 18, 12-20, 2010.

. "S-curves and the mechanisms of propagation in language change." Language, vol. 88(2), 269-304, 2012.

Boersma, Paul \& Weenink, David. Praat: doing phonetics by computer [Computer program]. Version 6.0.24, 2017.

URL http://www . praat.org/

Bossaglia, Giulia. Forme verbali flese e non-finite: Diacronia e sincronia dell'infinito portoghese. Ph.D. thesis, Università degli Studi Roma Tre, $2013 a$.

. "Inflected/non-inflected alternation in causative and perception constructions of conteporary european portuguese: A corpus-based study." Procedia: Social and Behavioral Sciences, vol. 95, 220-230, $2013 b$.

Boyland, Joyce Tang. "Hypercorrect pronoun case in english? cognitive processes that account for pronoun usage." In: ByBeE, J. \& Hopper, P. (Eds.), Frequency and the emergence of linguistic structure, pp. 383-404. Amsterdam and Philadelphia: John Benjamins., 2001.

Brandão, Silvia Figueiredo \& VieIRA, Silvia Rodrigues. "Concordância nominal e verbal: contribuições para o debate sobre o estatuto da variação 
em três variedades urbanas do português." Alfa, vol. 56(3), 1035-1064, 2012.

Bybee, Joan. Morphology: A study of the relation between meaning and form., 1985.

- Frequency of Use and the Organization of Language. Oxford: Oxford University Press, 2006a.

- "From usage to grammar: the mind's response to repetition." Language, vol. 82(4), 711-733, 2006b.

. Language, Usage and Cognition. Cambridge: Cambridge University., 2010.

Cabral, Grasiela de Souza. A concordância variável do infinitivo na escrita padrão. Master's thesis, Universidade Federal do Rio de Janeiro, 2006.

Cameron, Deborah. Verbal Hygiene, chap. On Verbal Hygiene., pp. 1-32. Routledge: New York., 1995.

CAmpbell-Kibler, Kathryn. "I'll be the judge of that: Diversity in social perceptions of (ing)." Language in Society, vol. 37(5), 637-659, 2008.

- "The nature of sociolinguistic perception." Language Variation and Change,, vol. 21(1), 2009.

CANEver, Fernanda. Evidências para um modelo de língua baseado no uso: o infinitivo flexionado em português brasileiro. Master's thesis, Universidade de São Paulo, 2012.

Cegalla, Domingos Paschoal. Novíssima Gramática da Língua Portuguesa. Companhia Editora Nacional, 48 ed., 2008.

Cezario, Maria Maura, Marques, Priscilla Mouta \& AbraÇAdo, Jussara. "Sociofuncionalismo." In: MollicA, Maria Cecilia \& Junior, Celso Ferrarezi (Eds.), Sociolinguística, sociolinguísticas, pp. 45-61. São Paulo : Editora Contexto, 2016. 
Cipro Neto, Pasquale \& Infante, Ulisses. Gramática da Língua Portuguesa. São Paulo: Scipione, 3 ed., 2010.

Croft, William. Explaining language change: an evolutionary approach. Harlow, Essex: Longman., 2000.

Cunha, Celso \& Cintra, Lindley. Nova gramática do português contemporâneo. Rio de Janeiro: Lexikon, 6 ed., 2013.

Duarte, Maria Eugênia Lamoglia. A perda do princpio "Evite Pronome" no português brasileiro. Ph.D. thesis, Unicamp, 1995.

DuBois, John W. "Competing motivations." In: Haiman, John (Ed.), Inconicity in Syntax. Amsterdam : John Benjamins, 1985.

ECKERT, Penelope. "Variation, convention, and social meaning." Paper Presented at the Annual Meeting of the Linguistic Society of America Oakland CA, 2005.

- "Variation and the indexical field." Journal of Sociolinguistics, vol. $12(4), 2008$.

- "Three waves of variation study: The emergence of meaning in the study of sociolinguistic variation." Annual Review of Anthropology, vol. 41, 87-100, 2012.

Efroymson, M. A. "Multiple regression analysis." In: Ralston, A. \& WILF, H. S. (Eds.), Mathematical methods for digital computers. New York: Wiley, 1960.

FAsold, Ralph W. "The quiet demise of variable rules." American Speech, vol. 66(1), 3-21, 1991.

Ferrari, Lilian. "Sociolinguística cognitiva." In: MollicA, Maria Cecilia \& Junior, Celso Ferrarezi (Eds.), Sociolinguística, sociolinguísticas, pp. 135-144. São Paulo : Editora Contexto, 2016. 
Fitzmaurice, Garrett M., Laird, Nan M. \& Ware, James H. Applied longitudinal analysis. Wiley, 2 ed., 2011.

Giles, Howard \& Williams, Angie. "Accommodating hypercorrection: a communication model." Language and Communication, vol. 12(3/4), 343356, 1992.

GIVón, Talmy. "Isomorphism in the grammatical code. cognitive and biological considerations." Studies in Languange 15, pp. 85-114, 1991.

- Functionalism and Grammar. Amsterdam / Philadelphia: John Benjamins, 1995.

Gorski, Edair. "Variação no uso do infinitivo pessoal." Organon, vol. 14(2829), 95-113, 2000.

GrIES, Stefan. T. Quantitative corpus linguistics with $R$ : a practical introduction. Londres, Nova York: Routledge, Taylor e Francis Group., 2nd ed., 2013 .

GrIEs, Stefan Th. "What is corpus linguistics?" Language and Linguistics Compass, vol. 3, 1-7, 2009.

GuY, Gregory R. "Linking usage and grammar: Generative phonology, exemplar theory, and variable rules." Lingua, vol. 142, 57-65, 2014.

Haiman, John. "Iconic and economic motivation." Languange 59, pp. 781819, 1983.

Hull, David. Science as a Process: An Evolutionary Account of the Social and Conceptual Development of Science. Chicago, IL: Univ. Chicago Press, 1988.

Kemmer, Suzanne \& Israel, Michael. "Variation and the usage-based model." Chicago Linguistics Society:, vol. 30(Papers from Parasession on Variation and Linguistic Theory), 165-179, 1994. 
Krzywinski, Martin \& Altman, Naomi. "Visualizing samples with box plots." Nature Methods, vol. 11, 119-120, 2014.

LABOV, William. "Contraction, deletion, and inherent variability of the english copula." Language, vol. 45(4), 1969.

. Sociolinguistic Patterns, chap. Hypercorrection by the Lower Middle Class as a Factor in Linguistic Change, pp. 122-142. Philadelphia: University of Pennsylvania Press., 1972.

Labov, William, Ash, Sharon, Baranowski, Maciej, Nagy, Naomi, RAVindranath, Maya \& Weldon, Tracey. "Listeners' sensitivity to the frequency of sociolinguistic variables." In: FrIEsner, M. L. \& RAVINDRANath, M. (Eds.), Penn Working Papers in Linguistics: Selected Papers from NWAV 34 New York., vol. 12, 2006.

Lambert, W. E., Hodson, R. C., Gardner, R. C. \& Fillenbaum, S. "Evaluational reactions to spoken languanges." Journal of Abnormal and Social Psychology, vol. 60(1), 44-51, 1960.

LAngaCKer, Ronald. Foundations of Cognitive Grammar: Theoretical Prerequisites Stanford: Stanford University Press., vol. 1. Stanford: Stanford University Press., 1987.

—. "A usage-based model." In: RudzkA-Ostyn, Brygida (Ed.), Topics in Cognitive Linguistics, pp. 127-161. Amsterdam: John Benjamins, 1988.

. "A dynamic usage-based model." In: BArLOw, Michael \& KEMMER, Suzanne (Eds.), Usage-Based Models of Language. Stanford: CSLI Publications., 2000.

LAVANDERA, Beatriz R. "Where does the sociolinguistic variable stop?" Languange in Society, pp. 171-182, 1978.

Lima, Rocha. Gramática normativa da língua portuguesa. Rio de Janeiro: José Olímpio, $53^{\circ}$ ed., 2017 [1957]. 
Maurer JR., T.H. O infinito flexionado português: estudo históricodescritivo. Imprenta. São Paulo: Cia. Ed. Nacional, 1968.

McEnery, Tony, Xiao, Richard \& Nono, Yukio. Corpus-based languade studies: an advanced resource book, chap. Corpus representativeness and balance. London: Routeledge, 2005.

Mendes, Ronald Beline. "Gendered perceptions of noun agreement in brazilian portuguese." Revista Internacional de Linguística Iberoamericana, vol. 12(23), 93-108, 2014.

. "Difhthongized (en) and the indexation of femininity and paulistanity." Cadernos de Estudos Linguísticos, vol. 58(3), 425-444, 2016 a.

. "Nonstandard noun phrase agreement as an index of masculinity." In: Levon, Erez \& Mendes, Ronald Beline (Eds.), Languange, sexuality and power: studies in intersectional sociolinguistics. Oxford: Oxford University Press, $2016 b$.

Mendes, Ronald Beline \& Oushiro, Livia. "Variable number agreement in Brazilian Portuguese: An overview." Language and Linguistics Compass, vol. 9(9), 358-268, 2015.

Modesto, Marcello. "Infinitivos flexionados em português brasileiro e sua relevância para a teoria do controle." In: DA HoRA, Dermeval \& NEGRÃo, Esmeralda Vailati (Eds.), Estudos da linguagem: casamento entre temas e perspectivas, pp. 63-86. João Pessoa: Ideia/Editora Universitária, 2011.

Naro, Anthony J. \& Scherre, Maria Marta Pereira. "Variação e mudança linguística: fluxos e contrafluxos na comunidade de fala.", 1991.

- "Remodeling the age variable: Number concord in brazilian portuguese.", 2013.

NouguÉ, Carlos. Suma Gramatical da Língua Portuguesa: Gramática Geral e Avançada. São Paulo: É REALIZAÇOES, 2015. 
Oushiro, Livia. Identidade na Pluralidade. Avaliação, produção e percepção linguística na cidade de São Paulo. Ph.D. thesis, Universidade de São Paulo, 2015 .

Perini, Mario. Gramática do infinitivo português. Petrópolis: Vozes, 1977.

. Gramática descritiva do português. São Paulo: Ática, 4a ed., 2005 [1995].

Pierrehumbert, Janet. "Examplar dynamics: Word frequency, lenition and contrast." In: ByBee, Joan \& Hopper, Paulo (Eds.), Frequency and the emergence of Linguistic Structure, pp. 137-158. Amsterdam: John Benjamins, 2001.

Poplack, Shana \& Malvar, Elisabete. "Elucidating the transition period in linguistic change: The expression of the future in brazilian portuguese." Probus, vol. 19, 121-169, 2007.

R Team, Development Core. R: A Language and Environment for Statistical Computing. R Foundation for Statistical Computing, Vienna, Austria, 2017. URL http://www.R-project.org/

Rubio, Cássio Florêncio \& Gonçalves, Sebastião Carlos Leite. "A fala do interior paulista no cenário da sociolinguística brasileira: panorama da concordância verbal e da alternância pronominal." Alfa, vol. 56(3), 1003-1034, 2012.

SAID Ali, Manuel. Gramática Histórica da Língua Portuguesa. São Paulo: Melhoramentos, 6a ed., 1966.

—. Grammatica secundaria da língua portugueza. São Paulo: Companhia Melhoramentos, [s/d.].

Scherre, Maria Marta Pereira. "Paralelismo linguístico." Revista Estudos Linguísticos, vol. 7(2), 29-59, 1998.

Scherre, Maria Marta Pereira \& NAro, Anthony J. "Sociolinguistic correlates of negative evaluation: variable concord in rio de janeiro.", 2014. 
Scherre, Maria Marte Pereira \& NAro, Anthony J. "Mudança sem mudança: a concordância de número no potuguês brasileiro.", 2006.

ScIDA, Emily. The inflected infinitive in Romance languages. New York, London: Routledge, 2004.

Soriano, Larissa. Percepções sociofonéticas do (-r) em São Paulo. Master's thesis, Universidade de São Paulo, 2016.

VANDERSCHUERen, Clara. Infinitivo y sujeito en português y español. Un estudio empírico de los infinitivos adverbiales con sujeito explícito. Berlin: De Gruyter, 2013.

Vanderschueren, Clara \& De Cuypere, Ludovic. "The inflected/noninflected infinitive alternation in portuguese adverbial clauses: a corpus analysis." Language Sciences, vol. 41, 154-174, 2014.

Vanderschueren, Clara \& Diependaele, Kevind. "The portuguese inflected infinitive: an empirical approach." Corpus Linguistics and Linguistic Theory, vol. 9(1), 161-186, 2013.

Vendler, Zeno. "Verbs and times." The philosophical review, vol. 66(2), 143-160, 1957.

Vesterinen, Rainer. Subordinação adverbial - um estudo cognitivo sobre o infinitivo, o clítico SE e as formas verbais finitas em proposições adverbiais do Português Europeu. Ph.D. thesis, Stockholms University, 2006.

WALKER, James A. "Form, function, and frequency in phonological variation." In: LABov, William \& CACoullos, Rena Torres (Eds.), Languange variation and change, vol. 24, pp. 397-415. Cambridge University Press, 2012.

Woods, Anthony, Fletcher, Paul \& Hughes, Arthur. Statistics in language studies. Cambridge University Press, 1986. 


\section{Anexo A}

Tabela A1 Análise descritiva de INFflex de acordo com as variáveis independentes do estudo

\begin{tabular}{|c|c|c|c|c|c|c|}
\hline \multirow{2}{*}{ Variável } & & \multicolumn{2}{|c|}{ INFflex } & \multicolumn{2}{|c|}{ INFØ } & \multirow{2}{*}{$p^{1}$} \\
\hline & & $\mathbf{N}$ & $\%$ & $\mathbf{N}$ & $\%$ & \\
\hline \multirow{9}{*}{ Faculdade } & Farmácia & 299 & $34,21 \%$ & 575 & $65,79 \%$ & \multirow{9}{*}{0,000} \\
\hline & Fea & 1350 & $29,79 \%$ & 3181 & $70,21 \%$ & \\
\hline & Fflch & 1956 & $30,57 \%$ & 4443 & $69,43 \%$ & \\
\hline & Física & 433 & $43,39 \%$ & 565 & $56,61 \%$ & \\
\hline & Medicina & 443 & $31,53 \%$ & 962 & $68,47 \%$ & \\
\hline & Poli & 676 & $39,51 \%$ & 1035 & $60,49 \%$ & \\
\hline & Psicologia & 1722 & $31,61 \%$ & 3725 & $68,39 \%$ & \\
\hline & Quim & 320 & $34,08 \%$ & 619 & $65,92 \%$ & \\
\hline & Spubl & 862 & $32,64 \%$ & 1779 & $67,36 \%$ & \\
\hline \multirow{3}{*}{ Área } & Biológicas & 1604 & $32,60 \%$ & 3316 & $67,40 \%$ & \multirow{3}{*}{0,000} \\
\hline & Exatas & 1429 & $39,17 \%$ & 2219 & $60,83 \%$ & \\
\hline & Humanas & 5028 & $30,70 \%$ & 11349 & $69,30 \%$ & \\
\hline \multirow{2}{*}{ Sexo } & Feminino & 4143 & $30,95 \%$ & 9245 & $69,05 \%$ & \multirow{2}{*}{0,018} \\
\hline & Masculino & 3918 & $33,90 \%$ & 7639 & $66,10 \%$ & \\
\hline \multirow{2}{*}{ Pessoa verbal } & $1^{\mathrm{a}}$ Pessoa & 1056 & $27,51 \%$ & 2782 & $72,49 \%$ & \multirow{2}{*}{0,111} \\
\hline & $3^{\text {a }}$ Pessoa & 7005 & $33,19 \%$ & 14102 & $66,81 \%$ & \\
\hline \multirow{3}{*}{ Contexto sintático } & Adverbiais & 6846 & $40,16 \%$ & 10199 & $59,84 \%$ & \multirow{3}{*}{0,000} \\
\hline & Complementos adjetivos & 962 & $22,88 \%$ & 3243 & $77,12 \%$ & \\
\hline & Complementos nomes & 253 & $6,85 \%$ & 3442 & $93,15 \%$ & \\
\hline \multirow{2}{*}{ Verbo } & Outros verbos & 5028 & $23,10 \%$ & 16740 & $76,90 \%$ & \multirow{2}{*}{0,000} \\
\hline & Verbo ser & 3033 & $95,47 \%$ & 144 & $4,53 \%$ & \\
\hline
\end{tabular}

${ }^{1}$ Regressão Logística com efeitos mistos univariada 
Tabela A2 Análise descritiva da interação entre as variáveis Pessoa Verbal e Ano

\begin{tabular}{|c|c|c|c|c|c|c|}
\hline \multirow{2}{*}{ Ano } & \multirow{2}{*}{ Pessoa Verbal } & \multicolumn{2}{|c|}{ INFflex } & \multicolumn{2}{|c|}{ INFØ } & \multirow{2}{*}{$p^{1}$} \\
\hline & & $\mathbf{N}$ & $\%$ & $\mathbf{N}$ & $\%$ & \\
\hline \multirow{2}{*}{1995} & $1 \mathrm{PP}$ & 9 & $37,50 \%$ & 15 & $62,50 \%$ & \multirow{2}{*}{0,638} \\
\hline & $3 \mathrm{PP}$ & 47 & $36,70 \%$ & 81 & $63,30 \%$ & \\
\hline \multirow{2}{*}{1996} & $1 \mathrm{PP}$ & 20 & $23,30 \%$ & 66 & $76,70 \%$ & \multirow{2}{*}{0,467} \\
\hline & $3 \mathrm{PP}$ & 118 & $33,10 \%$ & 238 & $66,90 \%$ & \\
\hline \multirow{2}{*}{1997} & $1 \mathrm{PP}$ & 22 & $23,70 \%$ & 71 & $76,30 \%$ & \multirow{2}{*}{0,024} \\
\hline & $3 \mathrm{PP}$ & 224 & $37,90 \%$ & 367 & $62,10 \%$ & \\
\hline \multirow{2}{*}{1998} & $1 \mathrm{PP}$ & & $28,20 \%$ & 51 & $71,80 \%$ & \multirow{2}{*}{0,299} \\
\hline & $3 \mathrm{PP}$ & 231 & $39,20 \%$ & 358 & $60,80 \%$ & \\
\hline \multirow{2}{*}{1999} & $1 \mathrm{PP}$ & 24 & $20,70 \%$ & 92 & $79,30 \%$ & \multirow{2}{*}{0,049} \\
\hline & $3 \mathrm{PP}$ & 358 & $36,90 \%$ & 612 & $63,10 \%$ & \\
\hline \multirow{2}{*}{2000} & $1 \mathrm{PP}$ & 69 & $31,50 \%$ & 150 & $68,50 \%$ & \multirow{2}{*}{0,368} \\
\hline & $3 \mathrm{PP}$ & 377 & $32,60 \%$ & 779 & $67,40 \%$ & \\
\hline \multirow{2}{*}{2001} & $1 \mathrm{PP}$ & 78 & $33,50 \%$ & 155 & $66,50 \%$ & \multirow{2}{*}{0,084} \\
\hline & $3 \mathrm{PP}$ & 395 & $31,40 \%$ & 863 & $68,60 \%$ & \\
\hline \multirow{2}{*}{2002} & $1 \mathrm{PP}$ & & $17,30 \%$ & 148 & $82,70 \%$ & \multirow{2}{*}{0,108} \\
\hline & $3 \mathrm{PP}$ & 424 & $34,60 \%$ & 803 & $65,40 \%$ & \\
\hline \multirow{2}{*}{2003} & $1 \mathrm{PP}$ & 52 & $26,30 \%$ & 146 & $73,70 \%$ & \multirow{2}{*}{0,751} \\
\hline & $3 \mathrm{PP}$ & 341 & $33,20 \%$ & 685 & $66,80 \%$ & \\
\hline \multirow{2}{*}{2004} & $1 \mathrm{PP}$ & 53 & $26,40 \%$ & 148 & $73,60 \%$ & \multirow{2}{*}{0,238} \\
\hline & $3 \mathrm{PP}$ & 410 & $37,10 \%$ & 695 & $62,90 \%$ & \\
\hline 2005 & $1 \mathrm{PP}$ & 43 & $22,90 \%$ & 145 & $77,10 \%$ & 04 \\
\hline & $3 \mathrm{PP}$ & 463 & $37,00 \%$ & 787 & $63,00 \%$ & {$[0,431$} \\
\hline & $1 \mathrm{PP}$ & 68 & $26,90 \%$ & 185 & $73,10 \%$ & 0533 \\
\hline 2000 & $3 \mathrm{PP}$ & 388 & $31,80 \%$ & 831 & $68,20 \%$ & 0,533 \\
\hline 2007 & $1 \mathrm{PP}$ & 48 & $26,70 \%$ & 132 & $73,30 \%$ & 0.841 \\
\hline & $3 \mathrm{PP}$ & 347 & $30,30 \%$ & 798 & $69,70 \%$ & | \\
\hline 2008 & $1 \mathrm{PP}$ & & $21,80 \%$ & 165 & $78,20 \%$ & 0480 \\
\hline 2000 & $3 \mathrm{PP}$ & 371 & $31,10 \%$ & 823 & $68,90 \%$ & 0,480 \\
\hline 2009 & $1 \mathrm{PP}$ & 48 & $26,50 \%$ & 133 & $73,50 \%$ & 0518 \\
\hline 2009 & $3 \mathrm{PP}$ & 400 & $33,00 \%$ & 812 & $67,00 \%$ & ], \\
\hline 2010 & $1 \mathrm{PP}$ & 108 & $28,30 \%$ & 274 & $71,70 \%$ & 0540 \\
\hline 2010 & $3 \mathrm{PP}$ & 516 & $33,60 \%$ & 1018 & $66,40 \%$ & {$[0,349$} \\
\hline 2011 & $1 \mathrm{PP}$ & 135 & $42,20 \%$ & 185 & $57,80 \%$ & 0.863 \\
\hline 2011 & $3 \mathrm{PP}$ & 475 & $34,60 \%$ & 898 & $65,40 \%$ & {$[0,803$} \\
\hline 2012 & $1 \mathrm{PP}$ & & $20,70 \%$ & 130 & $79,30 \%$ & 0178 \\
\hline 2012 & $3 \mathrm{PP}$ & 333 & $27,10 \%$ & 898 & $72,90 \%$ & {$[0,170$} \\
\hline & $1 \mathrm{PP}$ & 77 & $28,20 \%$ & 196 & $71,80 \%$ & $0,0,0$ \\
\hline 2010 & $3 \mathrm{PP}$ & 406 & $31,00 \%$ & 903 & $69,00 \%$ & 0,0 \\
\hline & $1 \mathrm{PP}$ & & $26,70 \%$ & 195 & $73,30 \%$ & 0.971 \\
\hline 2014 & $3 \mathrm{PP}$ & 381 & $30,90 \%$ & 853 & $69,10 \%$ & {$[, 9 / 1$} \\
\hline
\end{tabular}

${ }^{1}$ Regressão Logística com efeitos mistos bivariada 
Tabela A3 Análise descritiva da interação entre as variáveis Verbo e Ano

\begin{tabular}{|c|c|c|c|c|c|c|}
\hline \multirow{2}{*}{ Ano } & \multirow{2}{*}{ Verbo } & \multicolumn{2}{|c|}{ INFflex } & \multicolumn{2}{|c|}{ INFØ } & \multirow{2}{*}{$p^{1}$} \\
\hline & & $\mathbf{N}$ & $\%$ & $\mathbf{N}$ & $\%$ & \\
\hline \multirow{2}{*}{1995} & Outros verbos & 38 & $28,80 \%$ & 94 & $71,20 \%$ & \multirow{2}{*}{0,000} \\
\hline & Verbo ser & 18 & $90,00 \%$ & 2 & $10,00 \%$ & \\
\hline \multirow{2}{*}{1996} & Outros verbos & 79 & $20,60 \%$ & 304 & $79,40 \%$ & \multirow{2}{*}{0,000} \\
\hline & Verbo ser & 59 & $100,00 \%$ & 0 & $0,00 \%$ & \\
\hline \multirow{2}{*}{1997} & Outros verbos & 154 & $26,40 \%$ & 429 & $73,60 \%$ & \multirow{2}{*}{0,000} \\
\hline & Verbo ser & 92 & $91,10 \%$ & 9 & $8,90 \%$ & \\
\hline \multirow{2}{*}{1998} & Outros verbos & 149 & $26,80 \%$ & 407 & $73,20 \%$ & \multirow{2}{*}{0,000} \\
\hline & Verbo ser & 102 & $98,10 \%$ & 2 & $1,90 \%$ & \\
\hline \multirow{2}{*}{1999} & Outros verbos & 228 & $24,80 \%$ & 693 & $75,20 \%$ & \multirow{2}{*}{0,000} \\
\hline & Verbo ser & 154 & $93,30 \%$ & 11 & $6,70 \%$ & \\
\hline \multirow{2}{*}{2000} & Outros verbos & 312 & $25,20 \%$ & 925 & $74,80 \%$ & \multirow{2}{*}{0,000} \\
\hline & Verbo ser & 134 & $97,10 \%$ & 4 & $2,90 \%$ & \\
\hline \multirow{2}{*}{2001} & Outros verbos & 303 & $23,10 \%$ & 1008 & $76,90 \%$ & \multirow{2}{*}{0,000} \\
\hline & Verbo ser & 170 & $94,40 \%$ & 10 & $5,60 \%$ & \\
\hline \multirow{2}{*}{2002} & Outros verbos & 268 & $22,20 \%$ & 941 & $77,80 \%$ & \multirow{2}{*}{0,000} \\
\hline & Verbo ser & 187 & $94,90 \%$ & 10 & $5,10 \%$ & \\
\hline \multirow{2}{*}{2003} & Outros verbos & 228 & $21,60 \%$ & 827 & $78,40 \%$ & \multirow{2}{*}{0,000} \\
\hline & Verbo ser & 165 & $97,60 \%$ & 4 & $2,40 \%$ & \\
\hline \multirow{2}{*}{2004} & Outros verbos & 279 & $25,00 \%$ & 836 & $75,00 \%$ & \multirow{2}{*}{0,000} \\
\hline & Verbo ser & 184 & $96,30 \%$ & 7 & $3,70 \%$ & \\
\hline 2 & & 316 & $25,50 \%$ & 924 & $74,50 \%$ & \\
\hline & Verbo ser & 190 & $96,00 \%$ & 8 & $4,00 \%$ & \\
\hline & Outros verbos & 292 & $22,40 \%$ & 1010 & $77,60 \%$ & \\
\hline & Verbo ser & 164 & $96,50 \%$ & 6 & $3,50 \%$ & 0,000 \\
\hline 2007 & Outros verbos & 221 & $19,40 \%$ & 921 & $80,60 \%$ & 0.00 \\
\hline & Verbo ser & 174 & $95,10 \%$ & 9 & $4,90 \%$ & \\
\hline & Outros verbos & 235 & $19,30 \%$ & 981 & $80,70 \%$ & \\
\hline & Verbo ser & 182 & $96,30 \%$ & 7 & $3,70 \%$ & \\
\hline & Outros verbos & 269 & $22,40 \%$ & 933 & $77,60 \%$ & 0 \\
\hline & Verbo ser & 179 & $93,70 \%$ & 12 & $6,30 \%$ & 0,000 \\
\hline & Outros verbos & 415 & $24,50 \%$ & 1280 & $75,50 \%$ & \\
\hline & Verbo ser & 209 & $94,60 \%$ & 12 & $5,40 \%$ & \\
\hline & Outros verbos & 437 & $28,90 \%$ & 1076 & $71,10 \%$ & \\
\hline & Verbo ser & 173 & $96,10 \%$ & 7 & $3,90 \%$ & 0,000 \\
\hline & Outros verbos & 218 & $17,60 \%$ & 1021 & $82,40 \%$ & \\
\hline & Verbo ser & 149 & $95,50 \%$ & 7 & $4,50 \%$ & ,000 \\
\hline & Outros verbos & 301 & $21,70 \%$ & 1087 & $78,30 \%$ & \\
\hline 2013 & Verbo ser & 182 & $93,80 \%$ & 12 & $6,20 \%$ & ,000 \\
\hline & Outros verbos & 286 & $21,50 \%$ & 1043 & $78,50 \%$ & \\
\hline & Verbo ser & 166 & $97,10 \%$ & 5 & $2,90 \%$ & 0,000 \\
\hline
\end{tabular}


Tabela A4 Análise descritiva da interação entre a variável Contexto Sintático e Ano

\begin{tabular}{|c|c|c|c|c|c|c|}
\hline \multirow{2}{*}{ Ano } & \multirow{2}{*}{ Contexto sintático } & \multicolumn{2}{|c|}{ INFflex } & \multicolumn{2}{|c|}{ INFØ } & \multirow{2}{*}{$p^{1}$} \\
\hline & & $\mathbf{N}$ & $\%$ & $\mathbf{N}$ & $\%$ & \\
\hline \multirow{3}{*}{1995} & Adverbiais & 48 & $44,00 \%$ & 61 & $56,00 \%$ & \multirow{3}{*}{0,030} \\
\hline & Complementos adjetivos & 7 & $24,10 \%$ & 22 & $75,90 \%$ & \\
\hline & Complementos nomes & 1 & $7,10 \%$ & 13 & $92,90 \%$ & \\
\hline \multirow{3}{*}{1996} & Adverbiais & 114 & $38,10 \%$ & 185 & $61,90 \%$ & \multirow{3}{*}{0,000} \\
\hline & Complementos adjetivos & 18 & $35,30 \%$ & 33 & $64,70 \%$ & \\
\hline & Complementos nomes & 6 & $6,50 \%$ & 86 & $93,50 \%$ & \\
\hline \multirow{3}{*}{1997} & Adverbiais & 204 & $45,80 \%$ & 241 & $54,20 \%$ & \multirow{3}{*}{0,000} \\
\hline & Complementos adjetivos & 39 & $24,50 \%$ & 120 & $75,50 \%$ & \\
\hline & Complementos nomes & 3 & $3,80 \%$ & 77 & $96,20 \%$ & \\
\hline \multirow{3}{*}{1998} & Adverbiais & 210 & $45,20 \%$ & 255 & $54,80 \%$ & \multirow{3}{*}{0,000} \\
\hline & Complementos adjetivos & 36 & $31,00 \%$ & 80 & $69,00 \%$ & \\
\hline & Complementos nomes & 5 & $6,30 \%$ & 74 & $93,70 \%$ & \\
\hline \multirow{3}{*}{1999} & Adverbiais & 321 & $41,90 \%$ & 446 & $58,10 \%$ & \multirow{3}{*}{0,000} \\
\hline & Complementos adjetivos & 43 & $31,90 \%$ & 92 & $68,10 \%$ & \\
\hline & Complementos nomes & 18 & $9,80 \%$ & 166 & $90,20 \%$ & \\
\hline \multirow{3}{*}{2000} & Adverbiais & 366 & $37,30 \%$ & 614 & $62,70 \%$ & \multirow{3}{*}{0,000} \\
\hline & Complementos adjetivos & 67 & $29,40 \%$ & 161 & $70,60 \%$ & \\
\hline & Complementos nomes & 13 & $7,80 \%$ & 154 & $92,20 \%$ & \\
\hline \multirow{3}{*}{2001} & Adverbiais & 406 & $38,90 \%$ & 637 & $61,10 \%$ & \multirow{3}{*}{0,000} \\
\hline & Complementos adjetivos & 49 & $27,20 \%$ & 131 & $72,80 \%$ & \\
\hline & Complementos nomes & 18 & $6,70 \%$ & 250 & $93,30 \%$ & \\
\hline \multirow{3}{*}{2002} & Adverbiais & 383 & $38,30 \%$ & 616 & $61,70 \%$ & \multirow{3}{*}{0,000} \\
\hline & Complementos adjetivos & 60 & $29,30 \%$ & 145 & $70,70 \%$ & \\
\hline & Complementos nomes & 12 & $5,90 \%$ & 190 & $94,10 \%$ & \\
\hline \multirow{3}{*}{2003} & Adverbiais & 322 & $39,80 \%$ & 488 & $60,20 \%$ & \\
\hline & Complementos adjetivos & 56 & $27,50 \%$ & 148 & $72,50 \%$ & 0,000 \\
\hline & Complementos nomes & 15 & $7,10 \%$ & 195 & $92,90 \%$ & \\
\hline & Adverbiais & 374 & $42,50 \%$ & 505 & $57,50 \%$ & \\
\hline 2004 & Complementos adjetivos & 72 & $32,40 \%$ & 150 & $67,60 \%$ & 0,000 \\
\hline & Complementos nomes & 17 & $8,30 \%$ & 188 & $91,70 \%$ & \\
\hline & Adverbiais & 419 & $42,50 \%$ & 568 & $57,50 \%$ & \\
\hline 2005 & Complementos adjetivos & 64 & $29,40 \%$ & 154 & $70,60 \%$ & 0,000 \\
\hline & Complementos nomes & 23 & $9,90 \%$ & 210 & $90,10 \%$ & \\
\hline & Adverbiais & 399 & $41,20 \%$ & 570 & $58,80 \%$ & \\
\hline 2006 & Complementos adjetivos & 38 & $16,20 \%$ & 196 & $83,80 \%$ & 0,000 \\
\hline & Complementos nomes & 19 & $7,10 \%$ & 250 & $92,90 \%$ & \\
\hline & Adverbiais & 338 & $38,60 \%$ & 537 & $61,40 \%$ & \\
\hline 2007 & Complementos adjetivos & 45 & $19,00 \%$ & 192 & $81,00 \%$ & 0,000 \\
\hline & Complementos nomes & 12 & $5,60 \%$ & 201 & $94,40 \%$ & \\
\hline & Adverbiais & 346 & $37,90 \%$ & 568 & $62,10 \%$ & \\
\hline 2008 & Complementos adjetivos & 56 & $20,70 \%$ & 214 & $79,30 \%$ & 0,000 \\
\hline & Complementos nomes & 15 & $6,80 \%$ & 206 & $93,20 \%$ & \\
\hline & Adverbiais & 379 & $40,60 \%$ & 554 & $59,40 \%$ & \\
\hline 2009 & Complementos adjetivos & 56 & $21,00 \%$ & 211 & $79,00 \%$ & 0,000 \\
\hline & Complementos nomes & 13 & $6,70 \%$ & 180 & $93,30 \%$ & \\
\hline
\end{tabular}




\begin{tabular}{|c|c|c|c|c|c|c|}
\hline \multirow{3}{*}{2010} & Adverbiais & 558 & $40,60 \%$ & 817 & $59,40 \%$ & \multirow{3}{*}{0,000} \\
\hline & Complementos adjetivos & 54 & $19,50 \%$ & 223 & $80,50 \%$ & \\
\hline & Complementos nomes & 12 & $4,50 \%$ & 252 & $95,50 \%$ & \\
\hline \multirow{3}{*}{2011} & Adverbiais & 555 & $45,50 \%$ & 664 & $54,50 \%$ & \multirow{3}{*}{0,000} \\
\hline & Complementos adjetivos & 42 & $13,70 \%$ & 265 & $86,30 \%$ & \\
\hline & Complementos nomes & 13 & $7,80 \%$ & 154 & $92,20 \%$ & \\
\hline \multirow{3}{*}{2012} & Adverbiais & 305 & $34,00 \%$ & 593 & $66,00 \%$ & \multirow{3}{*}{0,000} \\
\hline & Complementos adjetivos & 53 & $17,00 \%$ & 258 & $83,00 \%$ & \\
\hline & Complementos nomes & 9 & $4,80 \%$ & 177 & $95,20 \%$ & \\
\hline \multirow{3}{*}{2013} & Adverbiais & 401 & $38,20 \%$ & 649 & $61,80 \%$ & \multirow{3}{*}{0,000} \\
\hline & Complementos adjetivos & 61 & $22,40 \%$ & 211 & $77,60 \%$ & \\
\hline & Complementos nomes & 21 & $8,10 \%$ & 239 & $91,90 \%$ & \\
\hline \multirow{3}{*}{2014} & Adverbiais & 398 & $38,70 \%$ & 631 & $61,30 \%$ & \multirow{3}{*}{0,000} \\
\hline & Complementos adjetivos & 46 & $16,30 \%$ & 237 & $83,70 \%$ & \\
\hline & Complementos nomes & 8 & $4,30 \%$ & 180 & $95,70 \%$ & \\
\hline
\end{tabular}

${ }^{1}$ Regressão Logística com efeitos mistos bivariada 
Tabela A5 Análise descritiva da interação entre as variáveis Preposição e Posição: Orações adverbiais

\begin{tabular}{|c|c|c|c|c|c|c|}
\hline \multirow{2}{*}{ Posição } & \multirow{2}{*}{ Preposição } & \multicolumn{2}{|c|}{ INFflex } & \multicolumn{2}{|c|}{ INFØ } & \multirow{2}{*}{$p^{1}$} \\
\hline & & $\mathbf{N}$ & $\%$ & $\mathbf{N}$ & $\%$ & \\
\hline \multirow{7}{*}{ anteposta } & antes de & 113 & $98,30 \%$ & 2 & $1,70 \%$ & \multirow{7}{*}{0,020} \\
\hline & ao & 431 & $97,70 \%$ & 10 & $2,30 \%$ & \\
\hline & após & 70 & $98,60 \%$ & 1 & $1,40 \%$ & \\
\hline & depois de & 34 & $100,00 \%$ & 0 & $0,00 \%$ & \\
\hline & para & 390 & $93,10 \%$ & 29 & $6,90 \%$ & \\
\hline & por & 221 & $99,50 \%$ & 1 & $0,50 \%$ & \\
\hline & sem & 7 & $87,50 \%$ & 1 & $12,50 \%$ & \\
\hline \multirow{7}{*}{ intercalada } & antes de & 15 & $88,20 \%$ & 2 & $11,80 \%$ & \multirow{7}{*}{0,002} \\
\hline & ao & 567 & $88,90 \%$ & 71 & $11,10 \%$ & \\
\hline & após & 42 & $100,00 \%$ & 0 & $0,00 \%$ & \\
\hline & depois de & 13 & $92,90 \%$ & 1 & $7,10 \%$ & \\
\hline & para & 69 & $62,70 \%$ & 41 & $37,30 \%$ & \\
\hline & por & 181 & $95,30 \%$ & 9 & $4,70 \%$ & \\
\hline & sem & 10 & $76,90 \%$ & 3 & $23,10 \%$ & \\
\hline \multirow{7}{*}{ posposta } & antes de & 28 & $53,80 \%$ & 24 & $46,20 \%$ & \multirow{7}{*}{0,000} \\
\hline & ao & 224 & $58,80 \%$ & 157 & $41,20 \%$ & \\
\hline & após & 96 & $95,00 \%$ & 5 & $5,00 \%$ & \\
\hline & depois de & 8 & $80,00 \%$ & 2 & $20,00 \%$ & \\
\hline & para & 1975 & $18,60 \%$ & 8670 & $81,40 \%$ & \\
\hline & por & 2171 & $86,00 \%$ & 352 & $14,00 \%$ & \\
\hline & sem & 181 & $18,10 \%$ & 818 & $81,90 \%$ & \\
\hline
\end{tabular}




\section{Anexo B}

Essa moça/esse rapaz parece:

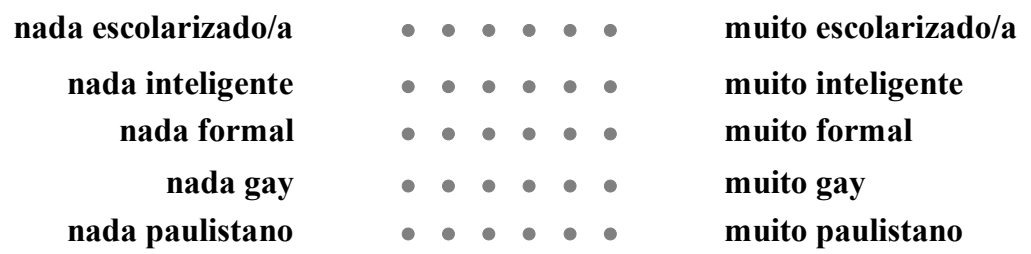

Qual você acha que é o nível de escolaridade dele/dela?
Fundamental 1
Fundamental 2
Médio
Superior

Qual você acha que é a faixa etária dele/dela?
adolescência
20 e poucos anos
30 e poucos anos
40 ou mais

A que classe econômica você acha que ele/ela pertence?

baixa média baixa média média alta alta

Figura 9 Questionário do teste de percepção 